\title{
Effects of global change during the 21st century on the nitrogen cycle
}

\author{
D. Fowler ${ }^{1}$, C. E. Steadman ${ }^{1,2}$, D. Stevenson ${ }^{2}$, M. Coyle ${ }^{1}$, R. M. Rees ${ }^{3}$, U. M. Skiba ${ }^{1}$, M. A. Sutton ${ }^{1}$, J. N. Cape ${ }^{1}$, \\ A. J. Dore ${ }^{1}$, M. Vieno ${ }^{1,2}$, D. Simpson ${ }^{4,12}$, S. Zaehle ${ }^{5}$, B. D. Stocker $^{6}$, M. Rinaldi ${ }^{7}$, M. C. Facchini ${ }^{7}$, C. R. Flechard ${ }^{8}$, \\ E. Nemitz ${ }^{1}$, M. Twigg ${ }^{1}$, J. W. Erisman ${ }^{9}$, K. Butterbach-Bahl ${ }^{10}$, and J. N. Galloway ${ }^{11}$ \\ ${ }^{1}$ Centre for Ecology \& Hydrology, Bush Estate, Penicuik, Midlothian, EH26 0QB, UK \\ ${ }^{2}$ School of GeoSciences, University of Edinburgh, Edinburgh, EH9 3FE, UK \\ ${ }^{3}$ Scotland's Rural College (SRUC), West Mains Road, Edinburgh, EH9 3JG, UK \\ ${ }^{4}$ Norwegian Meteorological Institute, EMEP-MSC-W, P.O. Box 43, 0313 Blindern, Norway \\ ${ }^{5}$ Biogeochemical Integration Department, Max Planck Institute for Biogeochemistry, Hans-Knöll-Strausse 10, \\ 07745 Jena, Germany \\ ${ }^{6}$ Imperial College, Department of Life Sciences, Silwood Park, Ascot, SL5 7PY, UK \\ ${ }^{7}$ ISAC-CNR, via P. Gobetti 101, 40129 Bologna, Italy \\ ${ }^{8}$ INRA, Agrocampus Ouest, UMR 1069 SAS, 35042 Rennes, France \\ ${ }^{9}$ Louis Bolk Institute, Hoofdstraat 24, 3972 LA, Driebergen, the Netherlands \\ ${ }^{10}$ Institute for Meteorology and Climate Research (IMK-IFU), Garmisch-Partenkirchen, Germany \\ ${ }^{11}$ Department of Environmental Sciences, University of Virginia, Charlottesville, VA 22904-4123, USA \\ ${ }^{12}$ Department of Earth and Space Sciences, Chalmers University of Technology, Gothenburg, Sweden
}

Correspondence to: D. Fowler (dfo@ceh.ac.uk)

Received: 25 November 2014 - Published in Atmos. Chem. Phys. Discuss.: 20 January 2015

Revised: 27 October 2015 - Accepted: 25 November 2015 - Published: 16 December 2015

\begin{abstract}
The global nitrogen (N) cycle at the beginning of the 21 st century has been shown to be strongly influenced by the inputs of reactive nitrogen $\left(\mathrm{N}_{\mathrm{r}}\right)$ from human activities, including combustion-related $\mathrm{NO}_{x}$, industrial and agricultural $\mathrm{N}$ fixation, estimated to be $220 \mathrm{Tg} \mathrm{N} \mathrm{yr}^{-1}$ in 2010, which is approximately equal to the sum of biological $\mathrm{N}$ fixation in unmanaged terrestrial and marine ecosystems. According to current projections, changes in climate and land use during the 21 st century will increase both biological and anthropogenic fixation, bringing the total to approximately $600 \mathrm{Tg} \mathrm{N} \mathrm{yr}^{-1}$ by around 2100 . The fraction contributed directly by human activities is unlikely to increase substantially if increases in nitrogen use efficiency in agriculture are achieved and control measures on combustion-related emissions implemented.

Some N-cycling processes emerge as particularly sensitive to climate change. One of the largest responses to climate in the processing of $\mathrm{N}_{\mathrm{r}}$ is the emission to the atmosphere of $\mathrm{NH}_{3}$, which is estimated to increase from $65 \mathrm{Tg} \mathrm{Nyr}^{-1}$ in
\end{abstract}

2008 to $93 \mathrm{Tg} \mathrm{Nyr}^{-1}$ in 2100 assuming a change in global surface temperature of $5^{\circ} \mathrm{C}$ in the absence of increased anthropogenic activity. With changes in emissions in response to increased demand for animal products the combined effect would be to increase $\mathrm{NH}_{3}$ emissions to $135 \mathrm{Tg} \mathrm{N} \mathrm{yr}^{-1}$. Another major change is the effect of climate changes on aerosol composition and specifically the increased sublimation of $\mathrm{NH}_{4} \mathrm{NO}_{3}$ close to the ground to form $\mathrm{HNO}_{3}$ and $\mathrm{NH}_{3}$ in a warmer climate, which deposit more rapidly to terrestrial surfaces than aerosols. Inorganic aerosols over the polluted regions especially in Europe and North America were dominated by $\left(\mathrm{NH}_{4}\right)_{2} \mathrm{SO}_{4}$ in the 1970 s to $1980 \mathrm{~s}$, and large reductions in emissions of $\mathrm{SO}_{2}$ have removed most of the $\mathrm{SO}_{4}^{2-}$ from the atmosphere in these regions. Inorganic aerosols from anthropogenic emissions are now dominated by $\mathrm{NH}_{4} \mathrm{NO}_{3}$, a volatile aerosol which contributes substantially to $\mathrm{PM}_{10}$ and human health effects globally as well as eutrophication and climate effects. The volatility of $\mathrm{NH}_{4} \mathrm{NO}_{3}$ and rapid dry deposition of the vapour phase dissociation 
products, $\mathrm{HNO}_{3}$ and $\mathrm{NH}_{3}$, is estimated to be reducing the transport distances, deposition footprints and inter-country exchange of $\mathrm{N}_{\mathrm{r}}$ in these regions.

There have been important policy initiatives on components of the global $\mathrm{N}$ cycle. These have been regional or country-based and have delivered substantial reductions of inputs of $\mathrm{N}_{\mathrm{r}}$ to sensitive soils, waters and the atmosphere. To date there have been no attempts to develop a global strategy to regulate human inputs to the nitrogen cycle. However, considering the magnitude of global $\mathrm{N}_{\mathrm{r}}$ use, potential future increases, and the very large leakage of $\mathrm{N}_{\mathrm{r}}$ in many forms to soils, waters and the atmosphere, international action is required. Current legislation will not deliver the scale of reductions globally for recovery from the effects of $\mathrm{N}_{\mathrm{r}}$ deposition on sensitive ecosystems, or a decline in $\mathrm{N}_{2} \mathrm{O}$ emissions to the global atmosphere. Such changes would require substantial improvements in nitrogen use efficiency across the global economy combined with optimization of transport and food consumption patterns. This would allow reductions in $\mathrm{N}_{\mathrm{r}}$ use, inputs to the atmosphere and deposition to sensitive ecosystems. Such changes would offer substantial economic and environmental co-benefits which could help motivate the necessary actions.

\section{Introduction}

While nitrogen is abundant, comprising $80 \%$ of the atmosphere, its form as molecular nitrogen $\mathrm{N}_{2}$ is largely unavailable to biota. Specialized organisms are able to fix nitrogen and transform it into compounds available for synthesis of amino acids and other metabolic products. Before human activities contributed to nitrogen fixation, the global nitrogen cycling in soils, vegetation, the atmosphere and oceans relied entirely on microbial biological fixation, plus a small contribution from lightning. Human activities began to substantially contribute to the global nitrogen cycle at the beginning of the 20th century through combustion, which creates fixed nitrogen as $\mathrm{NO}_{x}$, industrial $\mathrm{NH}_{3}$ production (by the HaberBosch process) and by growing nitrogen fixing crops. The global nitrogen $(\mathrm{N})$ cycle has been perturbed by human activity over the last 100 years with approximately two-thirds of the annual flux of reactive nitrogen $\left(\mathrm{N}_{\mathrm{r}}\right.$, which includes all compounds of nitrogen following fixation of molecular nitrogen $\mathrm{N}_{2}$ ) entering the atmosphere at the beginning of the $21 \mathrm{st}$ century being anthropogenic in origin (Galloway et al., 2004; Fowler et al., 2013). This has led to widespread negative consequences through directly contributing to radiative forcing of climate, reductions in biodiversity at regional scales in terrestrial ecosystems and in damage to human health through aerosols and ozone production (Erisman et al., 2013; Sutton et al., 2011). Human modification of the $\mathrm{N}$ cycle also has substantial benefits, through sustaining the food supply to a global human population of 7 billion and stimulating global
$\mathrm{CO}_{2}$ sequestration by terrestrial and marine ecosystems ( $\mathrm{Za}-$ ehle, 2013; Sutton et al., 2013b).

The damage by $\mathrm{N}_{\mathrm{r}}$ to ecosystems, human health and climate results from leakage of $\mathrm{N}$ compounds from its use in agriculture, industry and transport (Erisman et al., 2013). A particular feature of the $\mathrm{N}$ cycle is the combination of the large number of forms, both oxidized and reduced, in which $\mathrm{N}_{\mathrm{r}}$ exists, with biological and chemical transformations allowing the same emitted molecule of $\mathrm{N}_{\mathrm{r}}$ to take part in a series of effects, both negative and positive, before being transformed back to molecular nitrogen and returned to the atmospheric reservoir. This has been termed the nitrogen cascade (Galloway et al., 2003) and substantially complicates an assessment of the pathways and effects of $\mathrm{N}_{\mathrm{r}}$ in the environment.

The negative effects of human $\mathrm{N}$ fixation are substantial and have been estimated to be EUR 70-320 billion annually for Europe (Sutton et al., 2011; Brink et al., 2011). A comprehensive global assessment of the costs of human use of fixed $\mathrm{N}$ has yet to be made. However, the scale of European use, at $\sim 17 \mathrm{TgN}$ annually, represents only $8 \%$ of the total anthropogenic $\mathrm{N}_{\mathrm{r}}$ fixed annually $\left(220 \mathrm{Tg} \mathrm{N} \mathrm{yr}^{-1}\right)$. As the local hotspots of $\mathrm{N}_{\mathrm{r}}$ use in North America and especially in East and South Asia show values of emission and deposition similar to or larger than in Europe, it is likely that the global costs of human use of $\mathrm{N}_{\mathrm{r}}$ are therefore an order of magnitude greater than those for Europe. This would be consistent with a preliminary estimate of global damage costs associated with N pollution of USD 800 (200-2000) billion per year (Sutton et al., 2013b).

Recent analyses of the global $\mathrm{N}$ cycle have focused on the magnitude of current fluxes (Fowler et al., 2013), effects of human activity on the processes and effects on human health, climate and ecosystems, especially in the regional assessments in Europe (Sutton et al. 2011, 2013b) and in the United States of America (Davidson et al., 2012). The extensive conversions of $\mathrm{N}_{\mathrm{r}}$ in the environment mediated by biological and chemical processes are sensitive to environmental conditions and thus are likely to respond to changes in climate over coming decades. Thus the current global $\mathrm{N}$ cycle is likely to change, regardless of future changes in human activities or human intervention to regulate losses to the environment.

The likely responses of the exchanges of $\mathrm{N}_{\mathrm{r}}$ between and within the major global reservoirs in coming decades to changes in climate and land use have not been considered to date, and are the focus of this review.

Recent assessments of state of scientific understanding include 14 papers published by The Royal Society on the global nitrogen cycle (Philos. T. Roy. Soc. B, Volume 368, 2013). These relatively short papers focus on components of the global nitrogen cycle in the atmosphere, terrestrial marine and polar regions, and include a global overview (Fowler et al., 2013). The coverage is not encyclopaedic and the main focus is on terrestrial ecosystems and the atmosphere. The 
effects of climate changes in the 21 st century are not treated in detail within these papers.

The potential impacts of changes in climate and land use on the global nitrogen cycle are considerable in both the range and magnitude of effects. The processes which regulate transfers between the atmosphere and terrestrial and marine reservoirs are generally sensitive to aspects of climate that are expected to change, including temperature, absolute humidity and precipitation (Sutton et al., 2013b). Many of the major transfers are mediated by biological processes, especially microbiological transformations, which are very sensitive to changes in climate. The exchange fluxes of $\mathrm{N}_{\mathrm{r}}$ compounds at the Earth's surface, including emission and deposition, are regulated by a combination of atmospheric transfer and surface reactions and biological regulation through stomatal exchange and soil microbiology. These processes therefore include physical, chemical and biological interactions combining to regulate the overall process. Most of the components of the pathway are sensitive to climate, and while the response of some components to specific changes in the environment may be predicted, the overall process relies on measurements to constrain the potential range of effects (Fowler et al., 2009; Monks et al., 2009).

Some of the effects appear straightforward, such as increases in emission fluxes of nitric oxide (NO) from soils and ammonia $\left(\mathrm{NH}_{3}\right)$ from vegetation with temperature, but when the full range of expected changes in climate and the number and phase in which the $\mathrm{N}_{\mathrm{r}}$ compounds reside are included, the responses become complex and harder to quantify. To consider the whole $\mathrm{N}$ cycle and interactions with climate and land-use change requires a coupled global climate and N-cycle model, which to date has not been achieved. While parts of the biogeochemistry have been incorporated in global climate models, especially those linked to ozone chemistry and emissions of oxidized N (Stevenson et al., 2006), many of the interactions of reduced nitrogen compounds have yet to be included (Sutton et al., 2013b). In the absence of global modelling needed to quantify the interactions, there have been a number of model investigations at regional scales. There have also been modelling studies of interactions between the carbon and $\mathrm{N}$ cycles which provide useful insight to biogeochemical interactions (Zaehle, 2013).

This paper explores current knowledge of the sensitivity of biological nitrogen fixation, emissions, atmospheric processing and removal of $\mathrm{N}_{\mathrm{r}}$ compounds to changes in climate and land use, defined here as follows:

a. Climate change refers to the change of the primarily environmental drivers temperature and rainfall (amount, frequency, seasonal distribution), both affecting soil environmental conditions but also site and landscape hydrology, vegetation cover and substrate supply. Land use is also influenced, since farmers will adapt land use and land management as climate changes (Kicklighter et al., 2014). b. Land-use change refers to changes in vegetation cover, land use and management resulting in changes in substrate supply to the soil microbial community, but also triggers changes in soil and catchment hydrology. Policy and economic drivers also influence the uptake of measures aimed at promoting mitigation in the agricultural sector (MacLeod et al., 2010).

c. Atmospheric composition change is mainly due to rising $\mathrm{CO}_{2}$ concentrations, resulting in reductions in plant transpiration and increasing levels of soil moisture (e.g. Long et al., 2004), but also to changes in regional $\mathrm{O}_{3}$ concentrations - affecting plant performance and, thus, e.g. plant litter production or transpiration - and/or atmospheric deposition of reactive nitrogen (Sutton et al., 2011), which not only is an additional $\mathrm{N}_{\mathrm{r}}$ source for soil microbial processes but also drives forest $\mathrm{C}$ sequestration and changes in soil $\mathrm{C}$ and $\mathrm{N}$ stocks (De Vries et al., 2014).

The focus is on responses of the flow of nitrogen through terrestrial and marine ecosystems and the atmosphere to changes this century and includes new modelling and analysis as well as the published literature. Consequences for human health, ecosystems and food production of these likely responses are briefly considered.

The structure of the review follows the pathway from fixation of atmospheric nitrogen, by both biological and industrial processes to emission of gaseous $\mathrm{N}_{\mathrm{r}}$ compounds into the atmosphere and removal by dry and wet deposition. Interactions between global nitrogen and carbon cycles are included as they represent key areas of development of Earth system models and are a focus of wider academic interest in the global nitrogen cycle.

Some components of the nitrogen cycle are well supported by recent literature and extensive measurements, as in the case of surface-atmosphere exchange processes, and oxidized nitrogen compounds in the atmosphere, while others are poorly supported by measurements and recent research. This variability in knowledge leads to different approaches in the sections of the paper, concentrating on those components which have been subject to recent publications, or new modelling, specifically developed for this paper.

The review concludes with a brief discussion of the policy implications of climate-nitrogen cycle interactions, as this is an important driver of the research agenda and provides context, and has been the subject of several recent publications (Sutton et al., 2011, 2013a).

\section{Biological nitrogen fixation}

Biological nitrogen fixation (BNF) is currently estimated to provide a global annual input of $258 \mathrm{Tg} \mathrm{N} \mathrm{yr}^{-1}$ to the biosphere (Fowler et al., 2013) making it the largest single global input of $\mathrm{N}_{\mathrm{r}}$, although there are significant uncertain- 
ties about the magnitude and spatial distribution of fluxes (Fig. 1). If we assume that the global $\mathrm{N}$ cycle was in an approximate equilibrium prior to industrialization, BNF would have been balanced by the reductive processes of denitrification returning molecular nitrogen $\left(\mathrm{N}_{2}\right)$ to the atmosphere, with estimates of around $260 \mathrm{Tg} \mathrm{N} \mathrm{yr}^{-1}$ arising from terrestrial and oceanic sources (Galloway et al., 2004). The process of fixation is undertaken by a very limited range of highly specialized microorganisms that share an ability to use the nitrogenase enzyme to split the triple bond present in atmospheric $\mathrm{N}_{2}$ and combine it with hydrogen to produce a source of $\mathrm{N}_{\mathrm{r}}$. Although the process is highly energy demanding, it is performed at ambient temperature and pressure unlike the industrial Haber-Bosch process that requires the reactants to be combined in the presence of an iron catalyst at between 300 and $500^{\circ} \mathrm{C}$ in a reaction vessel at $20 \mathrm{MPa}$. Two main groups of organisms are responsible: free-living bacteria and algae (which are widespread in freshwater, oceans and uncultivated soils and often form mutualistic associations with a range of plant species) and symbiotic bacteria (mostly belonging to the genus Rhizobium) which form symbiotic associations with the roots of plants (mostly belonging to the family Leguminosae).

\subsection{Terrestrial nitrogen fixation}

In terrestrial environments, a wide diversity of both symbiotic and free-living $\mathrm{N}$ fixers contribute to BNF in nonagricultural soils, but a lack of measurements results in large uncertainties in reported values. A meta-analysis of published data compiled from a large number of individual measurements of $\mathrm{N}$ fixation carried out in diverse ecosystems reported an average annual global flux of $195 \mathrm{Tg} \mathrm{N}$ with a range of 100-290 (Cleveland et al., 1999), although this was later revised down to $128 \mathrm{Tg}$ (Galloway et al., 2004). It is thought that tropical environments are particularly important in contributing to terrestrial BNF, although these areas are associated with the least measurements. Recent measurements of BNF by methanotrophs in pristine peatland at high latitude by Vile et al. (2014) suggest appreciable fixation in these environments which have not been included in global estimates to date. Using net carbon uptake methods, Porada et al. (2014) and Elbert et al. (2012) also suggest significant contributions to global nitrogen fixation from lichens and bryophytes.

Using an N-balance approach in which the global $\mathrm{N}$ cycle is assumed to be in steady state, BNF can be estimated as the difference between inputs and outputs of $\mathrm{N}$ within a global context. This approach has suggested that preindustrial terrestrial BNF in natural ecosystems was only $44 \mathrm{Tg} \mathrm{N} \mathrm{yr}^{-1}$ (Vitousek et al., 2013); however, such a small value questions whether current rates of natural BNF reported by Cleveland and others from upscaling may have been overestimated. The recent estimate of BNF in natural terrestrial ecosystems of $58 \mathrm{Tg} \mathrm{N}$ annually by Vitousek et al. (2013) is sub- stantially smaller than other recent syntheses of the literature, which are generally in excess of $100 \mathrm{Tg} \mathrm{N}$ annually. The most recent measurements of BNF in peatlands, which, although representing $3 \%$ of the world's land surface, contain approximately $25 \%$ of the world's soil carbon, suggest an additional source in these regions in the range of 4.8 to $62.3 \mathrm{~kg} \mathrm{Nha}^{-1}$ annually and a mean value of $25.8 \mathrm{~kg} \mathrm{Nha}^{-1}$ annually (Vile et al., 2014). Net carbon uptake by lichens and bryophytes has also been used to estimate nitrogen requirement and indirectly nitrogen fixation by Porada et al. (2014), also suggesting a significant contribution to global $\mathrm{N}$ fixation by these plant communities. Given these new measurementbased values for extensive ecosystems, the value for global BNF in natural ecosystems seems unlikely to be smaller than $100 \mathrm{Tg} \mathrm{N}$ annually, and the value proposed by Galloway et al. (2004) of $128 \mathrm{Tg} \mathrm{N} \mathrm{yr}^{-1}$ is used here for 2010 .

Biological $\mathrm{N}$ fixation provides a large input of fixed $\mathrm{N}$ to agricultural systems. Prior to the development of synthetic fertilizers at the beginning of the 20th century, most of the $\mathrm{N}$ used to produce crops and livestock would have been derived from this source. The current input is estimated to be approximately $60 \mathrm{Tg} \mathrm{N} \mathrm{yr}^{-1}$, taken as the central value in the range $50-70 \mathrm{Tg} \mathrm{yr}^{-1}$ from Herridge et al. (2008). This value is divided mainly between the grain legumes (peas and beans) and forage legumes (such as clover and alfalfa) contributing 21 and $19 \mathrm{Tg} \mathrm{yr}^{-1}$ respectively (Herridge et al., 2008). Estimates of BNF by the grain legumes are generally considered to be more reliable than those from forage crops since comprehensive records of the former are maintained by FAO (FAO, 2012). Other minor inputs of $\mathrm{N}$ by BNF in agriculture include symbiotic $\mathrm{N}$ fixation from tropical savannas used for grazing (14 Tg), free-living micro-organisms associated with rice paddies $(5 \mathrm{Tg})$ and sugar cane $(0.5 \mathrm{Tg})$.

During the 20th century, there has been a rapid growth in the cultivation of leguminous crops contributing to an increase in associated BNF (Galloway et al., 2004). Future growth of legume crops will be constrained by the land area available to agriculture, and increases in production are most likely to occur when legumes are grown in place of other species. Emissions of nitrous oxide $\left(\mathrm{N}_{2} \mathrm{O}\right)$ resulting from the growth of legume crops are generally small by comparison with other crops, and the IPCC guidelines on greenhouse gas reporting assume that the $\mathrm{N}$ input resulting from legume production is not associated with any $\mathrm{N}_{2} \mathrm{O}$ emissions (IPCC, 2006). For this reason, increases in legume cultivation have been promoted as an opportunity to reduce $\mathrm{N}_{2} \mathrm{O}$ emissions from agricultural systems by reducing emission intensity of fixed $\mathrm{N}$ inputs to agricultural systems (Luscher et al., 2014). Legumes also continue to provide the main source of $\mathrm{N}$ input to low-input agricultural systems and organic farming globally. 


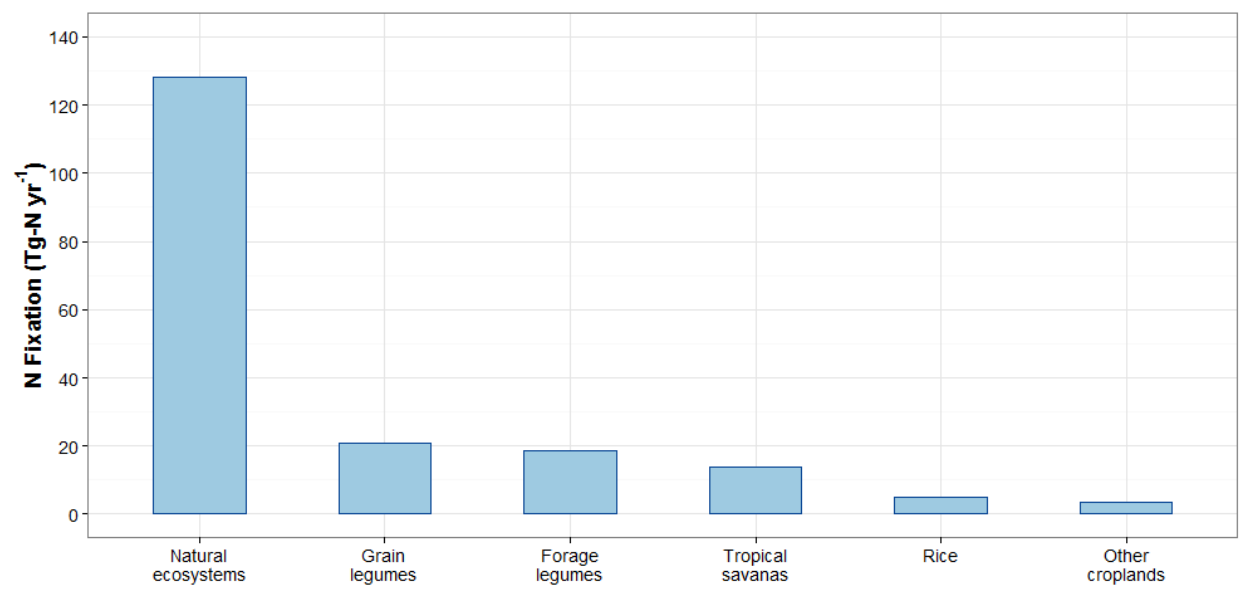

Figure 1. Summary of estimated global terrestrial contributions to biological $\mathrm{N}$ fixation in 2000. Values in $\mathrm{Tg} \mathrm{N}^{-1}$ (based on Table 1 and activity projections).

\subsubsection{Effects of climate change on terrestrial biological nitrogen fixation (BNF)}

Biological $\mathrm{N}$ fixation associated with non-agricultural ecosystems is susceptible to changes in environmental conditions. A framework for understanding the environmental controls determining the rates of BNF in the biosphere has been proposed in which there is a coupling between $\mathrm{N}, \mathrm{C}$ and phosphorus (P) cycling (Houlton et al., 2008; Vitousek et al., 2002). Free-living and symbiotic organisms with the potential to fix $\mathrm{N}$ are at a selective advantage in environments with low $\mathrm{P}$ availability; however, the high energy costs of BNF require adequate supplies of available fixed $\mathrm{C}$. The temperature sensitivity of the nitrogenase enzyme responsible for the fixation process has been clearly demonstrated in a global meta-analysis of fixation rates across dominant terrestrial biomes; the optimal temperature for fixation was found to be $25.2^{\circ} \mathrm{C}$ with a very sharp decline in rates of fixation below $5^{\circ} \mathrm{C}$ and above $40^{\circ} \mathrm{C}$ (Houlton et al., 2008). Projected global increases in temperature are therefore likely to be associated with increases in BNF, providing that sufficient water is available to maintain net primary productivity. However, other environmental changes may counteract increases resulting from climate change. The process of BNF is often down-regulated by the presence of fixed N. Agricultural experiments have consistently shown lower rates of fixation in the presence of high concentrations of soil mineral $\mathrm{N}$ and organic N inputs (Ledgard and Steele 1992). The biological responses to temperature are generally positive, and $Q_{10}$ values (defined as the response factor for a $10^{\circ} \mathrm{C}$ temperature change) are often in the range 1.5 to 3 for soil temperatures between 5 and $25^{\circ} \mathrm{C}$, outside which non-linearities are common. Taking a $Q_{10}$ of 2 and temperature increases by 2100 of $4{ }^{\circ} \mathrm{C}$, which appear probable (IPCC, 2013), the natural, terrestrial $\mathrm{BNF}$ in 2100 is likely to be $170 \mathrm{Tg} \mathrm{N}$ annually.
Adopting a similar approach for agricultural systems, BNF for agriculture in 2100 would be $79 \mathrm{Tg}-\mathrm{N}$ annually.

\subsection{Marine biological nitrogen fixation in the 21st century}

Marine biological $\mathrm{N}$ fixation is performed by a diverse range of diazotrophs in plankton, microbial mat communities, sea grasses, coral reefs and sea sediments. Cyanobacteria of the genus Trichodesmium have been particularly well studied due to their prevalence and their formation of large blooms. Biological N-fixation rates vary by species and can be limited by temperature, light, oxygen, salinity, molybdenum, iron and $P$.

Estimates have been made for global $\mathrm{N}$ fixation in the oceans, both by extrapolating from biological measurements and by modelling the biogeochemistry. Recent reviews include Carpenter and Capone (2008), Moore et al. (2013) and Voss et al. (2013).

Future changes to the ocean including increasing carbon dioxide $\left(\mathrm{CO}_{2}\right)$ concentrations, increasing stratification, and increasing temperatures will likely result in an increase in marine nitrogen fixation. Nitrogen fixation leads to an increase in bioavailable $\mathrm{N}$ present in the form of ammonium and dissolved organic N (Mulholland et al., 2006). An increase in $\mathrm{N}_{2}$ fixation would therefore lead to an increase in the amount of $\mathrm{N}_{\mathrm{r}}$ available to enable further processes in the $\mathrm{N}$ cycle.

The objective of this section is to characterize the current state of knowledge on marine BNF and the likely effects of changes in climate on marine BNF in the 21 st century.

\section{Light}

Nitrogen fixers have strong preferences for specific light conditions. Depending upon the species, either light or darkness is required. Many non-heterocystous cyanobacteria fix nitro- 
Table 1. Global terrestrial contributions to biological $\mathrm{N}$ fixation in 2000 . Values in $\mathrm{Tg} \mathrm{N}$ per year with the range of estimates in brackets.

\begin{tabular}{|c|c|c|c|}
\hline $\begin{array}{l}\text { Agricultural system } \\
\text { or ecosystem }\end{array}$ & Organism & $\begin{array}{l}\text { Annual } \mathrm{N} \text { fixation } \\
\left(\mathrm{Tg} \mathrm{gr}^{-1}\right) \text { and range }\end{array}$ & References \\
\hline Grain legumes & Legume rhizobia & $21(10-21)$ & Herridge et al. (2008), Smil (1999) \\
\hline Forage legumes & Legume rhizobia & $18.5(12-25)$ & Herridge et al. (2008) \\
\hline Rice & Azolla & $5(4-6)$ & Herridge et al. (2008), Smil (1999) \\
\hline Other croplands & Endophytic and free-living bacteria & 3.5 & Herridge et al. (2008) \\
\hline Tropical savannas (used for agriculture) & Endophytic and free-living bacteria & $12(5-42)$ & $\begin{array}{l}\text { Cleveland et al. (1999), } \\
\text { Herridge et al. (2008) }\end{array}$ \\
\hline Non-agricultural ecosystems & Legume rhizobia and free-living bacteria and algae & $128(44-290)$ & $\begin{array}{l}\text { Cleveland et al. (1999), } \\
\text { Galloway et al. (2004), } \\
\text { Vitousek et al. (2013) }\end{array}$ \\
\hline
\end{tabular}

gen at night; however, members of the genus Trichodesmium fix $\mathrm{N}$ only in the presence of light (Capone et al., 1997). Trichodesmium are therefore present at the surface of the ocean, and maximum fixation occurs at midday (Carpenter and Capone, 2008). Light sensitive diazotrophs like Trichodesmium could be affected by decreasing solar irradiance due to the presence of more clouds, resulting in a decrease in $\mathrm{N}_{2}$ fixation.

\section{Temperature}

Enzyme activity generally increases with temperature, and this is true for nitrogen-fixing enzymes (nitrogenases). Staal et al. (2003) found that on short timescales, three strains of cyanobacteria exhibited a $Q_{10}$ ranging from 1.08 to 4.72 . Trichodesmium exhibited a $Q_{10}$ of 1.12 for $\mathrm{N}_{2}$ fixation in darkness from 20 to $35^{\circ} \mathrm{C}$, and a $Q_{10}$ of 2.06 from 15 to $20^{\circ} \mathrm{C}$. In the presence of light, Trichodesmium exhibited a $Q_{10}$ of 1.64 for $15-20^{\circ} \mathrm{C}$, and 1.84 for $20-35^{\circ} \mathrm{C}$. Fu et al. (2014) exposed strains of Trichodesmium and Crocosphaera to varying temperatures in the laboratory and found maximum $\mathrm{N}$ fixation to occur between $24-28$ and $28-30^{\circ} \mathrm{C}$, respectively.

Increasing temperatures will likely cause the rate of $\mathrm{N}$ fixation to increase, both because enzyme activity increases at higher temperatures and because the increase in sea surface temperatures will lead to an expansion of habitat suitable for diazotrophs (Hutchins et al., 2009). Boyd and Doney (2002) predict that habitat expansion will lead to an increase in $\mathrm{N}$ fixation of $27 \%$.

Until recently, there was little evidence of marine diazotrophic activity in the cooler waters present at high latitudes $\left(>50^{\circ}\right)$ (Carpenter and Capone, 2008). A recent study found substantial $\mathrm{N}$ fixation in the surface of the Canadian Arctic (Blais et al., 2012). These recent discoveries suggest diazotrophs may be fixing $\mathrm{N}$ in areas previously thought to be too cold for large levels of BNF.

\section{Oxygen}

Most nitrogen-fixing enzymes are inactivated by oxygen. Diazotrophs generally deal with this by performing $\mathrm{N}$ fixation either at night to avoid oxygen produced during photosynthesis, or within thick-walled cells called heterocysts, which maintain a localized anaerobic environment.

Nitrogen fixation has generally not been considered in oxygen minimum zone (OMZ) systems (Carpenter and Capone, 2008). Due to the removal of $\mathrm{N}_{\mathrm{r}}$ by denitrification and anaerobic ammonium oxidation, OMZs have low concentrations of $\mathrm{N}_{\mathrm{r}}$ relative to $\mathrm{P}$ (Canfield, 2006), and the conditions in these sites may be suitable for $\mathrm{N}$ fixation. Modelling efforts have considered $\mathrm{N}_{2}$ fixation in OMZs (Canfield, 2006; Moore and Doney, 2007).

Expanding OMZs may increase areas conducive to denitrification and anaerobic ammonium oxidation. If nitrogenfixing bacteria exist in balance with denitrification (Deutsch et al., 2007), then the increase in denitrification may lead to a corresponding increase in $\mathrm{N}_{2}$ fixation. Oxygen minimum zones may also lead to an increase in the release of trace metals (Noble et al., 2012) and P from sediments, which could stimulate increased $\mathrm{N}_{2}$ fixation.

\section{Salinity}

Diazotrophs may be able to live in a variety of saline conditions. For example, a Trichodesmium isolate was found to grow over a salinity range of $22-43$ psu, but maximum growth and nitrogenase activity occurred over a narrow range of 33-37 psu (Fu and Bell, 2003). Changes in salinity are not expected to have a large effect on $\mathrm{N}$ fixation.

\section{Trace metals and phosphorus}

Nitrogenase requires both iron and molybdenum. Nitrogen fixation is limited by iron in approximately $35-75 \%$ of the oceans, globally (Moore et al., 2002; Berman-Frank et al., 2001). Molybdenum is generally not growth limiting (Paerl et al., 1987; Paulsen et al., 1991) as it is readily present in seawater. However, sulfate may inhibit the uptake of molybdenum, because sulfate is also present and is stereochemically similar to molybdate (Howarth and Cole, 1985; Marino et al., 2003). 
Phosphorus is an essential nutrient; however, surface waters today are thought to be more limited by $\mathrm{N}$ rather than $\mathrm{P}$ over much of the oceans (Moore and Doney, 2007). Approximately $4 \%$ of the world oceans are limited by P (Moore et al., 2002).

Aeolian dust deposition leads to higher levels of iron reaching the subtropical North Atlantic Ocean. Under present-day conditions, $\mathrm{P}$ may therefore be more limiting for diazotrophs in the North Atlantic, and iron may be more limiting in the North Pacific Ocean (Prospero and Lamb, 2003). Climate change may affect the transport of aeolian dust. If drier areas become drier, and/or wind speed increases, the amount of dust transported from continents to the oceans may increase, which would increase nitrogen fixation in areas limited by iron. However, if the areas that receive the dust are limited by other nutrients, then the increase in dust transport would have little effect.

\section{Stratification}

A strengthening of ocean stratification may lead to a decrease in nutrient upwelling, which would in turn lead to a shortage of $\mathrm{N}$ at the surface, which may cause an expansion of nitrogen-limited subtropical gyres (Sarmiento et al., 2004) and possibly encourage an increased rate of $\mathrm{N}$ fixation.

\section{Carbon dioxide}

Both model and laboratory studies of Trichodesmium isolates have shown an increase in $\mathrm{N}_{2}$ fixation associated with increasing atmospheric $\mathrm{CO}_{2}$ concentrations. Studies with Trichodesmium cultures have reported a range of measurements for the increase in $\mathrm{N}_{2}$ fixation associated with increasing $\mathrm{CO}_{2}$ concentrations from present-day levels (375-380 ppm) to projected 2100 levels ( $\sim 750-1000 \mathrm{ppm})$. Studies have reported an increase in rates of around 35-65\% (Hutchins et al., 2007; Barcelos e Ramos et al., 2007; Kranz et al., 2009), and as high as 100-121\% (Hutchins et al., 2007; Levitan et al., 2007). Barcelos e Ramos et al. (2007) predicted that $\mathrm{N}_{2}$-fixation rates for Trichodesmium would increase by $50 \%$ from $60-85 \mathrm{Tg} \mathrm{N} \mathrm{yr}^{-1}$ in 2005 to $90-128 \mathrm{Tg} \mathrm{N} \mathrm{yr}^{-1}$ by year 2100 with projected increases in $\mathrm{CO}_{2}$ concentrations under a business-as-usual emission scenario (scenario IS92a).

Hutchins et al. (2009) estimated that $\mathrm{N}_{2}$ fixation by Trichodesmium alone will rise from present-day levels of $60 \mathrm{Tg} \mathrm{N} \mathrm{yr}^{-1}$ (Mahaffey et al., 2005) to $80-100 \mathrm{Tg} \mathrm{N} \mathrm{yr}^{-1}$ by 2100 , based on the response of a Trichodesmium isolate to increasing $\mathrm{CO}_{2}$ levels. Hutchins et al. (2007) found that $\mathrm{N}_{2}$-fixation rates for Trichodesmium levelled off at 1250 and $1500 \mathrm{ppm}$, suggesting that $\mathrm{N}_{2}$-fixation rates may stop increasing with increasing $\mathrm{CO}_{2}$ levels by the year 2100 .

Recent evidence indicates that unicellular cyanobacteria may fix at least as much $\mathrm{N}$ as Trichodesmium (Montoya et al., 2004). A laboratory study using the unicellular cyanobacterium Crocosphaera watsonii found that elevating $\mathrm{CO}_{2}$ lev- els from 380 to $750 \mathrm{ppm}$ increased $\mathrm{N}_{2}$-fixation rates by $40 \%$ (Fu et al., 2008), when not limited by iron. Based on measurements of the increase in $\mathrm{N}_{2}$ fixation rates associated with $\mathrm{CO}_{2}$ increases for seven strains of Trichodesmium and Crocosphaera, Hutchins et al. (2013) predict that over the next 100 years, $\mathrm{N}_{2}$-fixation rates will increase by $4-23 \%$ for these seven strains. More evidence is needed to determine if other diazotrophs will be similarly affected by rising $\mathrm{CO}_{2}$ concentrations. Barcelos e Ramos et al. (2007) predicted that $\mathrm{N}_{2}$ fixation rates would increase by $50 \%$ by year 2100 with projected increases in $\mathrm{CO}_{2}$ concentration.

Anthropogenic $\mathrm{N}$ fertilization of the ocean leads to an increase in marine uptake of $\mathrm{CO}_{2}$; however, this may lead to an increase in $\mathrm{N}_{2} \mathrm{O}$ emissions. Duce et al. (2008) applied Redfield stoichiometry to estimates of anthropogenic $\mathrm{N}_{\mathrm{r}}$ deposition of $54 \mathrm{Tg} \mathrm{N} \mathrm{yr}^{-1}$ and anthropogenic $\mathrm{CO}_{2}$ uptake by the ocean of $\sim 2.2 \pm 0.5 \mathrm{PgC} \mathrm{yr}^{-1}$, and calculated that the ocean may take up an additional $10 \%$ of atmospheric anthropogenic $\mathrm{CO}_{2}$ as a result of atmospheric deposition of $\mathrm{N}_{\mathrm{r}}$. However, up to two-thirds of the decrease in radiative forcing generated by this drawdown of $\mathrm{CO}_{2}$ may be offset by an increase in radiative forcing associated with an increase in the emissions of $\mathrm{N}_{2} \mathrm{O}$ (Duce et al., 2008). A decrease in $\mathrm{pH}$ due to ocean acidification from rising $\mathrm{CO}_{2}$ levels may lead to a decrease in the bioavailability of iron (Shi et al., 2010), which may in turn lead to a decrease in $\mathrm{N}_{2}$ fixation for diazotrophs in areas where iron is limiting.

Table 2 provides a summary of the factors influencing marine $\mathrm{N}$ fixation and the expected effects on marine $\mathrm{BNF}$ in the 21 st century.

\subsubsection{Present-day and pre-industrial estimates}

Estimates of global ocean $\mathrm{N}_{2}$ fixation (shown in Fig. 2) range from 75 to $200 \mathrm{Tg} \mathrm{N} \mathrm{yr}^{-1}$ (Galloway et al., 2004; Carpenter and Capone, 2008; Moore et al., 2006; Deutsch et al., 2007; Eugster and Gruber, 2012; Luo et al., 2012), with recent estimates at around 130-140 $\mathrm{Tg} \mathrm{N} \mathrm{yr}^{-1}$ (Deutsch et al., 2007; Eugster and Gruber, 2012; Luo et al., 2012). Deutsch et al. (2007) estimated global ocean $\mathrm{N}$ fixation to be $140 \mathrm{Tg} \mathrm{N} \mathrm{yr}^{-1}$, using observed nutrient concentrations and an ocean circulation model. Eugster and Gruber (2012) used two methods to estimate the preindustrial global nitrogen fixation rate in the oceans to be $131 \mathrm{Tg} \mathrm{Nyr}^{-1}(94,175)$ and $134 \mathrm{Tg} \mathrm{N} \mathrm{yr}^{-1}$ (117, 150), by combining geochemical observations with a two-dimensional box model. Deutsch et al. (2007) and Eugster and Gruber (2012) found that the rates of $\mathrm{N}_{2}$ fixation were higher in the Pacific Ocean than the Atlantic. Luo et al. (2012) compiled a global database of diazotroph abundances and $\mathrm{N}_{2}$-fixation rates and estimated the global pelagic (open ocean) $\mathrm{N}_{2}$-fixation rate to be $140 \pm 9.2 \mathrm{Tg} \mathrm{N} \mathrm{yr}^{-1}$ (arithmetic mean \pm 1 standard error). One possible limitation of this approach is that $99 \%$ of the data were collected within the range of $40^{\circ} \mathrm{S}$ to $55^{\circ} \mathrm{N}$, and if substantial $\mathrm{N}_{2}$ fixation is found to occur outside of this range, 
Table 2. Summary of future impacts of factors affecting marine nitrogen fixation.

\begin{tabular}{ll}
\hline Factor & Effect on $\mathrm{N}_{2}$ fixation \\
\hline $\mathrm{CO}_{2}$ increase (and decrease in $\mathrm{pH}$ ) & +35 to $121 \%$ by 2100 \\
Temperature increase leading to expansion of diazotroph habitat & $+27 \%$ \\
Temperature increase leading to faster enzyme activity & + \\
Stratification leading to shortage of nutrients in surface waters & + \\
Dust containing iron & + or - \\
Increase in oxygen minimum zones & + \\
Increase in nitrogen export from rivers & - \\
Increase in deposition of reactive nitrogen & - \\
Improved measurement methods & + \\
Phosphorus & Limiting nutrient \\
\hline
\end{tabular}

it may be an underestimate. Y.-W. Luo et al. (2014) applied a multiple linear regression model to the same database of field observations and found an estimate of $\mathrm{N}_{2}$ fixation of 74 (51-110) $\mathrm{Tg} \mathrm{N} \mathrm{yr}^{-1}$ for the open ocean.

Luo et al. (2012) note that the most common method for field measurements of $\mathrm{N}_{2}$ fixation has recently been found to underestimate the rates for Trichodesmium by $62 \%$ (Großkopf et al., 2012). Extrapolating from the differences found between the ${ }^{15} \mathrm{~N}_{2}$ tracer bubble-addition and dissolution methods, Großkopf et al. (2012) estimate that the global marine $\mathrm{N}$-fixation rate measured using the new method would be $177 \pm 8 \mathrm{Tg} \mathrm{N} \mathrm{yr}^{-1}$.

Although recent midpoint estimates appear to have coalesced at around $130-140 \mathrm{Tg} \mathrm{N} \mathrm{yr}^{-1}$, there is still a great deal of uncertainty due to the large variance in measurements (Luo et al., 2012) and recent measurements of nitrogen fixation rates in areas not previously thought to have high levels of diazotrophy.

\subsubsection{Effects of global change on marine biological nitrogen fixation}

The most important effects will likely be due to temperature and increasing $\mathrm{CO}_{2}$ concentrations. Marine $\mathrm{BNF}$ will increase from present-day estimates of 120 (100200) $\mathrm{Tg} \mathrm{N} \mathrm{yr}^{-1}$ to 166 (120-240) $\mathrm{Tg} \mathrm{N} \mathrm{yr}^{-1}$ due to temperature effects alone. Present-day BNF estimates were scaled up using the $Q_{10}$ of 1.64 for Trichodesmium $\left(15-20^{\circ} \mathrm{C}\right)$ (Staal et al., 2003).

In addition to the factors discussed above, estimates of $\mathrm{N}$ fixation may increase in the future even if the actual rate remained constant. This is because the most common method for taking field measurements of marine $\mathrm{N}$ fixation has recently been found to underestimate the rate, so future estimates of $\mathrm{N}$ fixation may increase as the methods become more accurate (Großkopf et al., 2012). In addition, recent evidence suggests that regions such as coastal, aphotic and arctic regions may exhibit more $\mathrm{N}_{2}$ fixation than previously thought.
Taken together, the factors discussed above suggest that marine $\mathrm{N}$ fixation will increase in the future, which may lead to an increase in ocean drawdown of $\mathrm{CO}_{2}$. Several feedbacks may offset this increase. Increasing rates of $\mathrm{N}_{2}$ fixation may drive areas to $\mathrm{P}$ and iron limitation, thereby limiting ultimate $\mathrm{N}_{2}$-fixation rates.

\subsection{Global changes in natural BNF 2010 to 2100}

It appears likely that global BNF will increase during this century in marine and terrestrial ecosystems. The total terrestrial natural $\mathrm{N}$ fixation by the end of this century suggested from these arguments is $170 \mathrm{Tg} \mathrm{N}$ annually, approximately $40 \%$ larger than the value at the beginning of the 20th century. Marine BNF is projected to increase from 120 to $166 \mathrm{Tg} \mathrm{N} \mathrm{yr}^{-1}$ by 2100 , an increase of $38 \%$ on the 2010 value.

\section{Anthropogenic fixation of nitrogen in the 21st century}

Human demand for fixed $\mathrm{N}$ through the 21 st century will be driven by requirements for food and industrial use. There is also unintended nitrogen fixation resulting from combustionrelated $\mathrm{NO}_{x}$ emissions. Set against these drivers for increased $\mathrm{N}_{\mathrm{r}}$ fixation, control measures to mitigate emissions will regulate the net anthropogenic contribution to global nitrogen fixation. A range of authors have considered the available scenarios and possible development trajectories including most recently Winiwarter et al. (2013) and Bouwman et al. (2013). The scenarios and time scales used by these authors differ, with Bouwman et al. (2013) projecting trends to 2050, rather than the end of the century. However, given the uncertainty in projections of this kind, they provide a useful guide for the likely trends. The projections from Winiwarter et al. (2013) are based on story lines and methodologies similar to those of the RCPs (representative concentration pathways) as used in the 2014 IPCC assessment of climate change through the 21 st century. However, while based on the RCP scenarios, only the $\mathrm{N}_{\mathrm{r}}$ from combustion is taken 


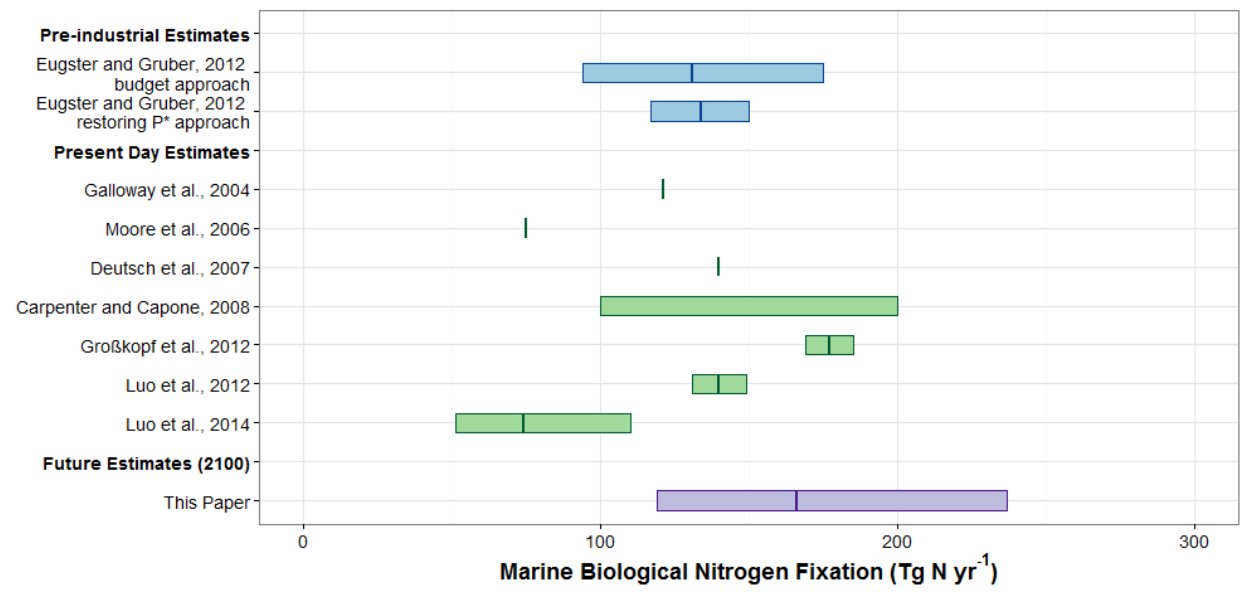

Figure 2. Summary of pre-industrial (blue), present (green), and future (purple) estimates of marine biological nitrogen fixation (BNF). Estimate from Carpenter and Capone (2008) represents their summary of the range presented in the literature, and includes no midpoint. Luo et al. (2012) values are arithmetic mean \pm standard error, so range limits may not be directly comparable to other estimate range limits. Estimates for fixation by Trichodesmium alone by Barcelos e Ramos et al. (2007) (60-85 $\mathrm{Tg} \mathrm{N} \mathrm{yr}^{-1}$ in $2005,90-128 \mathrm{Tg} \mathrm{N}^{-1}$ by year $^{-1}$ 2100) and Hutchins et al. (2009) (80-100 $\mathrm{Tg} \mathrm{N} \mathrm{yr}^{-1}$ by 2100) are included in text but not presented in figure because the estimates in the figure are for total marine BNF.

directly from the IPCC methods as $\mathrm{N}_{\mathrm{r}}$ formation was not a focus of the scenario developments for the IPCC. Together with mineral fertilizer and industrial use of $\mathrm{N}_{\mathrm{r}}$, fixation is projected in the range 140 to $235 \mathrm{Tg} \mathrm{N} \mathrm{yr}^{-1}$ by 2100 , depending on the RCP chosen, and compares with their estimate of $170 \mathrm{Tg} \mathrm{N} \mathrm{yr}^{-1}$ in 2000 . The year 2000 value is smaller than the estimate of $210 \mathrm{Tg} \mathrm{Nyr}^{-1}$ by Fowler at al. (2013) but within the uncertainties shown in each synthesis. The projections from Winiwarter et al. (2013) imply modest overall change in $\mathrm{N}_{\mathrm{r}}$ production by human activity through the $21 \mathrm{st}$ century as a consequence of gradual increases in efficiency compensating for increases in demand for fertilizer and industrial $\mathrm{N}_{\mathrm{r}}$ applications, combined with reductions in nitrogen oxide $\left(\mathrm{NO}_{x}\right)$ emissions from combustion resulting from expected emission controls. Indeed, there have been important reductions in emissions of combustion $\mathrm{N}_{\mathrm{r}}$, as $\mathrm{NO}_{x}$ to the atmosphere throughout Europe, North America and other highly developed economies. Typically these have reduced $\mathrm{NO}_{x}$ emissions by about $50 \%$ over the last 30 years in these regions. Similar controls are likely for combustion emissions in the rapidly developing economies of Asia in the decades ahead. However, for reduced $\mathrm{N}$, the global trend has been a monotonic increase in $\mathrm{N}_{\mathrm{r}}$ fixation for most countries in the world outside Europe, and the social trends in rapidly developing economies towards increased meat consumption seem likely to continue the trend. Given these historical trends and the unwillingness of governments throughout the world to regulate the supply of reduced $\mathrm{N}_{\mathrm{r}}$ for agriculture and industry, the assumption that $\mathrm{N}_{\mathrm{r}}$ production will remain constant through the 21 st century seems implausible.

A substantial increase in nitrogen use efficiency (NUE) seems likely, as has been achieved in European agriculture over the last 30 years, but this is unlikely to prevent a continued increase in global agricultural nitrogen use. Given that human $\mathrm{N}_{\mathrm{r}}$ production doubled between 1980 and 2010, a period in which global population increased by 2.5 billion, and most projections show a similar population increase during the 21 st century, the demand for food and other nitrogen-consuming activities (transport, heating and consumer goods) will most likely lead to a substantial increase in industrial $\mathrm{N}$ fixation. Assuming NUE increases, it is possible that anthropogenic $\mathrm{N}$ fixation grows only by $30 \%$ between 2010 and 2100. This simplistic assumption would lead to $2100 \mathrm{~N}_{\mathrm{r}}$ production through the Haber-Bosch process of $160 \mathrm{Tg} \mathrm{N} \mathrm{yr}^{-1}$ and total annual anthropogenic production $\mathrm{N}_{\mathrm{r}}$ of $259 \mathrm{Tg} \mathrm{N} \mathrm{yr}^{-1}$.

The global changes in fixation discussed above are summarized in Fig. 3, which show large increases in the total $\mathrm{N}$ fixed from $473 \mathrm{Tg} \mathrm{N} \mathrm{yr}^{-1}$ in 2010 to $602 \mathrm{Tg} \mathrm{N} \mathrm{yr}^{-1}$ in 2100 accompanied by substantial increases in the uncertainties of the component fluxes.

The $\mathrm{N}_{\mathrm{r}}$ fixed by BNF and human activity is then used by and transformed within ecosystems and products of the chemical and biological processing cascade through terrestrial and marine ecosystems and the atmosphere. It is important now to consider the effect of changes in the environment this century on the fate of the $\mathrm{N}_{\mathrm{r}}$.

\section{Effects of environmental changes on the fate of $N_{r}$ in terrestrial and marine ecosystems}

The total fixation of $\mathrm{N}$ through natural (BNF), combustion and Haber-Bosch processes is projected to increase during the remainder of the 21 st century, possibly to approximately 


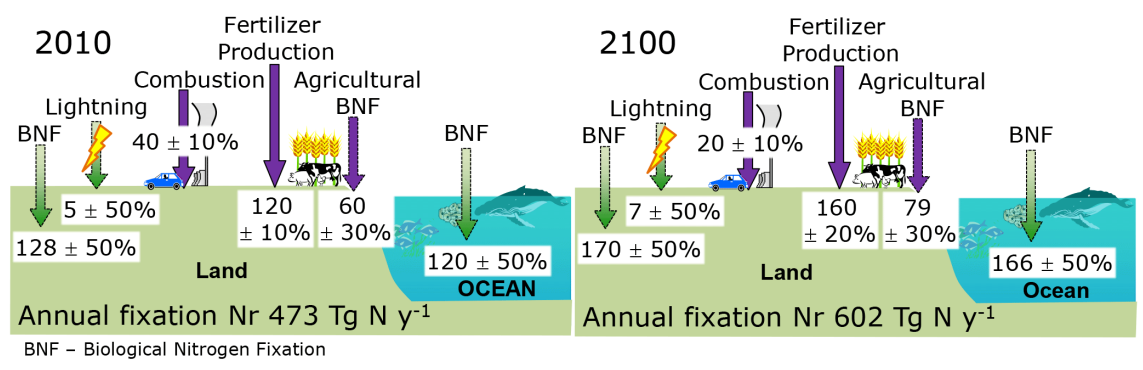

Figure 3. Global biological nitrogen fixation (BNF) in natural ecosystems and by lightning (green arrows) and nitrogen fixation as a consequence of human activities (purple arrows) including agriculture, combustion and industrial processes for 2010 and 2100.

$600 \mathrm{Tg} \mathrm{N}$, an increase of $50 \%$ over values at the beginning of the century (Fig. 3). The subsequent fate of the $\mathrm{N}_{\mathrm{r}}$ in terrestrial and marine ecosystems and the responses of the different pools of $\mathrm{N}_{\mathrm{r}}$ to changes in climate, and especially temperature, are now considered for terrestrial and marine ecosystems.

The fixed $\mathrm{N}$, whether by natural processes in soils and the oceans or by human activities, is predominantly in the reduced form as ammonia $\left(\mathrm{NH}_{3}\right)$ or ammonium $\left(\mathrm{NH}_{4}^{+}\right)$initially. Once formed, $\mathrm{N}_{\mathrm{r}}$ is readily transformed in the environment and it is important to describe the likely effects of changes in the environment on the fate of $\mathrm{N}_{\mathrm{r}}$ and quantify, where possible, the probable impacts due to climate and landuse change - in short, what are the components of the $\mathrm{N}$ cycle that are most responsive to expected changes in climate and land use?

\subsection{Terrestrial ecosystems: emissions of $\mathrm{NH}_{3}$ from terrestrial ecosystems through the 21st century}

The global total emissions of $\mathrm{NH}_{3}$ to the atmosphere at the beginning of the 21st century have been estimated by Sutton et al. (2013b) to be $59.3 \mathrm{Tg} \mathrm{Nyr}^{-1}$, of which $33 \mathrm{Tg} \mathrm{Nyr}^{-1}$ is from livestock and crops. The $\mathrm{N}_{\mathrm{r}}$ fixed industrially through $\mathrm{NH}_{3}$ manufacture, mainly for fertilizers, is currently $120 \mathrm{Tg} \mathrm{N} \mathrm{yr}^{-1}$; thus the emissions to the atmosphere from livestock and crops represent roughly a quarter of the annual fertilizer production, effectively fertilizing the atmosphere. This, substantial quantity is the unintentional leakage of the $\mathrm{N}_{\mathrm{r}}$ from farming systems due to the volatility of $\mathrm{NH}_{3}$. Also presented in this analysis of global emissions of $\mathrm{NH}_{3}$ are values for emissions from all other major sources. Given the spatial and temporal variability in emission rates and the sensitivity to climate, and especially temperature, the range of different emission estimates is small among the seven different estimates ( 35 to $65 \mathrm{Tg} \mathrm{yr}^{-1}$ ) summarized, which reflects the fact that these estimates are not fully independent. It is suggested by Sutton et al. (2013b) that overall uncertainty is around $\pm 30 \%$, pointing to a range of emissions for 2008 of 46 to $85 \mathrm{Tg} \mathrm{N} \mathrm{yr}^{-1}$.

The forces which have governed overall industrial production of fixed $\mathrm{N}$ have largely been economic, responding to the demand for food and the response functions between crop productivity and fertilizer use (Jensen et al., 2011) in which the economic benefits of increased yields have driven global $\mathrm{N}$ fertilizer use demand. At the same time, an increase in global meat consumption per capita (Erisman et al., 2008) has magnified fertilizer requirements and $\mathrm{NH}_{3}$ emissions (Westhoek et al., 2014). This includes both the $\mathrm{NH}_{3}$ emissions from fertilizer in growing animal feeds and the ammonia emissions from livestock manures, in animal houses, manure storage, land application and from grazing animals, where the use of housed livestock substantially increases emissions compared with pasture-only systems.

Global projections for future $\mathrm{N}_{\mathrm{r}}$ use have not generally included possible control measures to reduce emissions of $\mathrm{NH}_{3}$ to the atmosphere, which would increase the NUE. There are exceptions, in the case of the Netherlands and in Denmark, where policies to reduce the leakage of $\mathrm{N}_{\mathrm{r}}$ to the environment led to substantial reductions in atmospheric emissions (EMEP, 2014). Although first NUE estimates have now been provided for each country in the world (Sutton et al., 2013a), it is a matter for ongoing and future analysis to show how these have evolved over time and to demonstrate the quantitative relationships between reduction between $\mathrm{N}$ emissions, including $\mathrm{NH}_{3}$, and improvement of NUE. In the global projections of $\mathrm{N}_{\mathrm{r}}$ use through the 21st century provided by both Erisman et al. (2008, using the SRES approach) and Winiwarter et al. (2013, using the RCP approach), scenarios included the potential to improve crop NUE, while Sutton et al. (2013a), examined the $\mathrm{N}$ savings possible also as a result of improving NUE across the full agri-food chain.

Global demand for food is likely to increase by $40 \%$ by 2050 due to population growth and a changing diet (Godfray et al., 2010), especially in the rapidly developing regions. The largest uncertainties in estimating future emissions of $\mathrm{NH}_{3}$ to the atmosphere are the consumption drivers (food amount, food choice), the amounts of fertilizer and manure $\mathrm{N}$ applied and the effect of climate on the fraction emitted (van Vuuren et al., 2011a; Sutton et al., 2013b). Excluding the climatic interaction (which is addressed below), emissions resulting from demand for food and industrial uses have been estimated by van Vuuren et al. (2011a) to increase 
from $60 \mathrm{Tg} \mathrm{Nyr}^{-1}$ in 2000 to between 70 and $80 \mathrm{Tg} \mathrm{N} \mathrm{yr}^{-1}$ by 2100 .

\subsubsection{Effects of changes in climate on terrestrial emissions of $\mathrm{NH}_{3}$}

The processes of exchange of $\mathrm{NH}_{3}$ between terrestrial ecosystems and the atmosphere have been subject to detailed field studies and intercomparisons of methods (Sutton et al., 1995, 1998, 2009; Flechard et al., 1999, 2013) and are discussed further in this review. The most recent estimates of the influence of climate change on emissions of $\mathrm{NH}_{3}$ are by Sutton et al. (2013b).

The surface-atmosphere exchange of $\mathrm{NH}_{3}$ is generally described numerically using a resistance analogy in which the vertical flux $\left(F_{t}\right)$ is given by the potential difference between the surface and a reference height in the atmosphere divided by the sum of resistances in the pathway from the source to the reference height and comprising $R_{\mathrm{a}}(z)$ and $R_{\mathrm{b}}$, the turbulent atmospheric and quasi-laminar boundary layer resistances respectively.

$F_{t}=\left[\chi\left(z_{o^{\prime}}\right)-\chi(z)\right] /\left[R_{\mathrm{a}}(z)+R_{\mathrm{b}}\right]$

In most ecosystems, the concentration at the surface $\left(\chi z_{o^{\prime}}\right)$ is non-zero, due to presence of $\mathrm{NH}_{4}^{+}$in the apoplast of vegetation. In these conditions the value of $\chi z_{o^{\prime}}$ is proportional to a ratio $\Gamma=\left[\mathrm{NH}_{4}^{+}\right] /\left[\mathrm{H}^{+}\right]$of the canopy / ground surface, where according to the thermodynamics

$\left.\chi=161500 / T \exp ^{(-10380 / T}\right)\left[\mathrm{NH}_{4}^{+}\right] /\left[\mathrm{H}^{+}\right]$,

where temperatures $(T)$ are in kelvin, and the scheme is represented schematically in Fig. 4.

The bi-directional exchange between surface and atmosphere of $\mathrm{NH}_{3}$ modifies the spatial patterns of $\mathrm{NH}_{3}$ fluxes in the landscape, with reduced emission or even deposition downwind of large sources (Fowler et al., 1998). Quantifying changes in $\mathrm{NH}_{3}$ emission this century requires knowledge of apoplast and leaf litter $\mathrm{NH}_{4}^{+}$and $\mathrm{pH}$, scaled through the coming decades over global vegetation. The data required to calculate net exchange fluxes in this way are not available. However, Sutton et al. (2013b) argue that by examining model ecosystems and their exchange of $\mathrm{NH}_{3}$ a surrogate for the likely change may be seen in empirical data. When it comes to global upscaling of $\mathrm{NH}_{3}$ emissions, this also needs to bear in mind that the wide range of different terrestrial $\mathrm{NH}_{3}$ sources are likely to have differing temperature responses, due to the role of different interacting factors.

To illustrate these effects, a model ecosystem was used for which both a global modelling framework and field measurements are uniquely available, namely $\mathrm{NH}_{3}$ emission from seabird colonies. In addition to the availability of measurements and modelling, they are also globally important sources of $\mathrm{NH}_{3}$ and are distributed geographically across a broad range of climates, with minimal human intervention so

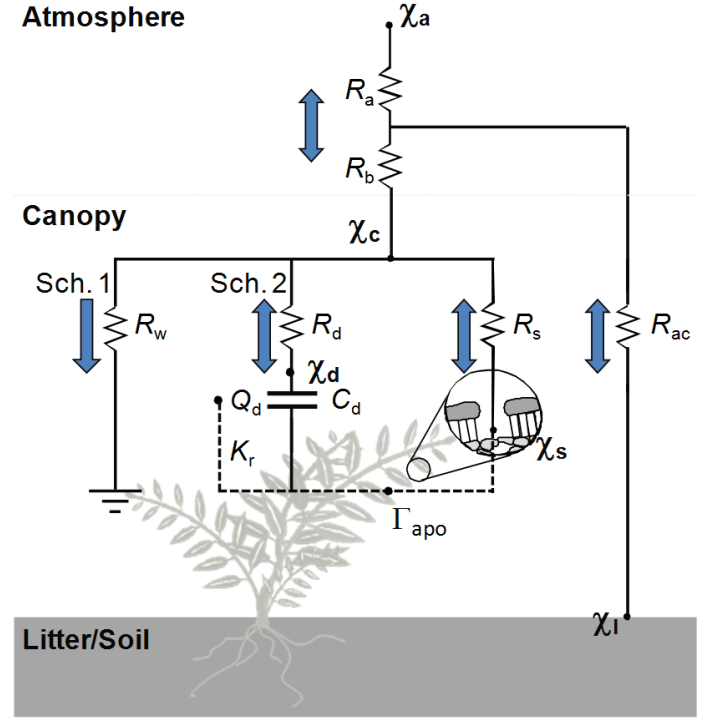

Figure 4. A resistance analogue of $\mathrm{NH}_{3}$ exchange including cuticular, stomatal, and pathways to soil (Sutton et al., 2013b). Two methods for cuticular exchange schemes are shown: (1) steady-state uptake according to a varying cuticular resistance $\left(R_{\mathrm{W}}\right)$; $(2) \mathrm{dy}$ namic exchange with a reservoir of $\mathrm{NH}_{4}^{+}$using a varying capacitance $\left(C_{\mathrm{d}}\right)$ and charge $\left(Q_{\mathrm{d}}\right)$. Within-canopy transfer $\left(R_{\mathrm{ac}}\right)$, cuticular adsorption-desorption $\left(R_{\mathrm{d}}\right)$ and stomatal exchange $\left(R_{\mathrm{S}}\right)$. Also shown are the air concentration $\left(\chi_{\mathrm{a}}\right)$, cuticular concentration $\left(\chi_{\mathrm{d}}\right)$, stomatal compensation point $\left(\chi_{\mathrm{s}}\right)$, litter-soil surface concentration $\left(\chi_{1}\right)$ and the canopy compensation point $\left(\chi_{\mathrm{c}}\right)$.

that the effects of climate differences can be assessed without confounding management interactions (Blackall et al., 2007; Riddick et al., 2012; Sutton et al., 2013b). This approach demonstrated a strong climate dependence in the ammonia emissions, with the modelling approach (incorporating Eq. 2), agreeing closely with the measured data sets.

Combining all sources of $\mathrm{NH}_{3}$ emission globally, studies provided the data to model likely responses of terrestrial $\mathrm{NH}_{3}$ emissions to a $5^{\circ} \mathrm{C}$ increase in global temperature and showed that emissions in 2008 of $65 \mathrm{Tg}-\mathrm{NH}_{3}-\mathrm{N}(45-$ 85 ) increased to $93(64-125) \mathrm{Tg}-\mathrm{NH}_{3}-\mathrm{N}$ in 2100 (Sutton et al., 2013b), based on anthropogenic activity levels for 2008 . This may be compared with an estimated increase in $\mathrm{NH}_{3}$ emissions based on increased anthropogenic activities (excluding the climatic response), and of no change for natural sources, of $42 \%$ (33-52\%) increase by 2100 . Combining the increases in anthropogenic activity expected up to 2100 according to the RCP8.5 (Lamarque et al., 2011), with the estimated effect of climate warming on emissions, gives an overall estimate of $\mathrm{NH}_{3}$ emissions for 2100 of 135 (89179) ${\mathrm{Tg} \mathrm{N} \mathrm{r}^{-1}}^{-}$. As Sutton et al. (2013b, Supplement) point out, this value is nearly a factor of 3 higher than that included in the currently mapped EDGAR database, which is a consequence of including (a) additional sources (including oceans, see further below), (b) the effect of the climate change feed- 
back and (c) the anticipated increase in anthropogenic activities.

\subsection{Ammonia exchange over the oceans in the 21st century}

In marine ecosystems $\mathrm{NH}_{3} / \mathrm{NH}_{4}^{+}$is produced by phytoplankton and other organisms. Although the aqueous-phase partitioning between $\mathrm{NH}_{3}$ and its protonated form $\mathrm{NH}_{4}^{+}$is dominated by $\mathrm{NH}_{4}^{+}$, the majority of emissions are in the form of $\mathrm{NH}_{3}$. Ammonium is quickly assimilated by phytoplankton, so $\mathrm{NH}_{3}$ and $\mathrm{NH}_{4}^{+}$are usually present in low concentrations in the surface ocean.

\subsubsection{Factors affecting the flux of ammonia between the atmosphere and the ocean}

The exchange of ammonia between the ocean and the atmosphere depends on several factors: the concentrations of ammonia in the surface layer of the ocean and in the boundary layer of the atmosphere, temperature, and wind speed (Johnson et al., 2008). The flux across the atmosphere-ocean interface can be described by (Liss and Slater, 1974) the following:

$F=k_{\mathrm{g}}\left\{\left(\mathrm{NH}_{3(\mathrm{~g})}\right)-K_{\mathrm{H}}\left[\mathrm{NH}_{3(\mathrm{sw})}\right]\right\}$,

where $F$ is the flux between the atmosphere and the ocean $\left(\mathrm{mol} \mathrm{m}{ }^{-2} \mathrm{~s}^{-1}\right), k_{\mathrm{g}}$ is the gas-phase transfer velocity $\left(\mathrm{m} \mathrm{s}^{-1}\right)$, the $\mathrm{NH}_{3}$ concentrations are given in $\mathrm{mol} \mathrm{m}^{-3}$, and $K_{\mathrm{H}}$ is the dimensionless Henry's law coefficient for ammonia, and $\mathrm{NH}_{3(\mathrm{sw})}$ refers to surface water $\mathrm{NH}_{3}$ concentration.

The Henry's law constant for ammonia can be calculated as follows (McKee, 2001):

$K_{\mathrm{H}}=\left(17.93(T / 273.15) e^{(4092 / T)-9.70}\right)^{-1}$,

where $T$ is temperature in kelvin.

The concentration of $\mathrm{NH}_{3}$ present in seawater depends on the partitioning between $\mathrm{NH}_{3}$ and $\mathrm{NH}_{4}^{+}$, which is affected by $\mathrm{pH}$, salinity, and temperature. This dissociation can be described by the logarithmic acid dissociation constant, $\mathrm{pKa}$ (Bell et al., 2007):

$\mathrm{pKa}=10.0423-(0.0315536 T)+(0.003071 S)$,

where $T$ is the temperature in ${ }^{\circ} \mathrm{C}$, and $S$ is salinity in $\mathrm{g} \mathrm{kg}^{-1}$. Chemical reactions and transport of $\mathrm{NH}_{3}$ into the atmosphere (from terrestrial emissions) and the ocean (from biological activity, deposition and river export) also affect the levels of $\mathrm{NH}_{3}$ present.

\subsubsection{Flux estimates}

The present-day direction of $\mathrm{NH}_{3}$ flux is believed to be from the atmosphere to the oceans at high latitudes, where the oceans are colder, allowing more gases such as $\mathrm{NH}_{3}$ to be dissolved. In contrast, the oceans are believed to be a source of $\mathrm{NH}_{3}$ emissions at lower latitudes, where the oceans are warmer, promoting a greater partitioning to the gas phase (Eq. 4 and Johnson et al., 2008). When considering the global oceans together, the net flux is believed to be a small emission from the oceans to the atmosphere (Bouwman et al., 1997; Dentener and Crutzen, 1994; Galloway et al., 2004).

Ocean-atmosphere $\mathrm{NH}_{3}$ fluxes vary across regions and seasons, and observations are limited. As a result, there are only a few quantitative estimates of global flux, all of which are highly uncertain. Dentener and Crutzen (1994) estimated the flux to be $7.0 \mathrm{Tg} \mathrm{N} \mathrm{yr}^{-1}$ from the oceans to the atmosphere. They did this by taking a distribution of dimethyl sulfide (DMS) emissions modelled by Bates et al. (1987), and assuming equal molar emissions of $\mathrm{NH}_{3}$ and DMS. Although both DMS and $\mathrm{NH}_{3}$ are produced by phytoplankton, assuming an equal molar relationship is acknowledged by Dentener and Crutzen (1994) to be speculative. The relationship between $\mathrm{NH}_{3}$ and DMS may have been tightly coupled under pre-industrial conditions, but this is unlikely to be true under the present strong anthropogenic influences on the $\mathrm{N}$ cycle (Johnson and Bell, 2008), especially in coastal waters.

An independent estimate of global ocean $\mathrm{NH}_{3}$ emissions was provided by Bouwman et al. (1997), who applied an ocean carbon cycle model to calculate an $\mathrm{NH}_{3}$ flux of 8.2 $\mathrm{Tg} \mathrm{N} \mathrm{yr}^{-1}$ for 1990 . However, this did not account for non-zero atmospheric $\mathrm{NH}_{3}$ concentrations, and Bouwman et al. (1997) acknowledged that doing so might reduce the net sea-atmosphere emission flux by a factor of 2 . For comparison, Galloway et al. (2004) estimated preindustrial, present, and future marine $\mathrm{NH}_{3}$ emissions using a compensation point approach to be $5.6 \mathrm{Tg} \mathrm{N} \mathrm{yr}^{-1}$. However, it is unlikely that the flux would remain constant over these time periods, given the human perturbations to the $\mathrm{N}$ cycle.

Steadman et al. (2015) have improved these estimates by implementing the bi-directional flux calculation method described by Johnson et al. (2008), following Eqs. (3)-(5), accounting for both regional and temporal patterns in ocean and atmospheric concentrations of $\mathrm{NH}_{3}$ and temperature. The flux is calculated by dividing the ocean surface into 5 degree grid squares, and determining the gas transfer velocity and the Henry's law constant for $\mathrm{NH}_{3}$ within each grid square, using temperature, $\mathrm{pH}$, and wind speed. The resulting estimated $\mathrm{NH}_{3}$ flux for 2005 is $5.7 \mathrm{Tg} \mathrm{N} \mathrm{yr}^{-1}$ from the ocean to the atmosphere. Atmospheric concentrations of $\mathrm{NH}_{3}$ were obtained from STOCHEM (Lamarque et al., 2013; Derwent et al., 2003) model output. Surface ocean $\mathrm{NH}_{3}$ and $\mathrm{NH}_{4}^{+}$concentrations were obtained from the British Oceanographic Data Centre.

These recent analyses suggest that the global $\mathrm{NH}_{3}$ emission estimate of $8.2 \mathrm{Tg} \mathrm{Nyr}^{-1}$ of Bouwman et al. (1997), which was incorporated into the global emissions estimates of Sutton et al. (2013b), summarized above, may be overestimated. If so, the estimates of Sutton et al. (2013b) should be reduced by around $2.5 \mathrm{Tg} \mathrm{Nyr}^{-1}$ for 2008 , giving total 
emissions of $63(44-82) \mathrm{Tg} \mathrm{N} \mathrm{yr}^{-1}$, again based on $\sim 30 \%$ uncertainty.

\subsubsection{Future impacts}

The future ocean-atmosphere flux of $\mathrm{NH}_{3}$ will be affected by increasing temperatures, increasing terrestrial $\mathrm{NH}_{3}$ emissions, and ocean acidification from elevated $\mathrm{CO}_{2}$ levels, which lowers the $\mathrm{pH}$ of the water. The mechanism of both of these effects is an alteration of the partitioning of ammonia and ammonium in the ocean, as illustrated by Eq. (5). The lower $\mathrm{pH}$ results in a greater relative concentration of ammonium. The lower concentration of $\mathrm{NH}_{3}$ will therefore result in lower emissions. Climate change and ocean acidification will also have indirect effects on ocean ecosystems, leading to changes in plankton populations and species composition.

The decreased marine emissions of $\mathrm{NH}_{3}$ in the future, combined with increasing $\mathrm{N}$ deposition and export from rivers, suggest that the future oceans may accumulate more reactive $\mathrm{N}$, leading to eutrophication and OMZs. Some of the additional $\mathrm{N}_{\mathrm{r}}$ may result in an increase in denitrification and associated $\mathrm{N}_{2} \mathrm{O}$ emissions.

The expected temperature and $\mathrm{pH}$ changes in the ocean associated with climate change and ocean acidification will likely have a large effect on the ammonia flux. Based on the estimates of Bouwman et al. (1997), Eq. (2) and a $5{ }^{\circ} \mathrm{C}$ warming scenario, Sutton et al. (2013b, supplementary material) estimated that ocean $\mathrm{NH}_{3}$ emissions would increase to $15 \mathrm{Tg} \mathrm{N} \mathrm{yr}^{-1}$. However, as noted above, the baseline may have been an overestimate, while the interaction with rising $\mathrm{CO}_{2}$ levels was not included.

Preliminary model results suggest that after accounting for the increasing temperatures and terrestrial emissions associated with RCP8.5, and the expected ocean acidification (a decrease in mean surface ocean $\mathrm{pH}$ of 0.31 , from 8.14 in 2000 to 7.83 in 2100; IPCC, 2013), the estimated future $\mathrm{NH}_{3}$ flux for 2100 is $1.7 \mathrm{Tg} \mathrm{Nyr}^{-1}$. If temperature increases and increasing terrestrial ammonia emissions are accounted for, but ocean acidification neglected (the effect of $\mathrm{pH}$ is excluded), the estimated emission for 2100 would be $9.2 \mathrm{Tg} \mathrm{N} \mathrm{yr}^{-1}$. If atmospheric $\mathrm{NH}_{3}$ concentrations and ocean $\mathrm{pH}$ were to remain at 2000 levels, but temperatures increase as expected under RCP8.5, the estimated 2100 ammonia emission is 10.9 $\mathrm{Tg} \mathrm{N} \mathrm{yr}^{-1}$. Comparison of the bars in Fig. 5 shows that in relative terms the effect of ocean acidification is the largest driver, providing more than a factor of 3 difference in the flux calculated by Eq. (3).

\subsection{Terrestrial emissions of nitric oxide and nitrous oxide}

\subsubsection{Global sources of $\mathrm{NO}$ and $\mathrm{N}_{2} \mathrm{O}$ in the atmosphere}

$\mathrm{NO}_{x}$

Sources of atmospheric $\mathrm{NO}_{x}\left(\mathrm{NO}+\mathrm{NO}_{2}\right)$ are soils, natural fires, lightning, transport from the stratosphere and combustion of fossil fuels. The sinks are in both soil through microbial uptake and the atmosphere, through reactions with $\mathrm{OH}$ (Miyazaki et al., 2012; Logan, 1983). Global $\mathrm{NO}_{x}$ emissions have increased 3-6-fold since the industrial revolution due to increased fossil fuel and biomass burning (Prather and Ehhalt, 2001). Recent new estimates of global $\mathrm{NO}_{x}$ emissions based on a combination of a top-down inventory based on satellite observations and bottom-up inventory have constrained the global emissions to $40 \mathrm{Tg} \mathrm{N} \mathrm{yr}^{-1}$ (Jaeglé et al., 2005; Martin et al., 2003). Fuel combustion (fossil and biofuel) was the largest source, contributing $58 \%$ to the total budget, followed by soils (22\%), biomass burning (14\%), lightning $(8 \%)$, stratospheric-tropospheric exchange $(0.2 \%)$ and aircraft $(0.1 \%)$ (Jaeglé et al., 2005; Martin et al., 2003). Largest soil contributions were from the African and Australian continents (39\% of total), whereas in the more industrialized US and Europe soil emissions contributed only with 12 and $18 \%$ to total emissions respectively (Fig. 6). The monthly satellite $\mathrm{NO}_{x}$ data link peak soil-derived $\mathrm{NO}_{x}$ emissions with the onset of the rainy seasons in north equatorial Africa, and $\mathrm{N}$ fertilization of agricultural land in the northern and mid-latitudes. These observations imply that the Yienger and Levy II (1995) emission factors together with the Wang et al. (1998) algorithm for canopy exchange need to be revised upward substantially (Jaeglé et al., 2005).

Hudman et al. (2012) improved the representation of soil $\mathrm{NO}_{x}$ emissions in global models by replacing the simple emission factors (Yienger and Levy II, 1995) with equations representing spatial and temporal patterns of soil moisture, temperature, pulsing, fertilizer, manure and atmospheric $\mathrm{N}$ deposition and biome. The BDSNP model (Berkeley-Dalhousie Soil $\mathrm{NO}_{x}$ Parameterization) was coupled to a global chemistry-transport model GEOS-Chem, which normally used the Yienger and Levy II (1995) (YL95) scheme for soil emissions (Wang et al., 1998), but retained the YL95 canopy reduction component. The new model calculated larger emissions for the below canopy emissions $\left(10.7 \mathrm{Tg} \mathrm{Nyr}^{-1}\right.$ ) relative to the YL95 approach $\left(7.4 \mathrm{Tg} \mathrm{Nyr}^{-1}\right)$. Total above-canopy soil $\mathrm{NO}_{x}$ emissions were calculated at $9 \mathrm{Tg} \mathrm{Nyr}^{-1}$, in good agreement with the Jaeglé et al. (2005) study. The new model was validated using satellite nitrogen dioxide $\left(\mathrm{NO}_{2}\right)$ data provided by $\mathrm{OMI}$ (Ozone Monitoring Instrument; Hudman et al., 2012). Their model was able to reproduce the monsoon-induced soil $\mathrm{NO}$ peak in north equatorial Africa and the interannual variability of soil $\mathrm{NO}_{x}$ fluxes over the Great Plains in the US. 


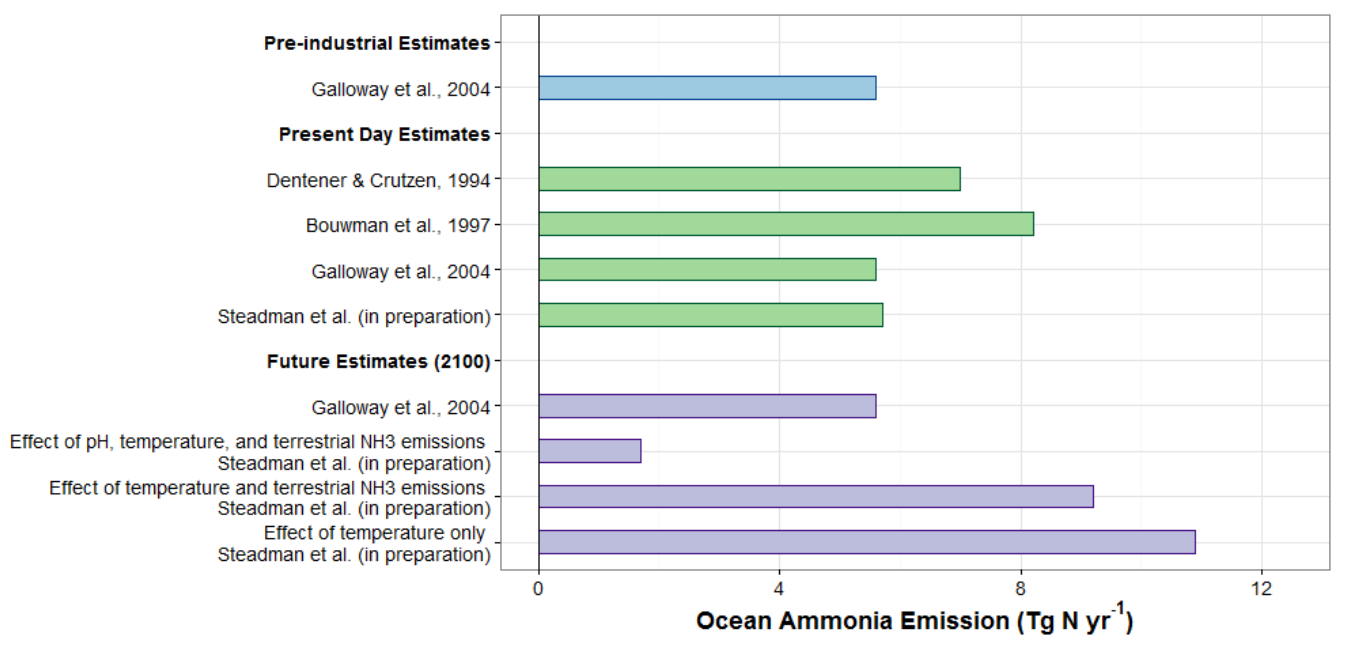

Figure 5. Summary of pre-industrial (blue), present (green), and future (purple, for 2100) estimates of marine ammonia flux from ocean to atmosphere.

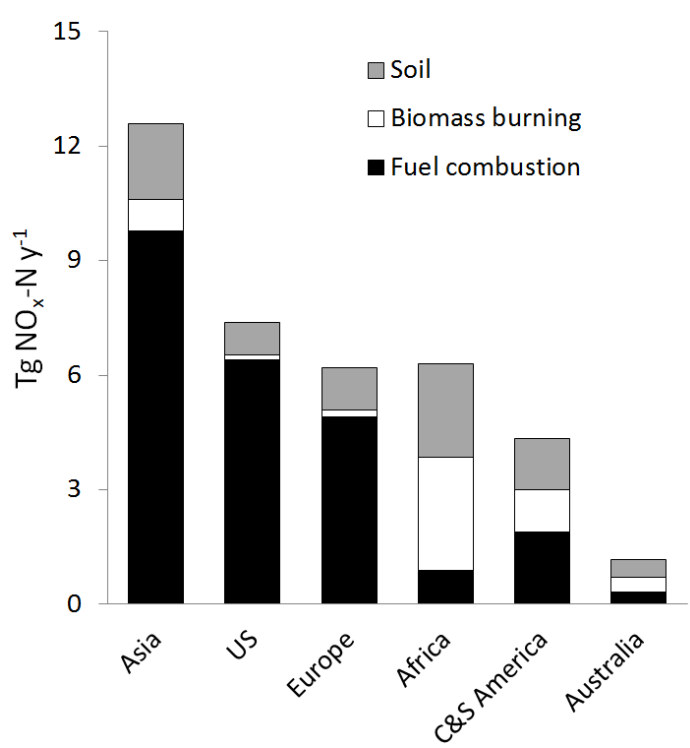

Figure 6. Spatial distribution of $\mathrm{NO}_{x}$ emissions for the year 2000 from the main sources: fossil and biofuel combustion, biomass burning and soils and main region. Data are the a posterior data (top down and bottom-up $\mathrm{NO}_{x}$ emission inventory from Jaeglé et al., 2005).

\section{$\mathbf{N}_{2} \mathbf{O}$}

Nitrous oxide, a long-lived (114 yr) greenhouse gas, contributing to $10 \%$ of the global radiative forcing (Denman et al., 2007), and in the stratosphere, is now the main cause of stratospheric $\mathrm{O}_{3}$ depletion (Ravishankara et al., 2009). Microbial denitrification and nitrification processes are responsible for $87 \%$ of the annual global $\mathrm{N}_{2} \mathrm{O}$ budget (18.8 $\mathrm{Tg} \mathrm{Nyr}^{-1}$; Syakila and Kroeze, 2011), with contributions from natural soils (35\%), agriculture (27\%) and oceans $(25 \%)$. Non-biological sources are responsible for the remaining $13 \%$ through fossil fuel combustion, biofuel and biomass burning and industrial processes. Atmospheric $\mathrm{N}_{2} \mathrm{O}$ concentrations have been rising since the industrial revolution from $270 \mathrm{ppb}$ to over $319 \mathrm{ppb}$. It has always been assumed that increased $\mathrm{N}$-fertilizer use is responsible for this rise. Recent measurements of isotopic $\mathrm{N}_{2} \mathrm{O}$ composition $\left({ }^{14 / 15} \mathrm{~N}\right)$ in the atmosphere are consistent with this assumption (Park et al., 2012), and $\mathrm{N}$-fertilized agricultural soils are responsible for almost $16 \%$ of global annual $\mathrm{N}_{2} \mathrm{O}$ emissions. All agricultural activities are responsible for two-thirds of the total anthropogenic $\mathrm{N}_{2} \mathrm{O}$ emissions (Davidson and Kanter, 2014), and more than one-third is associated with animal production.

Natural soil emissions are the largest single global source of $\mathrm{N}_{2} \mathrm{O}$, with largest emissions from the warm wet regions in the Amazon, South-East Asia and Africa. These are also the regions for which data coverage is poor relative to Europe and North America. Using an artificial neural network approach and available field observations, Zhuang et al. (2012) calculated that $30 \%$ of the total natural soil contribution was from tropical evergreen broadleaved forests followed by $17 \%$ for woody savannas. Their total estimate for global soil emissions was 3.4, ranging from 2.0 to $4.6 \mathrm{Tg} \mathrm{N} \mathrm{yr}^{-1}$ for the year 2000. This is lower than the range 6-7 $\mathrm{Tg} \mathrm{N} \mathrm{yr}^{-1}$ used by Syakila and Kroeze (2011), but with the very large uncertainties these values are probably not significantly different.

\subsubsection{Soil processes responsible for $\mathrm{NO}$ and $\mathrm{N}_{2} \mathrm{O}$ emissions}

\section{Denitrification}

Denitrification is the major N-loss pathway for $\mathrm{N}_{\mathrm{r}}$ (Fig. 7). The ratio of the denitrification products $\mathrm{N}_{2} \mathrm{O}$ and $\mathrm{N}_{2}$ depends 
on localized environmental conditions in the soil. This microbial process, performed by archaea, bacteria or fungi, using oxidized nitrogen compounds such as nitrate or nitrite as an alternative electron acceptor in the absence of oxygen (Butterbach-Bahl et al., 2013), removes approximately 30$40 \%$ of $\mathrm{N}_{\mathrm{r}}$ inputs to watersheds (Seitzinger et al., 2006).

Microbial denitrification is a highly spatially distributed process occurring in soils, sediments or water bodies if environmental conditions become unfavourable for aerobic degradation of organic matter. It mostly occurs at aerobicanaerobic interfaces in soils, e.g. in riparian zones where lateral water flow from upstream regions provides a steady influx of nitrogen oxides as well as dissolved organic $\mathrm{C}$ to the waterlogged and oxygen $\left(\mathrm{O}_{2}\right)$-depleted soil zones in such topographic depressions. Thus, riparian areas are hotspots of denitrification (Pinay et al., 2007) as well as often hotspots of soil $\mathrm{N}_{2} \mathrm{O}$ emissions (Jungkunst et al., 2008; Butterbach-Bahl and Dannenmann, 2011). Denitrification is a heterotrophic process in which nitrate $\left(\mathrm{NO}_{3}^{-}\right)$is used as a terminal electron acceptor during the oxidation of $\mathrm{C}$ substrates (Groffman et al., 2006). Thus, at least three pre-conditions need to be fulfilled: (a) oxygen depletion, (b) availability of nitrogen oxides and (c) availability of easily degradable $\mathrm{C}$ substrates. In wastewater denitrification is the key process removing $\mathrm{NO}_{3}^{-}$, but it is also a major loss pathway of $\mathrm{N}$ fertilizers in agriculture. Loss rates of $\mathrm{N}_{2} \mathrm{O}$ from fertilized cropland due to denitrification have been reported to be up to $240 \mathrm{~kg} \mathrm{~N} \mathrm{ha}^{-1} \mathrm{yr}^{-1}$ (Barton et al., 1999), thus, potentially even exceeding fertilizer application rates.

Denitrification is activated if soils become water-saturated or water-logged, e.g. due to heavy rainfall or irrigation. The sudden increase in soil moisture, blocking macro- and micropores with soil water, decreases $\mathrm{O}_{2}$ diffusion into soil by approximately a factor of 4 . Since microbial metabolism as well as plant root respiration continues, the soil becomes anaerobic. Thus, besides being spatial highly distributed, with certain hotspots such as riparian areas in the landscape, denitrification is also temporally highly discontinuous and is a so-called "hot-moment" phenomenon (Groffman et al., 2006, 2009).

\section{Nitrification}

Biological and abiotic processes in soils are responsible for the production and consumption of $\mathrm{NO}$ and $\mathrm{N}_{2} \mathrm{O}$. Principal microbial processes leading to $\mathrm{NO} / \mathrm{N}_{2} \mathrm{O}$ production are nitrification and denitrification, and nitrifier denitrification (Fig. 7). There may be other theoretically feasible processes, which have not yet been identified in soils (Medinets et al., 2015; Schreiber et al., 2012). Chemodenitrification, the chemical decomposition of $\mathrm{NO}_{2}$, is an important source of $\mathrm{NO}$ in acid soils and soils rich in humic acids (Stevenson et al., 1970; Zumft, 1997). Reduction of nitrite $\left(\mathrm{NO}_{2}^{-}\right)$to $\mathrm{NH}_{4}^{+}$ is also known to be a source of $\mathrm{N}_{2} \mathrm{O}$ in some reduced environments (Fig. 7; Baggs, 2008)

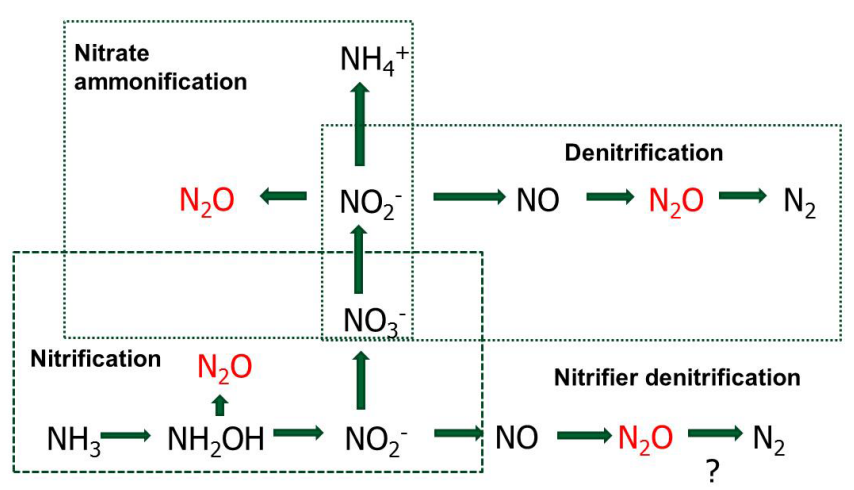

Figure 7. A schematic diagram of the microbial processes contributing to $\mathrm{N}_{2} \mathrm{O}$ production (adapted from Baggs, 2008).

Nitrification is the microbial oxidation of $\mathrm{NH}_{4}^{+}$to nitrate $\left(\mathrm{NO}_{3}^{-}\right)$, with hydroxylamine and $\mathrm{NO}_{2}^{-}$as essential intermediates. This process occurs in all soils and aqueous systems and involves a wide range of microorganisms. In the denitrification pathway $\mathrm{NO}$ and $\mathrm{N}_{2} \mathrm{O}$ are obligate intermediates, whereas in nitrification they are by-products and thought to operate when conditions are suboptimal for further oxidation to $\mathrm{NO}_{3}^{-}$(Conrad et al., 1996; Baggs, 2008). Both processes take place in the same soil microsites, but even with modern technologies such as isotopic labelling, use of microelectrodes and molecular analysis, it is difficult to unravel the detailed biological pathways responsible for NO and $\mathrm{N}_{2} \mathrm{O}$ production under different conditions (Schreiber et al., 2012). Generally, NO emissions are considered to be associated with nitrification conditions and $\mathrm{N}_{2} \mathrm{O}$ emissions with denitrification conditions.

\subsubsection{Effects of climate change on $\mathrm{NO}$ and $\mathrm{N}_{2} \mathrm{O}$ emissions}

\section{Climate change}

Microbial activity will increase with temperature if the process itself is not limited by the availability and supply of the respective substrate(s), such as easily degradable $\mathrm{C}$ and oxidized $\mathrm{N}$ compounds. If global and regional temperatures continue to increase, there is a potential for denitrification and nitrification rates also to increase. The study by C. Luo et al. (2014), for example, shows that in grassland soils undergoing experimental warming of $2{ }^{\circ} \mathrm{C}$ over a period of 10 years, key metabolic pathways related to $\mathrm{C}$ and $\mathrm{N}$ turnover accelerated. In the case of denitrification, this increase was $12 \%$. However, if summer temperatures increase whilst summer rainfall decreases, denitrification rates would decrease substantially, since anaerobic conditions - the most important environmental precondition for denitrification - are not provided. These conditions would however be favourable for $\mathrm{NO}$ and $\mathrm{N}_{2} \mathrm{O}$ emissions via nitrification. 
An additional consequence of rising temperature will be increased rates of transpiration and evaporation (Long et al., 2004). In conclusion, it can be assumed that changes in soil moisture as driven by changes in rainfall patterns and amounts and evapotranspiration fluxes will very likely dominate the overall response and overwhelm any direct temperature effects on denitrification, nitrification and $\mathrm{NO}$ and $\mathrm{N}_{2} \mathrm{O}$ emissions. Moreover, expected changes in the hydrological cycle at regional to continental scales will affect not only the seasonality of soil moisture changes, catchment and watershed hydrology, and the size and temporal expansion and shrinking of riparian zones (Pinay et al., 2007). Thus, when considering climate change effects on $\mathrm{NO}$ and $\mathrm{N}_{2} \mathrm{O}$ emissions one must include changes in rainfall (amount, frequency and seasonality), evapotranspiration and associated changes in surface and subsurface water flows and catchment-watershed hydrology in the focus (ButterbachBahl and Dannenmann, 2011).

\section{Land use}

Expected changes in climate are already triggering changes in land use and land management. The area of irrigated agricultural land is expanding quickly not only in semi-arid but also in humid temperate climates to adapt agriculture to predicted temporal water scarcity due to climate change (Trost et al., 2013). Reviewing the existing literature on irrigation effects on soil $\mathrm{N}_{2} \mathrm{O}$ emissions, Trost et al. (2013) found that in most cases irrigation increased $\mathrm{N}_{2} \mathrm{O}$ emissions in a range from +50 to $+150 \%$, which is very likely caused by increased denitrification activity in such soils. Irrigation may increase (Liu et al., 2010) or reduce NO emissions (Abalos et al., 2014), depending on the wetness of the soil.

The large-scale introduction of no-till agriculture, especially in Latin America (Abdalla et al., 2013), may affect $\mathrm{N}_{2} \mathrm{O}$ and $\mathrm{NO}$ emissions. A study by Rosa et al. (2014), which addresses denitrification activity in no-till production systems in the Argentinian pampas, suggests that increased soil aggregate stability in no-till systems, and its effects on $\mathrm{C}$ sequestration, water infiltration, soil aeration and microbial habitat provision, is the most important factor for explaining changes in denitrification activity, rather than by changes of the microbial community (Attard et al., 2011). For a cereal field in Scotland, UK, no-till increased $\mathrm{N}_{2} \mathrm{O}$ emissions, but decreased $\mathrm{NO}$ emissions, whereas tillage had the opposite effect and increased $\mathrm{NO}$ but decreased $\mathrm{N}_{2} \mathrm{O}$ emissions (Skiba et al., 2002).

\section{Atmospheric composition change}

The main component is the increasing concentration of atmospheric $\mathrm{CO}_{2}$, and in some regions increasing levels of tropospheric $\mathrm{O}_{3}$, and atmospheric deposition of $\mathrm{N}_{\mathrm{r}}$. Increasing levels of atmospheric $\mathrm{CO}_{2}$ increases water use efficiency of plant photosynthesis, resulting in increased soil moisture levels and hence increased $\mathrm{N}_{2} \mathrm{O}$ emissions by denitrification or nitrification (e.g. Kammann et al., 2008) but probably reduced NO emissions. Also rhizodeposition of easily degradable $\mathrm{C}$ compounds has been shown to increase (Singh et al., 2010 ) as a result of additional inputs of $\mathrm{N}_{\mathrm{r}}$ to soil by atmospheric deposition (i.e. the other denitrification substrate besides labile organic $\mathrm{C}$ compounds); the overall effect of atmospheric composition change on denitrification is to increase denitrification.

To predict quantitatively how climate change will influence terrestrial denitrification and nitrification rates and associated $\mathrm{NO}$ and $\mathrm{N}_{2} \mathrm{O}$ emissions, it is necessary to know both the quantities of $\mathrm{N}_{\mathrm{r}}$ used by agriculture and the effects of climate on the soil processing. The balance of evidence suggests a net increase of $\mathrm{NO}$ and $\mathrm{N}_{2} \mathrm{O}$ emissions due to the increases in $\mathrm{N}_{\mathrm{r}}$ use needed to feed a growing population and increased demand for biofuels. For $\mathrm{N}_{2} \mathrm{O}$ IPCC (2013) climate simulations, using a new set of scenarios (representative concentration scenarios RCP2.6, RCP4.5, RCP6 and RCP8.50) suggests an average increase of $\mathrm{N}_{2} \mathrm{O}$ by $1.6 \mathrm{Tg} \mathrm{N} \mathrm{N}_{2} \mathrm{O}-\mathrm{N}$ (range -1.4 to $4.5 \mathrm{Tg} \mathrm{N} \mathrm{N}_{2} \mathrm{O}-\mathrm{N}$ ) between 2010 and 2050. A similar increase in the remaining half of the 21 st century would lead to an increase in emissions by $28 \%$ over the century to $3.2 \mathrm{Tg} \mathrm{N} \mathrm{yr}^{-1}$ in 2100 . An increase in soil $\mathrm{NO}$ emissions during the 21 st century of similar magnitude to those for $\mathrm{N}_{2} \mathrm{O}$ seems likely, as emissions of both gases are primarily driven by agricultural and biofuel production. This would lead to soil emissions of NO in 2100 of $11.5 \mathrm{Tg} \mathrm{N} \mathrm{yr}^{-1}$.

It is clear that predicted changes in rainfall and regional hydrological cycles are more important than direct effects of temperature for large-scale denitrification activity. Increases in precipitation at higher latitudes appear common to many climate model projections for the later decades of this century (IPCC, 2013), but the variability in magnitude and distribution precludes clear regional quantification. Likewise the drying of the Mediterranean basin is a common feature in some climate model simulations. Such a response would decrease $\mathrm{N}_{2} \mathrm{O}$ emissions but could increase NO emissions. These expected changes are overlaid by changes in land use and land management, which are also partly triggered by climate change. Moreover, changes in atmospheric composition are indirectly feeding back on denitrification activity in soils too, e.g. by affecting plant performance and, thus, nutrient and water flows. To better understand climate change effects on regional and global denitrification and nitrification activities, multi-factorial climate (e.g. Mikkelsen et al., 2008) and land-use/land-management change experiments are needed. Such studies have still only been run for relatively short periods, which hampers the detection of interactive and nonlinear effects, and the identification of thresholds and tipping points (Luo et al., 2011). 


\section{Atmospheric processing - chemistry}

Higher temperatures increase the rates of almost all chemical conversions: the higher kinetic energies associated with warmer temperatures mean reactions proceed faster. Temperature has particularly important effects on two equilibria involving reactive nitrogen (Cox and Roffey, 1977; Feick and Hainer, 1954):

$$
\begin{aligned}
& \mathrm{PAN} \leftrightarrow \mathrm{CH}_{3} \mathrm{COO}_{2}+\mathrm{NO}_{2}, \\
& \mathrm{NH}_{4} \mathrm{NO}_{3(\mathrm{l})} \leftrightarrow \mathrm{NH}_{3(\mathrm{~g})}+\mathrm{HNO}_{3(\mathrm{~g})} .
\end{aligned}
$$

Higher temperatures push both these equilibria towards the right, i.e. resulting in thermal decomposition of gaseous peroxyacetyl nitrate (PAN: $\mathrm{CH}_{3} \mathrm{COO}_{2} \mathrm{NO}_{2}$ ) and ammonium nitrate $\left(\mathrm{NH}_{4} \mathrm{NO}_{3}\right)$ aerosol particles, effectively reducing the atmospheric lifetimes of these two species. The impacts of $21 \mathrm{st}$ century climate change on global atmospheric composition, via reaction (Eq. 6), have been investigated by Doherty et al. (2013). For a temperature increase of $+3 \mathrm{~K}$ (typical for 2100 relative to present day), the PAN lifetime in the troposphere approximately halves (from 4 to $2.5 \mathrm{~h}$ at mean surface temperatures of $290 \mathrm{~K}$; and from 6 to 3 months at mid- to upper-tropospheric temperatures of $250 \mathrm{~K}$ ). As PAN is a major component of tropospheric $\mathrm{NO}_{y}$, climate change may significantly reduce the size of the $\mathrm{NO}_{y}$ reservoir, reducing the long-range (or intercontinental) transport of $\mathrm{NO}_{y}$ (Doherty et al., 2013).

Liao et al. (2006) find that climate change effects (specifically the SRES A1B scenario from 2000 to 2050) lead to reduced concentrations of $\mathrm{NH}_{4}^{+}$aerosols over East Asia and attribute this to temperature increases acting via Eq. (7). Similar results were found over the US (Pye et al., 2009).

Changes in the stratospheric source of $\mathrm{HNO}_{3}$ are also likely as a consequence of a changing climate. Much like the predicted increase in tropospheric $\mathrm{O}_{3}$ from enhanced stratosphere-troposphere exchange (STE), driven by a more intense Brewer-Dobson circulation, the stratospheric $\mathrm{O}_{3}$ enters the troposphere with some $\mathrm{NO}_{y}$ as $\mathrm{HNO}_{3}$. This is a small source currently estimated to be $\sim 1 \mathrm{Tg} \mathrm{Nyr}^{-1}$, but STE is projected to increase by $50-100 \%$ over the 21 st century, so this $\mathrm{NO}_{y}$ source may approximately double. Stratospheric $\mathrm{NO}_{y}$ and $\mathrm{O}_{3}$ may show different trends, so it may be more complicated than just knowing the STE air mass flux (most models just add $\mathrm{NO}_{y}$ with a fixed ratio to $\mathrm{O}_{3}$ ).

\subsection{Lightning-climate interactions}

Lightning NO is an important natural source of tropospheric $\mathrm{NO}_{x}$, especially the tropical upper troposphere (Schumann and Huntrieser, 2007). Nitric oxide (NO) is formed following the dissociation of molecular oxygen and $\mathrm{N}$ by the lightning discharge in air. Atmospheric composition is modified as described in the companion paper by Monks et al. (2015).

The effects of climate change on lightning and $\mathrm{NO}_{x}$ production have been investigated by Toumi et al. (1996), and by
Reeve and Toumi (1999) suggesting increases in both lightning and $\mathrm{NO}_{x}$ production. The estimates of increased $\mathrm{NO}_{x}$ production in a warmer climate are rather variable and range from 4 to $60 \%$ per kelvin (surface temperature change), Schumann and Huntrieser, 2007; Williams, 2005). More recent analyses by Romps et al. (2014) based on the convective available potential energy (CAPE) and precipitation rate indicate values of $12 \pm 5 \% \mathrm{~K}^{-1}$.

Taking a value towards the lower end of the range of reported temperature responses, of $10 \% \mathrm{~K}^{-1}$ and a temperature change of $4 \mathrm{~K}$ by 2100 , yields an increase in lightning

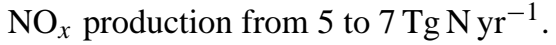

\section{Organic nitrogen}

Gaseous organic nitrogen exists in the atmosphere in both oxidized (peroxy acetyl nitrate PAN, and related compounds) and reduced forms, including amines, amino acids and urea. Organic nitrogen also occurs in particulate matter and in rain and snow; from the methodology for chemical analysis it is not always clear whether the organic nitrogen was in reduced or oxidized form. The oxidized gaseous forms, and PAN especially, are important as a reservoir of ozone precursors for photochemical oxidant formation (Singh and Hanst, 1981), while interest in the gaseous reduced forms and ON in aerosols and precipitation is primarily through their contribution to nitrogen deposition (Jickells et al., 2013).

Organic nitrogen in the atmosphere has been reviewed recently by Cape et al. (2011), Cornell et al. (2011) and Jickells et al. (2013). These reviews cover available measurements, atmospheric cycling, and provide a technical discussion on analytical methods, their comparability and statistical caveats for data treatment. In this section a general description of atmospheric ON, its sources, relevant properties and relations to the $\mathrm{N}$ cycle and the likely effects of changes this century is given. Gaseous oxidized organic nitrogen compounds are treated separately, as the literature and motivation are distinct.

\subsection{Atmospheric relevance}

Organic nitrogen is a ubiquitous component of the atmosphere, mainly found in aerosols and precipitation, although present also in the gas phase (Cape et al., 2011; Cornell et al., 2011; Jickells et al., 2013). Atmospheric concentration data for the aerosol fraction in literature often refer to the water-soluble fraction of ON (WSON), more frequently investigated as it is considered to be more bioavailable (Seitzinger and Sanders, 1999) and climate relevant. Aerosol WSON atmospheric concentrations range from a few to few tens of nmol $\mathrm{N} \mathrm{m}^{-3}$ in a selection of remote sites by Jickells et al. (2013), reaching concentrations as high as $\sim 150 \mathrm{nmol} \mathrm{N} \mathrm{m}^{-3}$ in the Po Valley (Montero-Martinez et al., 2014) and up to $2 \mu \mathrm{mol} \mathrm{N} \mathrm{m}{ }^{-3}$ at Qingdao (China) (Shi et al., 
2011). The above aerosol concentrations determine WSON in rainwater ranging between $5 \mu \mathrm{mol} \mathrm{L}-1$, in remote regions, and $>100 \mu \mathrm{mol} \mathrm{L}^{-1}$ as measured in China (Cornell et al., 2011).

The water-soluble fraction of $\mathrm{ON}$ contribution to total $\mathrm{N}$ in aerosol and rainwater has been investigated in a number of studies, with results ranging from a few percent to more than $40 \%$ (Cornell et al., 2011). Jickells et al. (2013) report a collection of rainwater WSON data sets from around the world from the studies of Cornell et al. $(2003,2011)$ and Zhang et al. (2012), resulting in an average ON contribution of $24 \%$. Similar contributions, ranging from 19 to $26 \%$, have been observed for aerosols in many other studies (Zhang et al., 2002; Chen et al., 2010; Lesworth et al., 2010; Kunwar and Kawamura, 2014; Miyazaki et al., 2014; Montero-Martinez et al., 2014). Nevertheless, lower WSON/TN contributions have been also reported: $6 \%$ in Delaware, USA (Russell et al., 2003), $13 \%$ in Crete (Violaki and Mihalopoulos, 2010), $16 \%$ in the outflow from northeast India over the Bay of Bengal (Srinivas et al., 2011) and $10 \%$ in paired urban-rural sites in Georgia (Rastogi et al., 2011). Higher contributions seem, instead, typical of China (Shi et al., 2011; Zhang et al., 2012), likely due to the use of organic manures and urea as fertilizers in agriculture (Jickells et al., 2013).

It is worth highlighting that in one of the few studies in which total ON (and not WSON) was measured, the ON / TN ratio was of the order of $70 \%$ (western North Pacific in summer) (Miyazaki et al., 2010), suggesting an important contribution from water-insoluble ON. Russell et al. (2003) also showed an important fraction of aerosol ON in waterinsoluble form. Other investigators ( $\mathrm{Li}$ and $\mathrm{Yu}, 2004$; Duan et al., 2009) which measured the total ON have not confirmed such a result. Finally, the model approach of Kanakidou et al. (2012) estimated ON as $26 \%$ of TN deposition, globally.

These numbers provide an insight into the importance of atmospheric $\mathrm{ON}$ in the $\mathrm{N}$ cycle, even though a full understanding is far from being achieved. In particular, $\mathrm{ON}$ can be considered important in the long-range transport of $\mathrm{N}$ (e.g. Singh and Hanst, 1981; Gorzelska and Galloway, 1990; Neff et al., 2002; Matsumoto and Uematsu, 2005) because its removal processes tend to be less effective than those for nitrate and ammonium, which are generally deposited closer to their sources (Cornell et al., 2011).

At least a fraction of ON is known to be bioavailable (Timperley et al., 1985; Peierls and Paerl, 1997; Seitzinger and Sanders, 1999); therefore, its deposition can provide nutrients for land and marine ecosystems. Nevertheless, the effects of ON on the surface ocean are unclear due to the large uncertainty in the sources and magnitudes of deposition. Even less is known about the potential human and ecosystem toxicity of ON (Paumen et al., 2009).

Recently, atmospheric ON has received attention because of its light-absorbing properties (Desyaterik et al., 2013). Reactions leading to the formation of ON compounds in aerosol particles or evaporating droplets have been indicated as po- tentially important for the formation of atmospheric brown carbon (Nozière et al., 2007, 2009; Shapiro et al., 2009; Nguyen et al., 2012; Powelson et al., 2014; Lee et al., 2013).

\subsection{Chemical composition}

Atmospheric $\mathrm{ON}$ is a subset of the organic carbon and, in comparison with the latter, is a complex mixture of compounds with different properties and origin (e.g. Saxena and Hildemann, 1996; Jacobson et al., 2000; Neff et al., 2002). Complementary to the total ON (or WSON) determination approach, many studies have focused on measuring the concentration of individual $\mathrm{N}$ compounds or groups of compounds in air, aerosols or rainwater. Given the difficulties of measuring total $\mathrm{ON}$, this approach is the usual course in the gas phase.

Although this approach will never account for the whole $\mathrm{ON}$, it can be useful in providing insights to sources and to clarify the contribution of single species to ON. Compounds analysed in individual studies include amines, amino acids, urea, nitrophenols, alkyl amides, N-heterocyclic alkaloids and organic nitrates (Cape et al., 2011; Jickells et al., 2013), none of which resulted in dominating the ON composition. This suggests that a large fraction of $\mathrm{ON}$ is associated with high molecular weight polymers, constituting the humic-like materials (HULIS) (Chen et al., 2010).

This approach has shown that in certain environments and conditions, some compounds make up a consistent fraction of atmospheric ON. For instance, amino acids have been reported to account for up to $50 \%$ in Tasmania (Mace et al., 2003a), while Facchini et al. (2008) report dimethyl- and diethyl-amines contributing $35 \%$ of aerosol ON over the eastern North Atlantic Ocean. On the contrary, in other studies these are only minor components (e.g. Mace et al., 2003b, c; Müller et al., 2009; Violaki and Mihalopoulos, 2010). Urea was also shown as an important contributor ( $>20 \%$ ) by Cornell et al. (2001) and Mace et al. (2003a) in Hawaii and Tasmania, but it was reported as a minor ON component in other sites (Mace et al., 2003b, c). Recently, Zhang et al. (2012) showed that urea represents more than $40 \%$ of rainwater WSON in China, where urea is widely used as a fertilizer.

Recently, ultra-high-resolution mass spectrometry has provided new insights into $\mathrm{ON}$ chemical composition in aerosol and rainwater. $\mathrm{N}$-containing molecules have been reported, for instance, by Rincon et al. (2012), Cottrell et al. (2013), O'Brien et al. (2013), Zhao et al. (2013), and Kourtchev et al. (2014), accounting for 40 to more than $50 \%$ of the total identified molecules in their samples, for a total of thousands of compounds. These studies suggest that $\mathrm{ON}$ is made of both oxidized (organonitrates, nitroxyorganosulfates) and reduced (amines, imines, imidazoles) $\mathrm{N}$ species. Altieri et al. $(2009,2012)$ found similar results, with more than two-thirds of the detected ON compounds containing reduced nitrogen. Moreover, they observed significant chemical composition differences between marine and conti- 
nental samples, concluding that, although the concentrations and percent contribution of WSON to total $\mathrm{N}$ are fairly consistent across diverse geographic regions, the chemical composition of WSON varies strongly as a function of source region and atmospheric environment. LeClair et al. (2012) reported that approximately $63 \%$ of the CHNO and $33 \%$ of CHNOS compounds observed in Fresno radiation fog samples exhibited a loss of $\mathrm{HNO}_{3}$, suggesting that besides organonitrates, there might be other $\mathrm{N}$-containing functional groups present, such as amines, imines, and nitro groups.

These techniques detect $\mathrm{ON}$ compounds in a wide range of molecular weights with carbon number between 2 and 35 (Zhao et al., 2013; Cottrell et al., 2013). Nevertheless, Chen et al. (2010) have demonstrated that $\mathrm{N}$-containing molecules can have masses greater than $1 \mathrm{kDa}$.

\subsection{Organic nitrogen sources}

The complexity of ON chemical composition is reflected by its sources. ON source attribution was tentatively achieved in different studies based on size distribution, correlation with source tracers, multivariate analysis and isotopic ratios.

Many investigators report a significant spatial or temporal correlation between $\mathrm{ON}$ and inorganic $\mathrm{N}$ in aerosol and rainwater samples, with ON constituting roughly a quarter of total $\mathrm{N}$ in many environments (Cape et al., 2004; Zhang et al., 2012). Considering that inorganic $\mathrm{N}$ emissions are globally dominated by anthropogenic sources, ON has likely an important anthropogenic component (Zhang et al., 2012; Jickells et al., 2013). Many papers highlight important anthropogenic ON sources (e.g. Cornell et al., 2001; Mace et al., 2003c; Chen et al., 2010; Iinuma et al., 2010; Rastogi et al., 2011; Zamora et al., 2011; Zhang et al., 2012; Kourtchev et al., 2014; Violaki and Mihalopoulos, 2010; Cape et al., 2004; Bencs et al., 2009). More in detail, ON seems to present higher correlation with $\mathrm{NH}_{4}^{+}$than $\mathrm{NO}_{3}^{-}$(Zhang et al., 2012; Cape et al., 2004; Srinivas et al., 2011). This points to an atmospheric processing of ON similar to that of reduced nitrogen, or to similar sources (Jickells et al., 2013). Indeed, several papers evidence $\mathrm{ON}$ formation processes via interactions between organic matter and reduced $\mathrm{N}$ (ammonia, amine compounds or HNCO and related gases) like Nguyen et al. (2012), Lee et al. (2013) and O'Brien et al. (2013). Nevertheless, also ON formation through $\mathrm{NO}_{x}$ or $\mathrm{NO}_{3}$ radical chemistry is reported in the literature (e.g. Zhao et al., 2013; Fry et al., 2013).

Notwithstanding the very likely global dominance of anthropogenic sources, natural sources of $\mathrm{ON}$ have been reported both in the marine (Spokes et al., 2000; Cornell et al., 2011; Mace et al., 2003a; Facchini et al., 2008; Müller et al., 2009; Miyazaki et al. 2010; Kunwar et al., 2014) and continental (Miyazaki et al., 2014; Kieloaho et al., 2013; Laitinen et al., 2014) environments.

As for formation processes, primary $\mathrm{ON}$ sources have been reported associated with soil suspension (Chen et al., 2010),

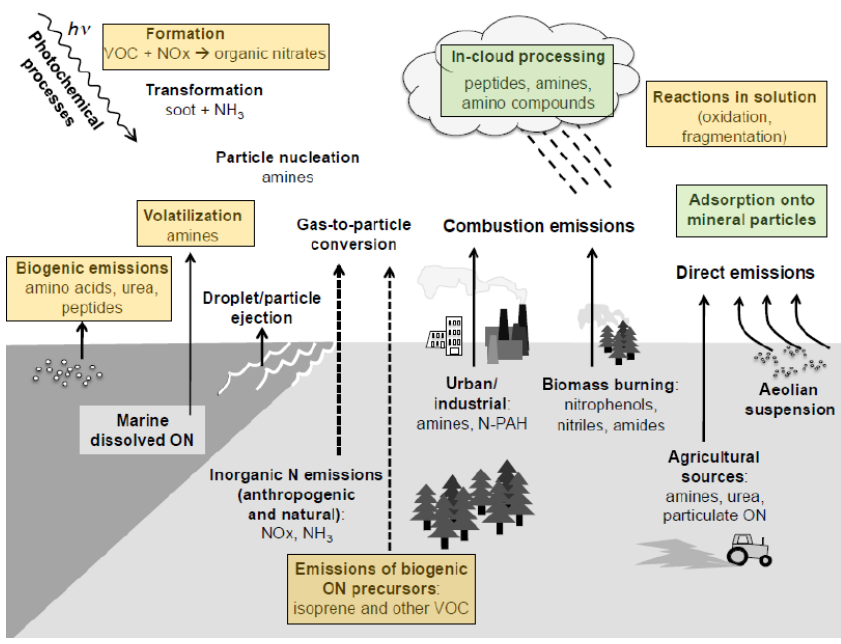

Figure 8. Processes where increased temperatures would be expected to increase atmospheric $\mathrm{ON}$ (orange) or decrease $\mathrm{ON}$ (green); no colour code implies uncertain effects. Adapted from Jickells et al. (2013).

sea spray (Miyazaki et al., 2010; Barbaro et al., 2011; Scalabrin et al., 2012) and biomass burning (Desyaterik et al., 2013; Zamora et al., 2011; Mace et al., 2003b; Srinivas et al., 2011; Violaki and Mihalopoulos, 2011). Evidence of the importance of secondary $\mathrm{ON}$ formation has been presented for a range of environments, involving a number of precursors (De Haan et al., 2011; Nguyen et al., 2012; Rincon et al., 2012; Fry et al., 2013; Lee et al., 2013; Miyazaki et al., 2014; O'Brien et al., 2013; Zhao et al., 2013; Kourtchev et al., 2014). Furthermore, organic N, amines in particular, is known to play a role in atmospheric new particle formation (Murphy et al., 2007; Kurtén et al., 2008; Smith et al., 2010; Kirkby et al., 2011).

Concluding, Jickells et al. (2013) summarize atmospheric ON sources in (1) soil dust, including in this source both ON associated with soil organic matter itself and the adsorption of ON onto dust particles; (2) biomass burning; (3) marine emission both direct and via emissions of gaseous precursors; and (4) anthropogenic and agricultural sources.

\subsection{Effects of future climate change on $\mathrm{ON}$}

Although predicting the effects of future changes in climate on $\mathrm{ON}$ is uncertain, given the current state of knowledge of the relative contributions of the different sources of $\mathrm{ON}$ in the atmosphere, some general points can be made:

1. Observed spatial and temporal patterns of ON concentrations and deposition correlate positively with those of $\mathrm{NO}_{y}$ and $\mathrm{NH}_{x}$, and it seems therefore likely that the projected increases in inorganic $\mathrm{N}_{\mathrm{r}}$ will be associated with increases in ON. 
2. For material derived from resuspension of soils, periods of prolonged drought and/or increased wind speeds would lead to greater amounts of airborne material than at present.

3. For material derived from biomass burning, future patterns of biomass burning (whether natural, from increased drought, or man-made, from changes in land use) will affect $\mathrm{ON}$ emissions.

4. Increases in average temperatures would be expected to lead to increased atmospheric concentrations of volatile and semi-volatile organic compounds, including ON species, and in particular amines and urea, both of which are related to agricultural practices. Increased emissions of volatile organic compounds (VOCs) would provide greater substrate concentrations for reactions which form atmospheric ON. Increased sea-surface temperatures would also lead to increased volatilization of ON from the sea surface layer.

5. Increases in the oxidized nitrogen $\left(\mathrm{NO}_{y}\right)$ content of the atmosphere would lead to faster reaction and conversion of organic matter into N-containing material, probably in the aerosol phase, leading in turn to increased aerosol concentrations of ON. Similarly, increased oxidizing capacity would lead to faster conversion of hydrocarbons into oxidized organic matter, which would be expected to act as a substrate for subsequent reaction with both reduced and oxidized forms of $\mathrm{N}$.

6. Changes in agricultural practice could lead to large changes in $\mathrm{ON}$ emissions, e.g. changes in the use of urea as a fertilizer, or changes in the management of animal wastes.

The evidence, while largely qualitative, suggests increases in the absolute quantity of $\mathrm{ON}$ in the atmosphere due to changes in climate and the amount of $\mathrm{N}_{\mathrm{r}}$ fixed by natural and anthropogenic activity. The $\mathrm{ON}$ processes which are sensitive to changes in climate and land use are summarized in Fig. 8. However, the knowledge of atmospheric processing and lifetimes of the chemical components precludes quantitative estimates of the changes this century.

\subsection{Peroxyacetyl nitrate (PAN), peroxypropionyl nitrate (PPN) and peroxymethacryloyl nitrate (MPAN)}

Acyl peroxynitrates (APNs) are produced in the boundary layer and lower free troposphere during the photochemical oxidation of volatile organic compounds (VOCs) in the presence of $\mathrm{NO}_{x}$ (Cox and Roffey, 1977). The mixing ratios of these compounds are dominated by PAN with measured values commonly in the range 0.1 to $3 \mathrm{ppbV}$ in Europe and North America (McFadyen and Cape, 2005; Parrish et al., 2004), with PAN contributing $80-90 \%$ of the speciated APN measurements (Roberts, 1990). In a study of mixing ratios and fluxes of speciated APNs over a Ponderosa pine forest, PAN values were in the range 200 to 500 pptv while PPN and MPAN values were generally 20 to 50 pptv (Wolfe et al., 2009). A particular interest in APNs has been their role as an atmospheric reservoir of $\mathrm{NO}_{y}$. APNs are subject to thermal decomposition, being stable in the cool upper troposphere and yet may decompose at lower altitudes and higher temperatures (Parrish et al., 2004). Through these processes APNs can transport $\mathrm{NO}_{y}$ over substantial distances and contribute to ozone formation remotely from the $\mathrm{NO}_{x}$ sources.

The temperature sensitivity of PAN through thermal decomposition makes these compounds sensitive to changes in climate as noted in Sect. 5, but important effects also appear at the atmosphere-surface interface over terrestrial ecosystems. Direct measurements of PAN deposition to a grassland were made by Doskey et al. (2004), who showed that thermal decomposition was a greater removal mechanism within the boundary layer than dry deposition to the grassland. Wolfe et al. (2009) reported flux measurements of APNs, above a Ponderosa pine canopy in California, showing daytime deposition fluxes of peroxyacetyl nitrate and deposition velocities peaking at $\sim 5 \mathrm{~mm} \mathrm{~s}^{-1}$ at midday and very small deposition velocities at night $\left(\sim 1 \mathrm{~mm} \mathrm{~s}^{-1}\right)$. Daytime deposition velocities of PPN were larger peaking at $13 \mathrm{~mm} \mathrm{~s}^{-1}$ and were similar to those of PAN at night, while deposition velocities of MPAN were similar to those of PAN. In the case of PPN and MPAN the fluxes were an order of magnitude smaller than those of PAN; thus the overall flux was dominated by PAN. The dominant site of uptake within plant canopies for PAN appears to be stomata, from both laboratory and field studies. However, night-time deposition values suggest that cuticular uptake contributes to the total deposition flux and, on average, may be responsible for between 20 and $30 \%$ of the total deposition.

Measurements over Ponderosa pine by Farmer and Cohen (2008) suggest that in-canopy chemical production of $\mathrm{OH}$ substantially modifies the fluxes of $\mathrm{NO}_{y}$ and VOC species, within and above the canopy. Further it is clear from their work that the exchange of $\mathrm{O}_{3}, \mathrm{NO}_{x}$ and biogenic volatile organic compounds is regulated by solar radiation and depends exponentially on temperature, but predictions of the net effect of expected changes in climate have not been quantified. The effects of climate on PAN, PPN and MPAN may change the fate and lifetimes of these species in plant canopies, but since their contribution to nitrogen budgets at regional scales is small, the impact on the wider global nitrogen cycle is limited.

\section{Effects of global change on ecosystem-atmosphere exchange of reactive nitrogen}

A wide range of atmospheric $\mathrm{N}_{\mathrm{r}}$ compounds (reduced $\mathrm{N}_{\mathrm{r}}$ including gaseous $\mathrm{NH}_{3}$, amines and aerosol $\mathrm{NH}_{4}^{+}$; and ox- 
idized $\mathrm{N}_{\mathrm{r}}$ including gaseous $\mathrm{NO}, \mathrm{NO}_{2}, \mathrm{HONO}, \mathrm{HNO}_{3}, \mathrm{PAN}$, $\mathrm{PPN}$ and aerosol $\mathrm{NO}_{3}^{-}$) are emitted by, and/or dry-deposited to, the Earth's surface (vegetation, soils, water bodies, builtup areas) (Flechard et al., 2011). The sign and magnitude of their exchange fluxes are governed not only by their chemical properties but also by meteorological, physical, chemical and biological processes. For many of these species (e.g. $\mathrm{NH}_{3}$, $\mathrm{HONO}, \mathrm{NO}_{2}$ ) the exchange can be bi-directional (Flechard et al., 2013; Oswald et al., 2013; Neirynck et al., 2007), with emissions occurring when the surface potential exceeds the atmospheric concentration, or vice versa. Soils have recently been shown to be a source of HONO to the atmosphere ( $\mathrm{Su}$ et al., 2011).

All transfer processes between the atmosphere and the surface (vertical turbulent transport, ecosystem air column chemistry, surface-vegetation sink or source strength) are potentially affected by global change, not just through altered climate and elevated $\mathrm{CO}_{2}$ and the knock-on effects on global vegetation and the ocean, but also (i) through changes in the mixing ratios of other pollutants such as $\mathrm{O}_{3}$ and $\mathrm{SO}_{2}$ that affect stomatal function and/or surface chemical sinks; (ii) through changes in land use, land cover and agricultural as well as silvicultural practices; and even (iii) through the feedback of elevated $\mathrm{N}_{\mathrm{r}}$ deposition on ecosystem functioning.

\subsection{Impacts on processes regulating surface $\mathbf{N}_{\mathbf{r}}$ sink-source strength}

\subsubsection{Vertical atmospheric transport}

Compounds whose deposition rates are particularly sensitive to atmospheric turbulence include those for which vegetation is a perfect sink, including nitric acid, and those contained in aerosols. Thus, surface wind speed, friction velocity, atmospheric stability and surface roughness control the rates of vertical turbulent transport of $\mathrm{N}_{\mathrm{r}}$ trace gases and aerosols through the surface layer and within the canopy. The aerodynamic $\left(R_{\mathrm{a}}\right)$ and viscous sublayer $\left(R_{\mathrm{b}}\right)$ resistances to dry deposition are both inversely proportional to the friction velocity (Monteith and Unsworth, 2013). A comparison over the period 1988-2010 of recent linear trends in global surface wind speeds from satellite data, from in situ data and from atmospheric reanalyses, showed (i) a pattern of positive and negative trend bands across the North Atlantic Ocean and positive trends along the west coast of North America and (ii) a strengthening of the Southern Ocean winds, consistent with the increasing trend in the Southern Annular Mode and with observed changes in wind stress fields (Fig. 2.38 in IPCC, 2013). The decadal trends in surface winds on land were mostly of the order of 0 to $+0.2 \mathrm{~m} \mathrm{~s}^{-1}$ decade $^{-1}$, with large areas of the South Pacific experiencing increases of up to $+0.5 \mathrm{~m} \mathrm{~s}^{-1}$ decade $^{-1}$. Future trends in wind speed are unclear, but it is clear that increases of such magnitudes en- hance atmospheric dry removal rates and shorten pollutant atmospheric lifetimes.

Similarly, changes in land cover and associated surface roughness are likely to affect the atmospheric lifetime of gases and aerosol compounds alike. Large-scale deforestation, for example, would reduce the deposition rate of aerosol significantly, while changes in crop types and tree species would have more subtle but potentially important effects. For example, Davidson et al. (1982) showed that aerosol deposition rates to different grass species could differ by a factor of 10 , in response to the microstructures (e.g. hairs) of the leaves.

\subsubsection{Stomatal exchange}

The flux of gaseous $\mathrm{N}_{\mathrm{r}}$ pollutants into or out of substomatal cavities of vascular plants is controlled primarily by the stoma-atmosphere concentration gradient and by stomatal conductance $\left(G_{\mathrm{s}}\right)$ (Baldocchi et al., 1987). Free-air carbon dioxide enrichment (FACE) experiments have suggested that elevated $\mathrm{CO}_{2}$ concentrations result in a substantial reduction in ecosystem-scale $G_{\mathrm{S}}$ (typically -20 to $-30 \%$ ) (Ainsworth and Rogers, 2007), while the projected elevations in tropospheric $\mathrm{O}_{3}$ will also reduce $G_{\mathrm{s}}$ by typically 10 to $20 \%$ (Wittig et al., 2007). The combined impacts on $G_{\mathrm{s}}$ of elevated $\mathrm{CO}_{2}$ and $\mathrm{O}_{3}$ in a future climate are less clear, however, due to nonlinear interactions between plant responses to $\mathrm{CO}_{2}$ and $\mathrm{O}_{3}$. For example, the $\mathrm{CO}_{2}$-induced reduction in $G_{\mathrm{s}}$ helps alleviate future $\mathrm{O}_{3}$ plant damage by mitigating stomatal phytotoxic $\mathrm{O}_{3}$ uptake (Sitch et al., 2007).

Rising temperatures will on the other hand also impact $G_{\mathrm{s}}$ through a further reduction in stomatal opening under heat waves, or conversely through an increase in $G_{\mathrm{S}}$ in colder climates and an extension of the growing season. Changes in precipitation patterns will however likely affect $G_{\mathrm{s}}$ to a larger extent than temperature if they result in more frequent droughts during the growing season. The $\mathrm{N}_{\mathrm{r}}$ species whose dry deposition is most affected by changes in $G_{\mathrm{s}}$ is probably $\mathrm{NO}_{2}$, due to its low affinity for non-stomatal sinks (Flechard et al., 2011), but the effect could also be significant for waterinsoluble organic $\mathrm{N}$ compounds such as peroxyacyl nitrates (PANs).

In the specific case of $\mathrm{NH}_{3}$, unlike other $\mathrm{N}_{\mathrm{r}}$ species, another major control of the stomatal flux is the stomatal compensation point (Meyer, 1973), i.e. the leaf-level $\mathrm{NH}_{3}$ concentration that reflects the thermodynamic equilibrium with apoplastic $\mathrm{NH}_{4}^{+}$, which itself results from cellular exchange and the balance of cytoplasmic consumption and production (Farquhar et al., 1980; Massad et al., 2010b). The combined temperature-dependent solubility (Henry's law) and dissociation constants result in an effective $Q_{10}$ of 3-4 (Sutton et al., 2013b), which would see the $\mathrm{NH}_{3}$ compensation point approximately double with a temperature increase of $5 \mathrm{~K}$. This is the same effect that will increase emissions from agricultural point sources in a future climate (cf. Sect. 4.1.1). 
For vegetation this effect only holds, however, if the emission potential represented by the apoplastic $\Gamma$ ratio $(\Gamma=$ $\left[\mathrm{NH}_{4}^{+}\right] /\left[\mathrm{H}^{+}\right]$) remains constant. Ecosystem modelling (e.g. Riedo et al., 2002) suggests that variations in apoplastic $\left[\mathrm{NH}_{4}^{+}\right]$might be expected in response to global change, e.g. with rising temperature and $\mathrm{CO}_{2}$ affecting primary productivity and soil-plant $\mathrm{N}$ cycling. Apoplastic $\mathrm{pH}$ itself could also be affected by global change; a doubling of $\mathrm{CO}_{2}$ (from 350 to $700 \mathrm{ppm}$ ) can alkalinize the apoplast by $0.2 \mathrm{pH}$ units (Felle and Hanstein, 2002); similarly, droughts can induce increased apoplastic alkalinity by a few tenths of a $\mathrm{pH}$ unit (Sharp and Davies, 2009; Wilkinson and Davies, 2008). Because nitric oxide (NO) is an important internal signaling compound that is also released in response to ozone exposure (Velikova et al., 2005; Ederli et al., 2006), increased ozone exposure in a future chemical climate might lead to elevated compensation points for NO. This NO source is currently not usually represented in exchange models.

\subsubsection{Non-stomatal plant surfaces}

Vegetation surfaces other than stomatal apertures (leaf cuticle, stems, bark of tree trunk and branches, also senescent leaves) are generally considered efficient sinks for $\mathrm{NH}_{3}$ and especially $\mathrm{HNO}_{3}$, particularly so if these surfaces are wet from rain or dew. Soluble $\mathrm{N}_{\mathrm{r}}$ gases will readily be taken up by surface water films, although their affinity for $\mathrm{NH}_{3}$ is expected to decrease as $\mathrm{pH}$ increases beyond 7 (Walker et al., 2013), or if the $\mathrm{NH}_{x}$ accumulated in surface wetness leads to a saturation effect, reducing the sink strength (Jones et al., 2007). The atmospheric $\mathrm{SO}_{2}$ to $\mathrm{NH}_{3}$ molar ratio or the total acids $\left(2 \cdot \mathrm{SO}_{2}+\mathrm{HNO}_{3}+\mathrm{HCl}\right)$ to $\mathrm{NH}_{3}$ ratio have been used in some inferential or chemical transport models (CTMs) to scale non-stomatal resistance to surface $\mathrm{NH}_{3}$ deposition (Massad et al., 2010a; Simpson et al., 2012).

Chemical composition and size of the wetness pool are thus key to the $\mathrm{N}_{\mathrm{r}}$ gas removal efficiency (Flechard et al., 1999). It follows that global changes affecting the frequency and intensity of rain or dew, the subsequent evaporation rate of surface water, and the relative abundances of atmospheric alkaline compounds $\left(\mathrm{NH}_{x}\right.$, amines from agriculture; base cations from sea spray and soil erosion) versus acidic species $\left(\mathrm{NO}_{y}, \mathrm{SO}_{x}, \mathrm{HCl}\right.$ from traffic, household and industrial sources) are likely to affect non-stomatal sink strengths for most water-soluble $\mathrm{N}_{\mathrm{r}}$ species. Rising atmospheric $\mathrm{CO}_{2}$ itself will acidify rainfall and any plant or terrestrial surface wetness, as well as freshwater and the ocean. As an illustration, the $\mathrm{pH}$ of pure water in equilibrium with ambient $\mathrm{CO}_{2}$ at $15^{\circ} \mathrm{C}$ is 5.60 for current (399.5 ppm) $\mathrm{CO}_{2}$ concentrations; this would drop to 5.59, 5.53, 5.48 and 5.41 for the $2100 \mathrm{CO}_{2}$ levels, predicted in the representative concentration pathway scenarios, of $420.9 \mathrm{ppm}$ (RCP2.6), $538.4 \mathrm{ppm}$ (RCP4.5), 669.7 ppm (RCP6.0) and 935.9 (RCP8.5), respectively (IPCC, 2013). In real solutions, buffering effects could mitigate the impact of $\mathrm{CO}_{2}$, but global ocean surface
$\mathrm{pH}$ projections for 2100 do range from 8.05 (RCP2.6) to 7.75 (RCP8.5), versus 8.1 currently, which will mitigate the temperature-induced increase in sea $\mathrm{NH}_{3}$ emissions.

Global atmospheric emission projections for $\mathrm{NO}_{x}$ and $\mathrm{NH}_{3}$ for the year 2100 mostly range from around 15 to $75 \mathrm{Tg} \mathrm{Nyr}^{-1}$ and from around 45 to $65 \mathrm{Tg} \mathrm{Nyr}^{-1}$, respectively, compared with similar current emissions levels of around $40 \mathrm{Tg} \mathrm{Nyr}^{-1}$ for both; those for $\mathrm{SO}_{2}$ emissions mostly range from around 15 to $40 \mathrm{Tg} \mathrm{S} \mathrm{yr}^{-1}$ in 2100 , versus around $55 \mathrm{Tg} \mathrm{Syr}^{-1}$ currently (van Vuuren et al., $2011 \mathrm{a}, \mathrm{b})$. If one defines the global emission ratio $\left(2 \cdot \mathrm{SO}_{2}+\right.$ $\mathrm{NO}_{x}$ ) $/ \mathrm{NH}_{3}$ (on a molar basis) as a proxy for global atmospheric acidity-alkalinity, this yields a current global value of around $2.2 \mathrm{~mol} \mathrm{~mol}^{-1}$, while values based on 2100 emission projections range from 0.4 to $2.4 \mathrm{~mol} \mathrm{~mol}^{-1}$, with a mean value of $1.2 \mathrm{~mol} \mathrm{~mol}^{-1}$, i.e. a decrease of the ratio of $45 \%$. If, as suggested by Sutton et al. (2013b), a global temperature rise of $5 \mathrm{~K}$ induces an additional - and generally unaccounted for - increase of $42 \%$ in global $\mathrm{NH}_{3}$ emissions (on top of those attributed to increased anthropogenic activities), the reduction in the ratio is $61 \%$. For Europe, where emission reductions are likely to continue for $\mathrm{SO}_{2}$ and $\mathrm{NO}_{x}$, by $75-90 \%$ and by $65-70 \%$, respectively, by the year 2050 , and with more or less constant $\mathrm{NH}_{3}$ emissions (Engardt and Langner, 2013; Simpson et al., 2014), the ratio would drop by $75 \%$ from around 2.3 to $0.6 \mathrm{~mol} \mathrm{~mol}^{-1}$. The resulting drop in acidity of water films on terrestrial plant surfaces (also reflected in projected reductions in acid deposition see e.g. Lamarque et al., 2013) is expected to reduce nonstomatal $\mathrm{NH}_{3}$ uptake significantly; it is a direct consequence of mitigation policies likely being implemented throughout the world for $\mathrm{SO}_{x}$ and $\mathrm{NO}_{x}$ emissions, but not for $\mathrm{NH}_{3}$ except in very few countries.

This first-order estimate in the acidity ratio ignores nonlinearities caused by a change in the lifetime of individual atmospheric pollutants in response to climate and composition change. Rising temperatures would enhance chemical reaction rates on leaf surfaces as well as in the atmosphere (e.g. $\mathrm{SO}_{2}$ oxidation to $\mathrm{SO}_{4}^{2-}$ ), also affecting $\mathrm{pH}$, but perhaps more significantly, a warming would favour the partitioning of dissolved species in water films $\left(\mathrm{NH}_{3}, \mathrm{SO}_{2}\right)-$ and of volatile $\mathrm{N}_{\mathrm{r}}$-containing aerosols (e.g. $\mathrm{NH}_{4} \mathrm{NO}_{3}, \mathrm{NH}_{4} \mathrm{Cl}$ ) towards the gas phase. The non-stomatal surface resistance to $\mathrm{NH}_{3}$ deposition has been shown over grassland to be both relative humidity- and temperature-dependent, roughly doubling with every additional $5 \mathrm{~K}$ (Flechard et al., 2010), consistent with solubility and dissociation thermodynamics of $\mathrm{NH}_{3}$ (gas) $/ \mathrm{NH}_{3} \cdot \mathrm{H}_{2} \mathrm{O} / \mathrm{NH}_{4}^{+}$. Surface warming is thus generally expected to reduce the non-stomatal $\mathrm{N}_{\mathrm{r}}$-sink strength, especially for $\mathrm{NH}_{3}$, with the notable exception of frozen surfaces, over which the effect of warming could be opposite. Surface-atmosphere $\mathrm{NH}_{3}$ flux measurements over moorland have in fact shown that at sub-zero temperatures the nonstomatal sink is much reduced, but also that the canopy resistance decreases as surface ice or snow melts (Flechard and 
Fowler, 1998). Warming is expected to be strongest in the mid- and especially higher latitudes (IPCC, 2013) such that vast regions in temperate to boreal climates could experience much shorter winters and significantly reduced numbers of frost days, increasing the wintertime $\mathrm{N}_{\mathrm{r}}$-sink strength. Further, because ambient $\mathrm{NH}_{3}$ concentrations should increase globally (higher ground-based emissions, and a decreased volatile aerosol $\mathrm{NH}_{4}^{+} /$total $\mathrm{NH}_{x}$ fraction), predicting the net impact on deposition fluxes is a challenge. Similarly, a reduced aerosol $\mathrm{NO}_{3}^{-} /$total $\mathrm{NO}_{y}$ fraction, and relatively higher $\mathrm{HNO}_{3}$ concentration, ought to favour overall greater $\mathrm{NO}_{y}$ dry deposition, since $\mathrm{HNO}_{3}$ deposits much faster than $\mathrm{NH}_{4} \mathrm{NO}_{3}$ aerosol (Nemitz et al., 2009; Fowler et al., 2009).

\subsubsection{Soil surface exchange}

Soils and surface leaf litter are both sinks and sources of $\mathrm{N}_{\mathrm{r}}$. The expected impacts of global change on the soil-level source strength for $\mathrm{NH}_{3}, \mathrm{NO}$ and $\mathrm{N}_{2} \mathrm{O}$ are described in detail elsewhere in this review (Sect. 4.1.1) and, in the case of NO, have been reviewed by Pilegaard (2013) and by Ludwig et al. (2001). For agricultural soils the changes are essentially controlled by agricultural management and cropping practices (especially fertilizer inputs: form, quantity, technique and timing of application), and by changes in climate that affect soil temperature and moisture, impacting on the turnover of soil organic matter (heterotrophic respiration), fertilizer infiltration, $\mathrm{NH}_{3}$ volatilization and the rates of nitrification and denitrification (Butterbach-Bahl and Dannenmann, 2011; Sutton et al., 2013b; Flechard et al., 2013). On the other hand, the $\mathrm{N}_{\mathrm{r}}$-sink strength of soils and litter surfaces is governed by the same processes - and should be similarly impacted by changes in meteorological, physical and chemical drivers - as the canopy non-stomatal sink (see above). One essential difference, though, is that soil and decaying plant material in the litter layer are much more buffered media than is leaf surface wetness such that smaller shifts in $\mathrm{pH}$ may be expected in response to the same atmospheric drivers. However, soil acidification may result from increased agricultural intensification in the 21 st century, from increased $\mathrm{N}$ deposition onto semi-natural systems, and possibly from global hydrological changes impacting on soil oxygen availability and denitrification.

\subsubsection{Chemical interactions during the exchange process}

Global change may also impact air column chemical processing within and just above vegetation canopies, creating vertical flux divergence and altering the $\mathrm{N}_{\mathrm{r}}$-sink (or source) strength. Here, for $\mathrm{N}$, the main chemical interactions are those between $\mathrm{NO}, \mathrm{O}_{3}$ and $\mathrm{NO}_{2}$ as well as the gas / aerosol partitioning involving volatile ammonium salts, primarily $\mathrm{NH}_{4} \mathrm{NO}_{3}$ and to a much lesser extent $\mathrm{NH}_{4} \mathrm{Cl}$.
Increasing global tropospheric $\mathrm{O}_{3}$ concentrations (Sitch et al., 2007) should raise the within-canopy oxidation capacity for soil-emitted NO, thereby transforming more soil NO into $\mathrm{NO}_{2}$, which can be at least partially recaptured by the overlying canopy, thus reducing total $\mathrm{NO}_{x}$ emission (or increasing net $\mathrm{NO}_{x}$ deposition) (Duyzer et al., 2004). Near and in-canopy chemistry are driven by the sharp gradients in concentrations and meteorological drivers near the ground. Thus they represent subgrid process for typical chemical transport models, where the bottom layer in which chemistry is calculated typically averages over tens of metres. Most models apply empirical formulations of the in-canopy chemical conversion and subsequent canopy reduction of the NO emission (Yienger and Levy II, 1995) that do not mechanistically respond to changes in vegetation and chemical climate. Applying a subgrid model within a chemistry-climate model to analyse the impacts of land cover and land-use changes on atmospheric chemistry at the global scale by 2050, Ganzeveld et al. (2010) calculated that changes in atmosphere-biosphere fluxes of $\mathrm{NO}_{x}$ would be small, pointing to compensating effects: although global soil $\mathrm{NO}$ emissions were expected to increase by $\sim 1.2 \mathrm{Tg} \mathrm{N} \mathrm{yr}^{-1}(+9 \%)$, decreases in soil NO emissions in deforested regions in Africa and elsewhere would be offset by a larger canopy release of $\mathrm{NO}_{x}$ caused by reduced foliage $\mathrm{NO}_{2}$ uptake. More studies of this type are needed provide a more robust basis for prediction.

Recent advances in instrumentation to measure surfaceatmosphere exchange fluxes of individual aerosol chemical components with micrometeorological techniques have led to the revelation that while effective deposition rates of sulfate are of the magnitude predicted by mechanistic aerosol deposition models $\left(<2 \mathrm{~mm} \mathrm{~s}^{-1}\right.$ for short vegetation and 1 to $10 \mathrm{~mm} \mathrm{~s}^{-1}$ to forest), measured deposition rates of $\mathrm{NO}_{3}^{-}$often reach daytime values in excess of $50 \mathrm{~mm} \mathrm{~s}^{-1}$ (Thomas, 2007; Wolff et al., 2007, 2011; Ryder, 2010). This observation is due to the fact that some of the aerosol $\mathrm{NH}_{4} \mathrm{NO}_{3}$ that passes the measurement height dissociates into $\mathrm{NH}_{3}$ and $\mathrm{HNO}_{3}$ before interacting with the surface and therefore deposits at an apparent deposition rate that reflects gas-phase deposition rather than physical interaction of particles with vegetation. The sublimation of $\mathrm{NH}_{4} \mathrm{NO}_{3}$ is driven by the depletion of $\mathrm{NH}_{3}$ and $\mathrm{HNO}_{3}$ near and in canopies, due to their dry deposition, coupled with an increase in temperature which typically peaks at the top of the canopy during daytime.

The impact of near-surface column chemistry on the exchange flux actually depends (i) on the gradients in drivers of disequilibrium (relative mixing ratios of $\mathrm{N}_{\mathrm{r}}$ species; gradients in temperature and relative humidity) and (ii) on the comparative timescales of chemical reactions and turbulent transfer to/from the surface (Nemitz et al., 2000). Global warming will shift the $\mathrm{NH}_{4}-\mathrm{HNO}_{3}-\mathrm{NH}_{4} \mathrm{NO}_{3}$ equilibrium further towards the gas phase, which will reduce the con- 
centrations of $\mathrm{NH}_{4} \mathrm{NO}_{3}$. However, as discussed above and in Sect. 4.1.1, $\mathrm{NH}_{3}$ emissions are likely to increase. $\mathrm{NO}_{x}$ emissions might well decrease, but the oxidation capacity of the atmosphere that governs the conversion of $\mathrm{NO}_{x}$ to $\mathrm{HNO}_{3}$ is more likely to increase and the change in absolute $\mathrm{NH}_{4} \mathrm{NO}_{3}$ concentrations is therefore difficult to predict accurately.

The contribution of $\mathrm{NH}_{4} \mathrm{NO}_{3}$ to European total aerosol concentration is demonstrated in Fig. 9, which summarizes campaign-based measurements of submicron aerosol composition across a coordinated network. During the colder seasons in particular, $\mathrm{NH}_{4} \mathrm{NO}_{3}$ was the single largest contributor to $\mathrm{PM}_{1}$ in north-west Europe, often exceeding the importance of organic aerosol and sulfates. Exceptions were sites on Crete (higher temperature), in Finland (few local emissions) and at high-elevation sites (long transport time, no local emissions). Even at fairly remote sites such as the Scottish EMEP Supersite Auchencorth Moss, $\mathrm{NH}_{4} \mathrm{NO}_{3}$ often accounts for the bulk of the $\mathrm{PM}_{10}$ aerosol mass during pollution events (Fig. 10). Thus, the effect of climate change on the evolution of $\mathrm{NH}_{4} \mathrm{NO}_{3}$ has important consequences for exceedances of PM air quality objectives and for the climate system.

The impact of climate change on the interaction between aerosol volatility and surface exchange is less closely linked to changes in absolute temperature and humidity (these govern the overall atmospheric burden), but to changes in nearsurface gradients in temperature, humidity and gas-phase concentrations. Increased solar radiation and reduction in evapotranspiration as a result of decreased stomatal conductance (see above) is likely to increase sensible heat fluxes and associated temperature gradients.

For the $\mathrm{NH}_{3} / \mathrm{HNO}_{3} / \mathrm{NH}_{4} \mathrm{NO}_{3}$ and $\mathrm{NH}_{3} / \mathrm{HCl} / \mathrm{NH}_{4} \mathrm{Cl}$ gas-aerosol equilibria, a surface warming and a lowering of relative humidity in a future climate would favour the faster depositing gas phase $\left(\mathrm{NH}_{3}, \mathrm{HNO}_{3}\right)$ over the slower depositing $\mathrm{NH}_{4}^{+}$and $\mathrm{NO}_{3}^{-}$aerosol. In addition, reduced $\mathrm{NO}_{x}$ emissions by 2100 (van Vuuren et al., 2011a) may result in lower $\mathrm{HNO}_{3}$ concentrations and thus reduce the secondary inorganic aerosol sink for $\mathrm{NH}_{3}$. The impact of these processes on the atmospheric lifetimes and travel distances for $\mathrm{NH}_{3}$ and $\mathrm{N}_{\mathrm{r}}$ in general, however, must be set against the expected (temperature-induced) increase in both non-stomatal resistance and in stomatal compensation point for $\mathrm{NH}_{3}$, which would have opposite effects.

\subsection{Regional and global projections for nitrogen deposition}

Future trends in total (wet and dry) atmospheric $\mathrm{N}_{\mathrm{r}}$ deposition have been simulated on the basis of CTM runs forced by climate and emission scenarios (Lamarque et al., 2005, 2013; Engardt and Langner, 2013; Simpson et al., 2014). At the regional scale, European climate-chemistry-deposition studies suggest that with current emission projections the main driver of future $\mathrm{N}_{\mathrm{r}}$ deposition changes is the specified fu-

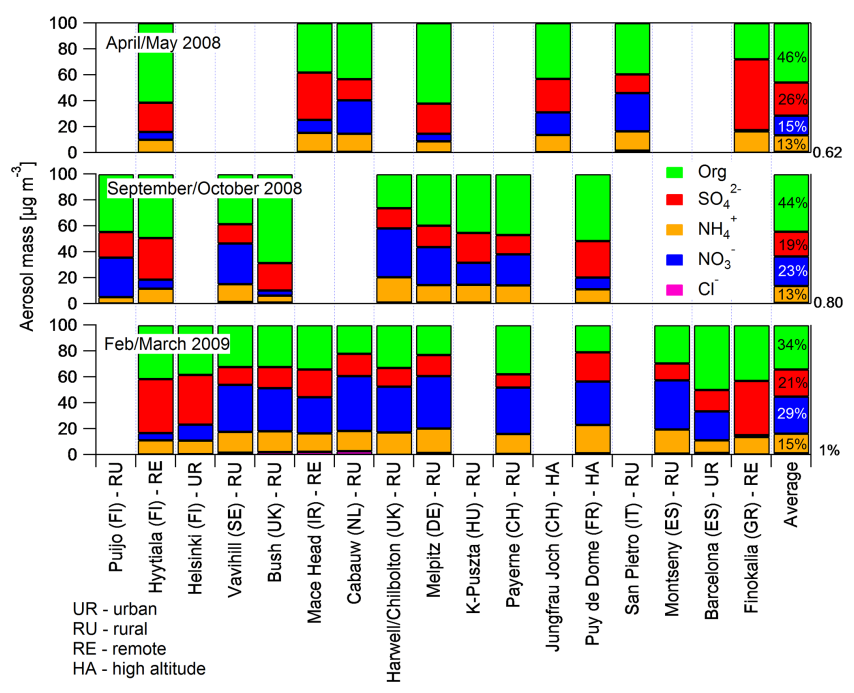

Figure 9. Relative (non-refractory) submicron aerosol composition measured with an aerosol mass spectrometer (AMS) network during three pan-European EMEP/EUCAARI campaigns. The sites are arranged from north to south.

ture emission change (Engardt and Langner, 2013; Simpson et al., 2014). These two studies both found significant reductions in oxidized $\mathrm{N}$ concentrations and deposition over Europe, and much smaller changes (both increases and decreases) in reduced $\mathrm{N}$ deposition, with climatic changes in having only moderate impact on total deposition. These two studies also demonstrated that the lack of sulfur and oxidized $\mathrm{N}$ in the future atmosphere would result in a much larger fraction of $\mathrm{NH}_{x}$ being present in the form of gaseous $\mathrm{NH}_{3}$. Simpson et al. (2014) predicted a large increase in gaseous $\mathrm{NH}_{3}$ deposition in most of Europe, but with large corresponding decreases in aerosol $\mathrm{NH}_{4}^{+}$. Although not the focus of their study, the change of $\mathrm{NH}_{4}^{+}$to $\mathrm{NH}_{3}$, while not greatly reducing the European export, would result in shorter transport distances within Europe with likely important impacts on the protection of sensitive ecosystems.

A separate recent sensitivity study has revealed that the effect of $\mathrm{NH}_{4} \mathrm{NO}_{3}$ volatilization near and in plant canopies lowers European surface concentrations of fine $\mathrm{NO}_{3}^{-}$by typically $30 \%$ at the annual average (Nemitz et al., 2014). At the same time it increases the effective $\mathrm{NO}_{3}^{-}$deposition by a factor of 4 . While some models are now able to account for some of this effect (e.g. the EMEP model; Simpson et al., 2012), it is not included in the majority of models. However, this effect has not yet been projected into the future to quantify the impacts of changes in climate.

Hemispheric $\mathrm{N}_{\mathrm{r}}$ deposition projections (Hedegaard et al., 2013) also show that the impact of emission changes dominates and is in some areas (e.g. over Europe) up to an order of magnitude higher than the signal from climate change. Nonetheless, trends in total nitrogen $\left(\mathrm{NH}_{x}+\mathrm{NO}_{y}\right)$ deposition in parts of the Arctic and at low latitudes are domi- 


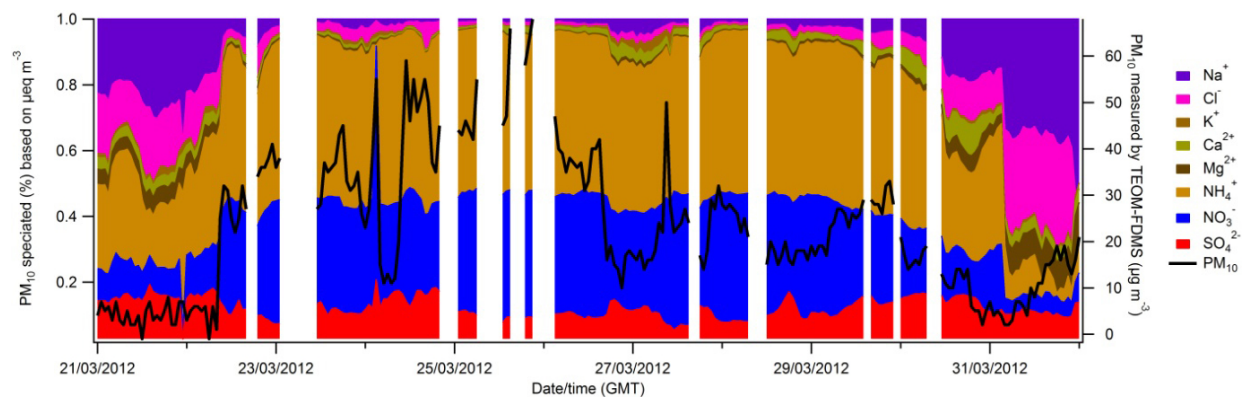

Figure 10. Relative $\mathrm{PM}_{10}$ water-soluble aerosol composition during an example pollution event observed at a rural Scottish EMEP site (Auchencorth Moss).

nated by climatic impacts. At the global scale, Lamarque et al. (2013) simulated large regional increases in $\mathrm{N}_{\mathrm{r}}$ deposition in Latin America, Africa and parts of Asia (under some of the scenarios considered) by 2100. Increases in South Asia were predicted to be especially large and were seen in all scenarios, with 2100 values more than double those of 2000 in some scenarios. Region-averaged values under scenarios RCP2.6 and RCP8.5 were typically $\sim 30-50 \%$ larger in 2100 than the current values in any region globally.

Most of these studies to date have not accounted for the full range of global change impacts on surface exchange processes. Surface exchange in most chemistry transport models (CTMs) is generally much simplified in dry deposition (downward-only) modules (Flechard et al., 2011) that cannot respond mechanistically to changes in the physical, chemical and biological drivers of stomatal, non-stomatal and soil sources or sinks. For example, multiplicative algorithms widely used to simulate $G_{\mathrm{s}}$ (Jarvis, 1976) are still the norm in these models, while photosynthesis-based approaches (e.g. Anav et al., 2012) would be needed to quantify the future impacts of rising $\mathrm{CO}_{2}$ and $\mathrm{O}_{3}$ on $G_{\mathrm{s}}$ and stomatal pollutant uptake (or release). Similarly, surface chemical interactions and their impact on non-stomatal sinks are not accounted for in CTMs. Indeed, Simpson et al. (2014) noted that modelling for especially $\mathrm{NH}_{x}$ components is limited by many factors, including process uncertainties (Massad et al., 2010a; Flechard et al., 2013), problems of subgrid heterogeneity (e.g. Loubet et al., 2001; 2009), bi-directional exchange (Wichink Kruit et al., 2012; Bash et al., 2013), and lack of necessary and accurate input data. As one example, it may be argued that such models do not account for a likely increase in the overall (stomatal and non-stomatal) surface resistance to $\mathrm{NH}_{3}$ deposition, some of which may be attributed to feedbacks: higher $\mathrm{NH}_{3}$ exposure leads to more alkaline surfaces and higher plant $\mathrm{N}$ uptake and a higher $\mathrm{NH}_{3}$ compensation point, with deposition a self-limiting process. Improved models which incorporate both better process descriptions and better input data are clearly needed to improve confidence in predictions of future $\mathrm{N}$ deposition.

Two further examples of impacts of climate change can be given, both through new sources (or forcing) of emissions: the possibility of new shipping routes in the Arctic regions and temperature-induced changes in ammonia emission factors. With regard to shipping, the rapid retreat of the Arctic Ocean has been one of the most dramatic features of recent decades (Comiso, 2012; Corbett et al., 2010). According to Corbett et al. (2010), $\mathrm{NO}_{x}$ emissions from Arctic shipping in high-growth scenarios will increase by a factor of $\sim 4$ by 2050 compared to 2004, or almost a factor of $\sim 14$ if high global shipping routes are diverted into Arctic areas. The impacts of these changes on the phyto-toxic ozone dose (POD) and $\mathrm{N}$ deposition have been explored on the regional scale using the EMEP MSC-W model (Simpson et al., 2012) by Tuovinen et al. (2013). As illustrated in Fig. 11, the impact of shipping emissions is concentrated along the Norwegian coast. Although the changes are not large, e.g. $50 \mathrm{mg}(\mathrm{N}) \mathrm{m}^{-2}$, these values are comparable to base-case deposition amounts and are likely to be important for the sensitive ecosystems in Arctic Europe. These aspects, and also the results found for POD, are discussed further in Tuovinen et al. (2013).

Simpson et al. (2014) made a first estimate of the impact of such $\mathrm{NH}_{3}$ emission increases over Europe for year 2050 simulations. They explored the impact of both 20 and $30 \%$ increases in $\mathrm{NH}_{3}$ and calculated the exceedance of critical levels (CL) for N. Comparison of these runs against the CL data (Fig. 12) shows that even a $30 \%$ increase in $\mathrm{NH}_{3}$ will not bring exceedances back to 2000 s levels, but such climateinduced increases cause CL exceedances that are substantially larger than those of the standard 2050 emission scenario. Policy studies in Europe and elsewhere have been unaware of this hidden potential for increases in $\mathrm{NH}_{3}$ emissions. As noted by Sutton et al. (2013b), the approaches used to calculate and report $\mathrm{NH}_{3}$ emissions for both CTM modelling and policy assessments need complete revision to cope this new paradigm. 


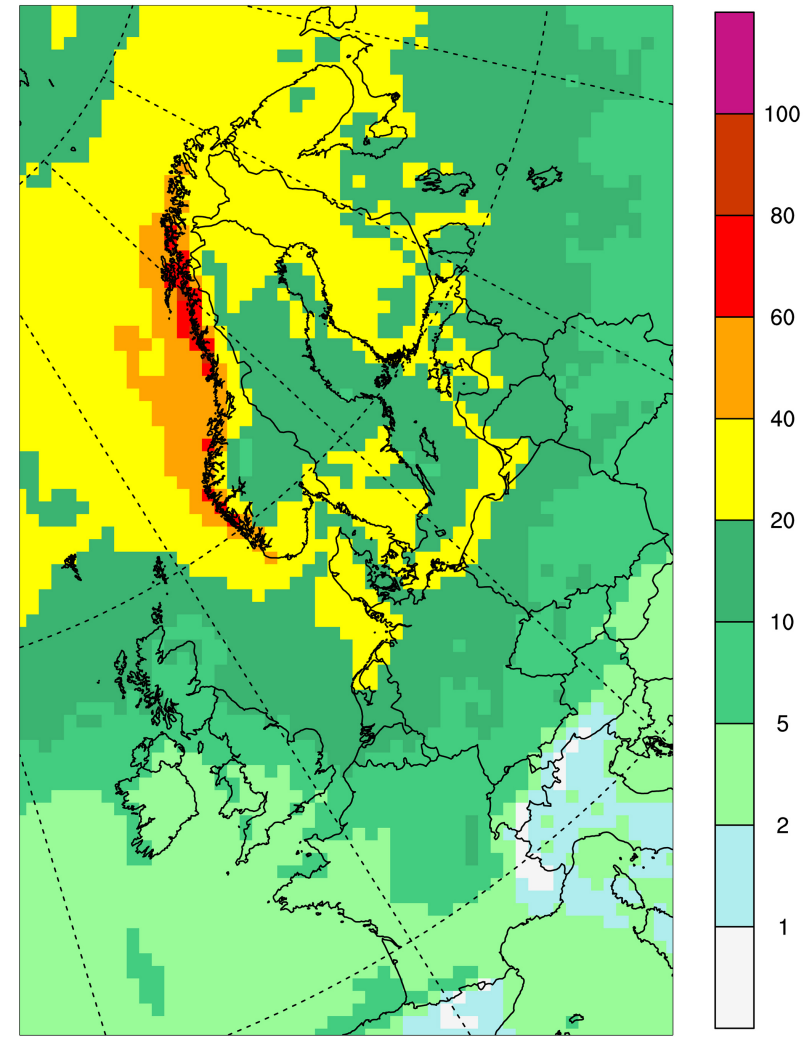

Figure 11. Increases in total $\mathrm{N}_{\mathrm{r}}$ deposition $\left(\mathrm{mg} \mathrm{m}^{-2}\right)$ due to increased Arctic shipping emissions, including diversion routes in 2030. Results are relative to a 2030 base case. Calculations from EMEP MSC-W model, redrawn from Tuovinen et al. (2013).

\section{The effects of climate and land-use changes on the wet removal of nitrogen compounds from the atmosphere}

The removal of $\mathrm{N}$ compounds from the atmosphere and their deposition to land surface by precipitation is known as "wet deposition". Future climate change will cause changes in annual precipitation with some areas of the world being subject to increases in precipitation and others to decreases. Kjellstrom et al. (2011) used an ensemble of 16 regional climate models to show that in the 21st century the precipitation in northern Europe will increase and in the south of Europe, especially the Mediterranean area, it will decrease, with a zone in between where the change is uncertain. Changes in wet deposition of $\mathrm{N}$ will be driven mainly by changes in precipitation. However the degree of increase or decrease in wet deposition is expected to be smaller than changes to precipitation. The reason for this is that the supply of particulate matter in the atmosphere which can be wet deposited is itself controlled by precipitation. Historically, drier years have been associated with higher levels of $\mathrm{NH}_{4}^{+}$and $\mathrm{NO}_{3}^{-}$particulate concentrations in air. Therefore decreases in deposition due to reduced precipitation are expected to be partially off-

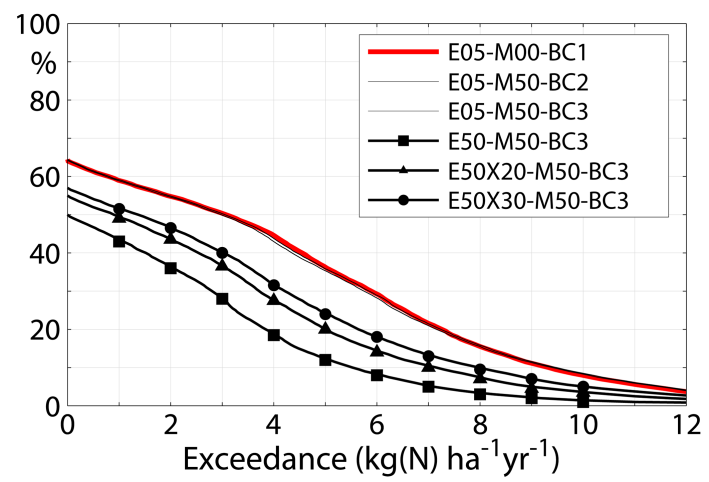

Figure 12. Frequency distribution of exceedances of the critical levels for eutrophying nitrogen in Europe (EU28+). The red line (E05M00-BC1) represents a year 2000 base case and the E50-M50-BC3 scenario represents year 2050 with current emission estimates. The E50X20 and E50X30 scenarios illustrate calculations with 20 and $30 \%$ extra $\mathrm{NH}_{3}$ emission due to climate-induced evaporation. See Simpson et al. (2014) for more details.

set by higher concentrations of $\mathrm{NH}_{4}^{+}$and $\mathrm{NO}_{3}^{-}$in precipitation.

Certain atmospheric chemical transformations have reaction rates which depend on meteorology including temperature, humidity and the presence of cloud water. A particular example of this is the equilibrium reaction between ammonia gas and nitric acid vapour to form ammonium nitrate aerosol. The dissociation constant of ammonium nitrate is a strong function of temperature and varies by 2 orders of magnitude for typical ambient conditions (Seinfield and Pandis, 1998). Higher temperatures result in a shift towards the gas phase resulting in lower concentrations of ammonium nitrate, a pollutant which is associated with long-range transport and contributes to $\mathrm{N}$ deposition through wet deposition. Changes in general circulation of air will also result in different patterns in the long-range transport of $\mathrm{N}$ compounds and the areas in which $\mathrm{N}$ is wet deposited. Studies of the long-range transport of particulate matter show that the natural inter-annual variation in circulation has a strong influence on $\mathrm{N}$-aerosol concentrations (Vieno et al., 2014). Kryza et al. (2012) found that inter-annual variation in annual precipitation could account for changes of $17 \%$ and wind direction variation for $14 \%$ in total annual $\mathrm{N}$ deposition for two European countries. Climate change may therefore lead to a re-balancing in the contributions to $\mathrm{N}$ deposition of long-range transport and local sources as well as the relative contributions of dry and wet deposition.

An additional wet deposition mechanism by which $\mathrm{N}$ can be transferred to the surface is direct cloud droplet deposition. Most types of cloud form in the middle atmosphere and do not come into direct contact with the land surface. However, in mid-latitude regions the formation of orographic clouds in hill areas is a common occurrence due to the forced ascent and condensation of humid air. Such clouds are fre- 
quently short lived and the cloud droplets do not grow large enough to form into rain drops. However, where orographic cloud does come into contact with surface vegetation, the cloud water can be deposited to the surface by direct deposition driven by air turbulence (Fowler et al., 1990). The efficiency of this mechanism depends critically on vegetation type. In grassland areas cloud deposition is generally a much less efficient mechanism for $\mathrm{N}$ deposition than wet deposition by precipitation. However in regions of forested hills, cloud deposition can be the dominant process for the input of nitrogen to sensitive upland ecosystems (Błaś et al., 2008). The impact of future climate change is expected to result in a shift in climatic zones and could cause the migration of forests to higher-altitude areas which were previously above the tree line. The consequence of this would be large increases in inputs of nitrogen due to the effect of cloud deposition.

\section{Effects of climate and land-use changes on $\mathrm{C}-\mathrm{N}$ responses in terrestrial ecosystems}

The close linkage between the terrestrial $\mathrm{C}$ and $\mathrm{N}$ cycles implies that perturbations of the $\mathrm{C}$ cycle, such as the anthropogenic increase in atmospheric $\mathrm{CO}_{2}$ (and ensuing changes in plant production), man-made climate change (affecting the turnover rates of terrestrial C), and anthropogenic landuse change, invariably have repercussions on the terrestrial $\mathrm{N}$ cycle (Zaehle, 2013). The level of understanding of these repercussions is generally low, owing to the lack of globally representative empirical studies and sufficiently tested global models (Zaehle and Dalmonech, 2011).

Observational evidence from ecosystem-scale $\mathrm{CO}_{2}$ manipulation experiments consistently shows that the magnitude and persistence of $\mathrm{CO}_{2}$ fertilization strongly depend on the ability of the vegetation to increase its $\mathrm{N}$ acquisition (Finzi et al., 2007; Palmroth et al., 2006; Norby et al., 2010; Hungate et al., 2013). The sustained increase of vegetation production observed at some experimental sites was associated with increased root exudation and soil organic matter turnover, effectively redistributing $\mathrm{N}$ from soils to vegetation (Drake et al., 2011; Hofmockel et al., 2011). Other factors such as increases in $\mathrm{N}$ inputs from fixation generally played only a small role in forest ecosystems (Norby et al., 2010; Hofmockel et al., 2007). There is mixed evidence concerning the response of ecosystem $\mathrm{N}$ losses to elevated $\mathrm{CO}_{2}$. The response of gaseous $\mathrm{N}$ losses (e.g. as $\mathrm{N}_{2} \mathrm{O}$ ) to elevated $\mathrm{CO}_{2}$ depends on the response of ecosystem $\mathrm{N}$ turnover under elevated $\mathrm{CO}_{2}$ and generally leads to an increase in $\mathrm{N}_{2} \mathrm{O}$ emissions in ecosystems where $\mathrm{N}$ availability does not strongly limit plant growth (van Groenigen et al., 2011; ButterbachBahl and Dannenmenn, 2011).

In agreement with the experimental evidence, global modelling studies generally show a strong attenuating effect of the $\mathrm{CO}_{2}$ fertilization on plant growth and land $\mathrm{C}$ storage due to reduced $\mathrm{N}_{\mathrm{r}}$ availability (Sokolov et al., 2008; Thornton et al., 2009). Future projections of $\mathrm{N}$-cycle models that accounted for varying terrestrial $\mathrm{N}$ sources and losses (XuRi and Prentice, 2008; Zaehle et al., 2010a) showed a wide range of responses of the terrestrial $\mathrm{N}$ cycle to increasing elevated $\mathrm{CO}_{2}$ (Fig. 13). This is due to diverging representation of important $\mathrm{N}$-cycle processes, in particular those controlling in- and outflows of $\mathrm{N}$ from the ecosystem and the coupling of the $\mathrm{C}$ and $\mathrm{N}$ stoichiometry in plants and soils (Zaehle and Dalmonech, 2011; Zaehle et al., 2014). The increase in terrestrial $\mathrm{N}$ by up to $11 \mathrm{Pg} \mathrm{N}(+10 \%)$ during the period 1860-2100 in the LPX model was mostly determined by increasing biological $\mathrm{N}$ fixation under elevated $\mathrm{CO}_{2}$ (Stocker et al., 2013). Over the same time period, the response of the $\mathrm{O}-\mathrm{CN}$ model was determined by an increase of the vegetation and soil $\mathrm{C}: \mathrm{N}$ ratios as well as increases in terrestrial $\mathrm{N}(3 \mathrm{Pg} \mathrm{N} ;+2.5 \%)$ due to reduced $\mathrm{N}$ losses (Zaehle et al., 2010b). The projections by the CN-TEM model (Sokolov et al., 2008), which assumes that the total terrestrial $\mathrm{N}$ store is time-invariant, suggested an increase in terrestrial $\mathrm{C}$ between 1860 and 2100 by $\sim 250 \mathrm{Pg} \mathrm{C}$ simply due to a prescribed increase in vegetation $\mathrm{C}: \mathrm{N}$ and redistribution of $\mathrm{N}$ from soils to vegetation.

In response to increasing temperature, enhanced decomposition of soil organic matter consistently increases gross and net $\mathrm{N}$ mineralization (Bai et al., 2013; Rustad et al., 2001). Increased mineralization is generally, but not always, associated with increases in nitrification, and $\mathrm{N}_{2} \mathrm{O}$ emissions. There is ambiguous evidence as to the response of N-leaching losses, which in some cases increased and in others declined (Bai et al., 2013). Observed growth responses to warming are more diverse, partly owing to difficulties in measuring plant growth and its interannual variability (Rustad et al., 2001). In $\mathrm{N}$-limited ecosystems, increased $\mathrm{N}$ mineralization increases $\mathrm{N}$ uptake of vegetation, which causes a long-term fertilization effect in N-limited forests (Melillo et al., 2002, 2011). In consequence, despite likely $\mathrm{N}$ losses due to warming, the higher $\mathrm{C}: \mathrm{N}$ ratio in woody vegetation compared to $\mathrm{C}: \mathrm{N}$ ratio of soil organic matter causes increased ecosystem carbon storage due to the redistribution of $\mathrm{N}$ from soil to vegetation (Melillo et al., 2011).

Global models include these mechanisms and consistently suggest an attenuation of the $\mathrm{C}$ loss under higher temperatures due to $\mathrm{C}-\mathrm{N}$-cycle interactions. However, the available climate change projections vary widely in their global $\mathrm{N}$ cycle response, partly owing to differences in magnitude and regional patterns of temperature and precipitation changes (Stocker et al., 2013). In general, soil N stocks tend to decline in future projections, due to increased soil $\mathrm{N}$ mineralization and increased ecosystem $\mathrm{N}$ losses (Fig. 13). These losses range between 5 and $10 \mathrm{Pg} \mathrm{N}$ (roughly 5-10\%) between 1860 and 2100, depending on the model and scenario applied (Stocker et al., 2013; Zaehle et al., 2010a). Although regionally there are increases in vegetation $\mathrm{N}$ associated with the redistribution of $\mathrm{N}$ from soils to vegetation, the models 
project a decline in the global vegetation $\mathrm{N}$ store, partly related to declining tropical forest biomass. It is worth noting that the $\mathrm{N}$ redistribution effect due to climate warming has important implications for the carbon-cycle-climate interaction, which is generally thought to be positive, i.e. amplifying climate change (Gregory et al., 2009). In two studies which either assumed a closed $\mathrm{N}$ cycle with no losses or had small positive carbon-cycle-climate feedback, the response of vegetation growth was strong enough to turn the carbon-cycleclimate interaction into a small negative feedback (Sokolov et al., 2008; Thornton et al., 2009), whereas in another study that described $\mathrm{C}-\mathrm{N}$ interactions (Zaehle et al., 2010a), the carbon-climate interaction was reduced but remained positive.

The responses of the $\mathrm{C}$ and $\mathrm{N}$ cycles to land-use changes are diverse and depend on many details of the conversion process such that it is difficult to establish generic patterns. Converting the land-use type of an ecosystem causes a pronounced disruption of the $\mathrm{N}$ cycle, because typically the vegetation $\mathrm{N}$ (and C) and sometimes fractions of the litter layer and soil organic material are removed. This causes a phase of reduced vegetation $\mathrm{N}$ uptake and enhanced $\mathrm{N}$ losses. Forest regrowth is typically associated with an early phase of vigorous tree growth and associated high plant $\mathrm{N}$ demands, leading to a conservative $\mathrm{N}$ cycle with high $\mathrm{N}$ accumulation rates compared to pastures and croplands and consequently reduced N losses (e.g. Davidson et al., 2007). Associated with the forest-to-cropland of grassland-forest conversion are typically declines in soil organic matter stocks (Guo and Gifford, 2002). However, the intricate processes of the $\mathrm{N}$ cycle can overrule these trends under particular conditions (Kirschbaum et al., 2008). On a decadal to century timescale, afforestation and reforestation are therefore typically associated with reduced $\mathrm{N}_{2} \mathrm{O}$ emission and $\mathrm{N}$ as well as $\mathrm{C}$ accumulation, whereas the inverse is true for forest to cropland conversions (Davidson et al., 2007; Kirschbaum et al., 2013).

Not much is known about the large-scale N-cycle consequences of land-use change per se, partly owing to the simplistic representation of land use and land-use change in most global models (Brovkin et al., 2013). Global model simulations suggest (Fig. 13) that the changes in N storage will largely follow the trends in the $\mathrm{C}$ cycle (Zaehle, 2013; Stocker et al., 2013; Brovkin et al., 2013), implying that scenarios will lead to a decline in the vegetation $\mathrm{N}$ storage because of the removal of the above-ground vegetation (Fig. 13), and vice versa. Using scenarios in which widespread increases in agricultural and pasture areas occur at the expense of forests, global soil $\mathrm{C}$ stocks decline with land-use change. However, given that croplands are typically extensively fertilized, the $\mathrm{C}: \mathrm{N}$ ratio of the soil is often lower, given the higher $\mathrm{N}$ content of plant matter, such that the soil retains more $\mathrm{N}$ after conversion. The LPX model estimates this conversion effect to be of the order of $2 \mathrm{PgN}$ for the RCP2.6 and 8.5 scenarios (Stocker at al., 2013). These es- timates should be treated with due caution, given that these models do not account for a lot of the detailed processes, which affect in particular the change of soil $\mathrm{N}$ with time, such as the age-structure and age-dependent development of forests, or the effects of cropland management besides fertilizer additions.

Associated with the projected changes in the terrestrial $\mathrm{N}$ and $\mathrm{C}$ pools (Fig. 13) are large projected changes in the future net ecosystem $\mathrm{N}$ and $\mathrm{C}$ balance. Of these fluxes, the change in terrestrial $\mathrm{N}_{2} \mathrm{O}$ emission is likely the most climatically relevant factor. Figure 14 shows that projections of the effect of increasing atmospheric $\mathrm{CO}_{2}$ on the $\mathrm{N}_{2} \mathrm{O}$ emissions differ more strongly between models than alternative plausible scenarios of atmospheric $\mathrm{CO}_{2}$. This difference reflects the large impact of alternative hypotheses about the likely changes of biological $\mathrm{N}$ fixation with elevated $\mathrm{CO}_{2}$, which are large in LPX but insignificant in the $\mathrm{O}-\mathrm{CN}$ model. In $\mathrm{O}-\mathrm{CN}$, this leads to a progressively more conservative $\mathrm{N}$ cycle with reduced $\mathrm{N}$ losses, as vegetation growth and $\mathrm{N}$ sequestration increase due to $\mathrm{CO}_{2}$ fertilization. Climate change consistently increases $\mathrm{N}_{2} \mathrm{O}$ emissions from terrestrial ecosystems. However, the magnitude of this change is dependent both on the model used (with the LPX model having a higher sensitivity to climate change (Ciais et al., 2013) and the particular climate change scenario. An assessment of the effect of diverging model projections of climate change patterns for a given climate change scenario based on the LPX model revealed large uncertainty in the response of the terrestrial $\mathrm{N}_{2} \mathrm{O}$ emissions, which is nonetheless smaller than the differences across alternative climate change scenarios (Stocker et al., 2013). Land-use change per se has little influence on the terrestrial $\mathrm{N}_{2} \mathrm{O}$ emissions. However, the historical increase in $\mathrm{N}$-fertilizer use has led to a significant increase in the terrestrial N source (Zaehle et al., 2011; Stocker et al., 2013). Importantly, there is a strong interaction between the climate response of terrestrial $\mathrm{N}_{2} \mathrm{O}$ emission and $\mathrm{N}$ fertilization, as the rate of $\mathrm{N}_{2} \mathrm{O}$ production for a given addition of fertilizer increases with climate warming (Butterbach-Bahl and Dannenmann, 2011; Stocker et al., 2013).

\section{Discussion and policy implications of the responses of the nitrogen cycle to global change}

\subsection{Emissions and cycling}

The changes in fluxes of $\mathrm{N}$ within the global cycle discussed in the main sections of this paper are summarized in Fig. 15. Biological fixation of molecular nitrogen (BNF) is expected to increase during the 21 st century both in the oceans (120 to $166 \mathrm{Tg} \mathrm{Nyr}^{-1}$ ) and terrestrial environments (128 to $170 \mathrm{Tg} \mathrm{N} \mathrm{yr}^{-1}$ ) due mainly to changes in climate. Anthropogenic emissions of $\mathrm{NH}_{3}$ are projected to increase substantially, from 60 to $135 \mathrm{Tg} \mathrm{Nyr}^{-1}$. The increase has two components: (i) the effect of climate, in which higher tem- 

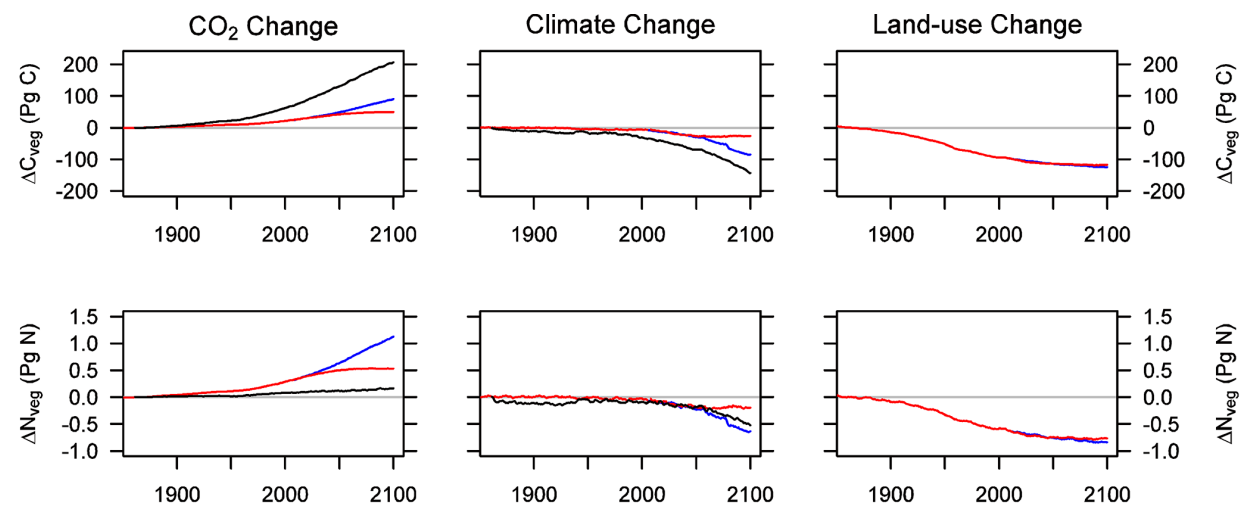

$$
\begin{aligned}
& z \\
& 0 \\
& 0 \\
& 0 \\
& 0 \\
& z \\
& y
\end{aligned}
$$
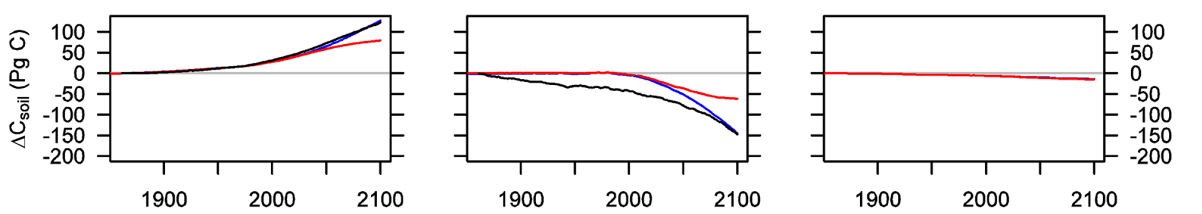

\section{0
0
$\overline{\overline{0}}$
$0^{\circ}$}
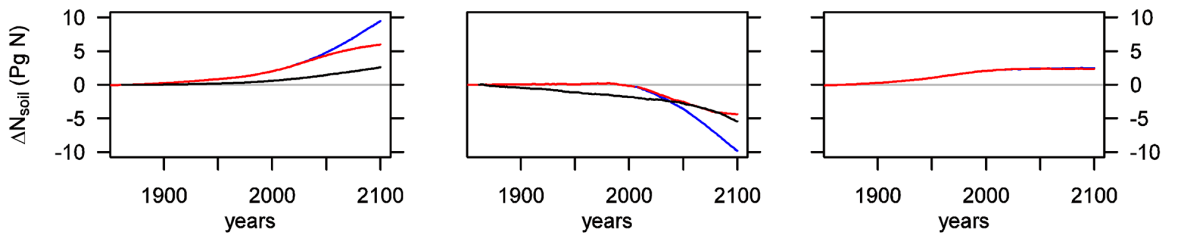

$z$
0
0
$\overline{0}$
$z$
$z$

— LPX:RCP 26

LPX: RCP 8.5 - O-CN: SRES-A2

Figure 13. Responses of the terrestrial vegetation and soil $\mathrm{C}$ and $\mathrm{N}$ pools to projected changes of the atmospheric $\mathrm{CO}_{2}$ burden, climate, and land use between 1860 and 2100, as simulated by two global terrestrial biosphere models (LPX, Stocker et al., 2013; and O-CN, Zaehle et al., 2010a). The LPX simulations are based on the climate change projections of HadGEM2-ES model using atmospheric greenhouse gas and land-use forcing for the RCP2.6 and 8.5 scenarios. The O-CN simulations have been driven by climate change projections of the IPSL-CM4 model using the atmospheric greenhouse gas forcing of the SRES-A2 scenario.
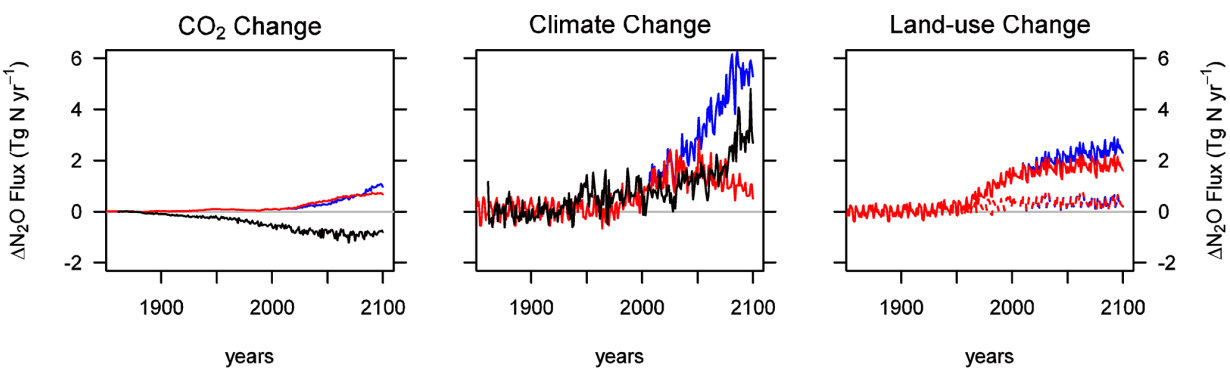

— LPX: RCP $2.6-$ LPX: RCP $8.5-$ O-CN: SRES-A2

Figure 14. Changes in terrestrial $\mathrm{N}_{2} \mathrm{O}$ emissions from pre-industrial conditions to projected changes of the atmospheric $\mathrm{CO}_{2}$ burden, climate, and land use, as simulated by the two global terrestrial biosphere models (LPX and O-CN), as in Fig. 13. Dashed lines in the land-use change panel refer to projected $\mathrm{N}_{2} \mathrm{O}$ emission without the change in fertilizer inputs associated with the RCP scenarios (Stocker et al., 2013).

perature increases terrestrial emissions and (ii) the effect of increases in $\mathrm{N}_{\mathrm{r}}$ fixed by anthropogenic activity in part due to increased demand for food, driven by increases in both global population and changes in diet (especially global meat consumption per capita). By contrast, emissions of combustion- related $\mathrm{NO}_{x}$ are projected to decline as the widespread use of control technology (catalytic converters on vehicles and SCR on industrial plant) more than compensates for increases in transport and power production. 


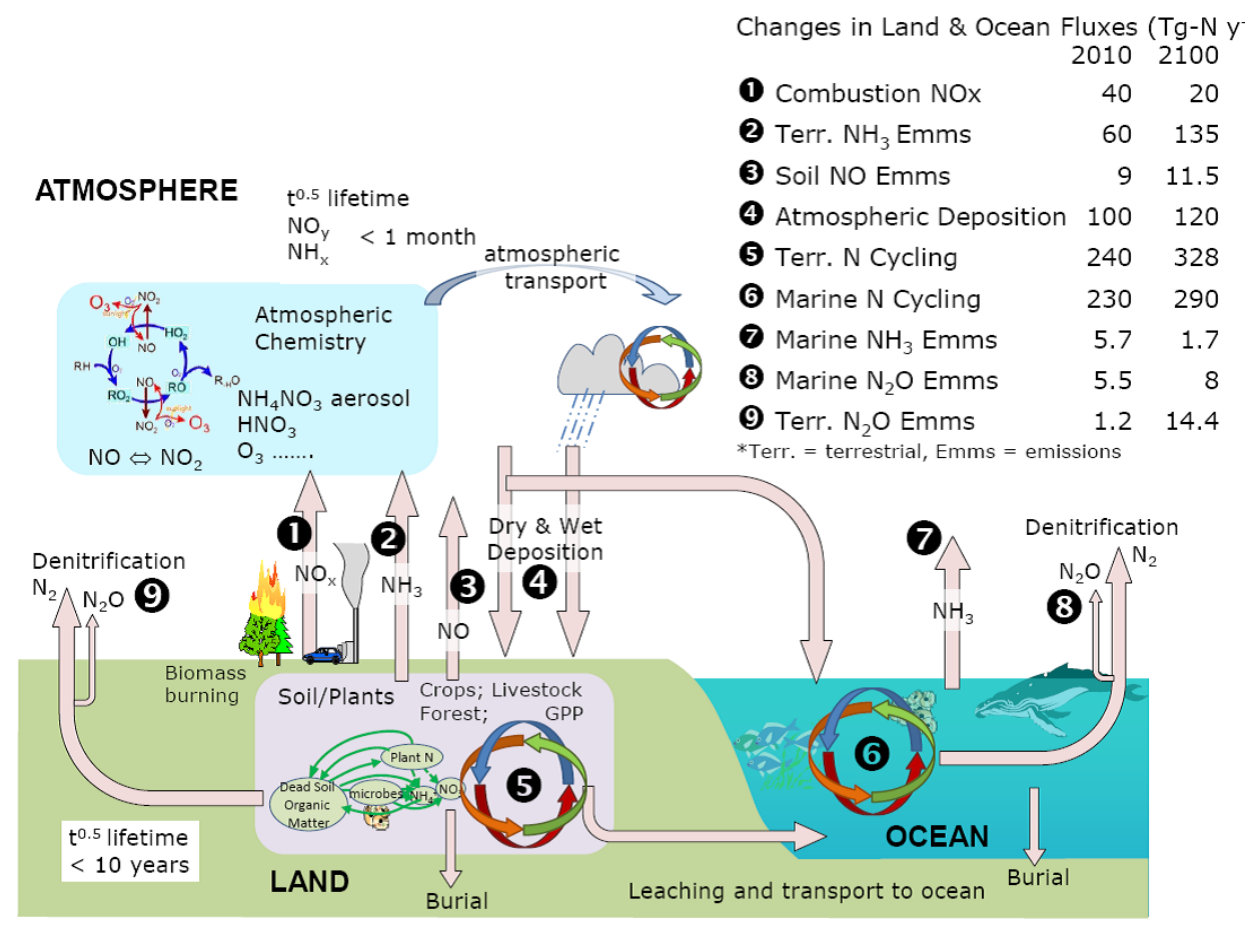

Figure 15. Changes in the major fluxes and in the terrestrial, marine and atmospheric processing of reactive nitrogen $\left(\mathrm{N}_{\mathrm{r}}\right)$ between 2010 and 2100, adapted from Fowler et al., 2013).

The changes in emissions are spatially very variable, reflecting both the current global hotspots of $\mathrm{N}_{\mathrm{r}}$ use in Europe, North American and Asia and the expected increases in South and East Asia, Africa and South America where the largest growth in $\mathrm{N}_{\mathrm{r}}$ use is expected.

Not all fluxes are projected to be larger at the end of the century, with smaller emissions of $\mathrm{NO}_{x}$ from anthropogenic sources and reduced emission of $\mathrm{NH}_{3}$ from the oceans (5.7 declining to $1.7 \mathrm{Tg} \mathrm{N} \mathrm{yr}^{-1}$ ) due to the effects of ocean acidification more than compensating for the effects of higher water temperatures.

The two large cycles of $\mathrm{N}_{\mathrm{r}}$ in terrestrial soils and in the oceans both increase substantially: 240 to $328 \mathrm{Tg} \mathrm{N} \mathrm{yr}^{-1}$ for soils and 230 to $290 \mathrm{Tg} \mathrm{N} \mathrm{yr}^{-1}$ in the oceans (Fig. 15).

\subsection{Effects of changes in atmospheric composition on long-range transport of $\mathrm{N}_{\mathbf{r}}$}

The removal of sulfur from the atmospheres over $\mathrm{Eu}-$ rope and North America has changed the aerosol composition in these regions, with the inorganic aerosol $\mathrm{N}_{\mathrm{r}}$ dominated by $\left(\mathrm{NH}_{4}\right)_{2} \mathrm{SO}_{4}$ prior to 1990 and by $\mathrm{NH}_{4} \mathrm{NO}_{3}$ in more recent years. Cool season episodes with high particulate matter (PM) concentrations occur widely in Europe in which $\mathrm{NH}_{4} \mathrm{NO}_{3}$ is a major contributor (Vieno et al., 2014). Likewise in Beijing, $\mathrm{NH}_{4} \mathrm{NO}_{3}$ is important in winter $\mathrm{PM}$ episodes, contributing on average approximately $30 \%$ of the $\mathrm{PM}_{10}$ mass (Sun et al., 2013). The change in aerosol com- position has changed the atmospheric lifetime, deposition footprint and transport distance of much of the emitted reactive nitrogen. Aerosols comprising $\left(\mathrm{NH}_{4}\right)_{2} \mathrm{SO}_{4}$ are largely non-volatile; once formed the aerosol stays in aerosol form until scavenged from the atmosphere by rain. By contrast, $\mathrm{NH}_{4} \mathrm{NO}_{3}$ is volatile, and close to terrestrial surfaces the deposition of the gaseous $\mathrm{HNO}_{3}$ and $\mathrm{NH}_{3}$ to the surface drive the sublimation of the aerosol, especially in warm daytime conditions. These effects increase the atmospheric removal rate of $\mathrm{NH}_{4} \mathrm{NO}_{3}$ relative to $\left(\mathrm{NH}_{4}\right)_{2} \mathrm{SO}_{4}$ and reduce the lifetime and travel distance of $\mathrm{N}_{\mathrm{r}}$ with time during the last 20 years in Europe and North America as the sulfur has been removed from emissions. The trends of increasing importance of $\mathrm{NO}_{3}^{-}$aerosols are projected to continue through to the end of this century, with $\mathrm{NH}_{4} \mathrm{NO}_{3}$ becoming a dominant inorganic component over many regions, despite reductions in $\mathrm{NO}_{x}$ emission due to the increased availability of $\mathrm{NH}_{3}$ (Hauglustaine et al., 2014). Overall, the changes in atmospheric composition have increased the importance of nitrogen compounds, as a fraction of the pollutant mixture present and in their role in generating effects on ecosystems, human health and climate. One aspect of the likely changes in the characteristics of $\mathrm{N}_{\mathrm{r}}$ in the environment is the likely changes in the deposition footprint of reactive nitrogen resulting from changes in climate. To date, the effects of climate change on regional patterns of deposition have been explored using regional chemistry-transport models, as described in Sect. 7. The effect on emission - and deposition footprints at the lo- 
Table 3. Societal costs of nitrogen emissions in ranges based on Brink et al. (2011). Units are EUR $\left(\mathrm{kg} \mathrm{N}_{\mathrm{r}}\right)^{-1}$.

\begin{tabular}{llllll}
\hline $\begin{array}{l}\mathrm{N}_{\mathrm{r}} \\
\text { flux }\end{array}$ & Health & $\begin{array}{l}\text { Ecosystem/ } \\
\text { coastal systems }\end{array}$ & $\begin{array}{l}\text { Crop decline } \\
\mathrm{O}_{3}\end{array}$ & Climate & Total \\
\hline $\mathrm{NO}_{x}-\mathrm{N}$ to air & $10-30$ & $2-10$ & $1-3$ & & $13-43$ \\
$\mathrm{NH}_{3}-\mathrm{N}$ to air & $1-20$ & $2-10$ & & & $3-30$ \\
$\mathrm{~N}_{\mathrm{r}}$ to water & $0-4$ & $5-50$ & & $1-15$ & $2-54$ \\
$\mathrm{~N}_{2} \mathrm{O}-\mathrm{N}$ to air & $1-3$ & & & $2-18$ \\
\hline
\end{tabular}

cal scale - has not so far been explored even though the principles have been established of substantially larger emissions of $\mathrm{NH}_{3}$ (Sutton et al., 2013b) and increased volatilization of aerosol $\mathrm{NH}_{4} \mathrm{NO}_{3}$ (Nemitz et al., 2014) close to terrestrial surfaces. These changes raise the importance of control measures for emissions of both ammonia and nitrogen oxides and the need for further modelling and field validation of the interactions between reactive nitrogen in the environment and climate.

\subsection{Costs}

Emissions of $\mathrm{N}_{\mathrm{r}}$ from farming activities to the atmosphere, soils and freshwaters are large per unit area relative to the fluxes involved in natural ecosystem BNF and are a substantial contributor to the emission and global $\mathrm{N}_{\mathrm{r}}$ deposition hotspots, damage to ecosystems and effects on human health. The processing of $\mathrm{N}_{\mathrm{r}}$ in soils and vegetation leads to a wide range of mobile gas- and solution-phase species and leaks to the wider environment. Only a small fraction (between 20 and $30 \%$ ) of the $\mathrm{N}_{\mathrm{r}}$ used in agriculture is consumed by humans in food (Sutton et al., 2013a); most is wasted either in reactive forms or transformed back to $\mathrm{N}_{2}$. Current societal costs due to these losses of $\mathrm{N}_{\mathrm{r}}$ to the environment are very large. Recent cost-benefit analyses of $\mathrm{N}_{\mathrm{r}}$ have been attempted for the Chesapeake Bay in the US (Birch et al., 2011), for Europe (Brink et al., 2011) and as a broad overview for the US (Compton et al., 2011). Table 3 shows the ranges of estimated societal costs per $\mathrm{N}_{\mathrm{r}}$ component loss and impact, based on the "willingness to pay" method for EU27 (Brink et al., 2011). Based on these costs, the most important component of the $\mathrm{N}_{\mathrm{r}}$ cycle is the emission of $\mathrm{NO}_{x}$, due to the human health impacts of both particulate matter and ozone. Sutton et al. (2011) estimated that the agricultural benefits of $\mathrm{N}_{\mathrm{r}}$ in Europe are between EUR 10 and 100 billion per year, while the total environmental costs based on the values in Table 3 is in the range EUR 20 and 150 billion per year, making the point that the costs and benefits are of a similar magnitude.

\subsection{Policies to reduce the impacts of $\mathrm{N}_{\mathrm{r}}$}

The overall mass balance for nitrogen compounds is constrained by mass conservation (what goes up must come down); thus the effect of the deposition rate by itself does not change the amount of $\mathrm{N}_{\mathrm{r}}$ deposited globally, but the transport distance of the different compounds and regional and importantly the country import-export budgets are changed by changes in chemistry and deposition of the $\mathrm{N}_{\mathrm{r}}$ forms present. Only changes to the emissions affect the total $\mathrm{N}_{\mathrm{r}}$ amount deposited.

In Europe and the US there are examples of successful policies that have led to reduced $\mathrm{NO}_{x}$ emissions, through the air quality standards for $\mathrm{O}_{3}$ and $\mathrm{NO}_{2}$ in the US and through UN-ECE $\mathrm{NO}_{x}$ and Gothenburg protocols in Europe and large combustion plant directives within the EU. Successful technologies include the three-way catalysts in vehicle exhausts and the Selective Catalytic Converter systems in industry and energy production. Emissions of $\mathrm{NO}_{x}$ declined by $40 \%$ in 2009 relative to 1990 in EU27 (EEA, 2012). Policies to reduce $\mathrm{NH}_{3}$ emission have been much less successful. For $\mathrm{NH}_{3}$, in the US there are no policies while in Europe the Gothenburg protocol (national $\mathrm{NO}_{x}$ and $\mathrm{NH}_{3}$ emission ceilings) has led to modest (14\%) reductions (EEA, 2012). There are, however, two countries that implemented substantial $\mathrm{NH}_{3}$ abatement measures and reduced emissions by $40 \%$ in Denmark and $50 \%$ in the Netherlands. Abatement technologies included low-emission housing systems, coverage of manure storage facilities and application of slurry injection technologies. Furthermore, total $\mathrm{N}$ inputs in agriculture were reduced by reducing $\mathrm{N}$ in feed and by reducing mineral fertilizer application (Erisman et al., 2005).

The general options of policies to reduce the cascade effect of $\mathrm{N}_{\mathrm{r}}$ are the following:

1. limit $\mathrm{N}_{\mathrm{r}}$ production or limit import of $\mathrm{N}$ through animal concentrates

2. increase $\mathrm{N}_{\mathrm{r}}$ use efficiency

3. more evenly distribute $\mathrm{N}$ production over the country, over the EU or the world

4. convert $\mathrm{N}_{\mathrm{r}}$ to $\mathrm{N}_{2}$ catalytically or by stimulating denitrification.

Substantial reductions in $\mathrm{N}_{\mathrm{r}}$ production by fossil fuels may be achieved by use of renewable energy such as solar, wind and water technologies. The use of biomass as an alternative energy source is not an effective strategy to reduce emissions of $\mathrm{N}_{\mathrm{r}}$ (Erisman et al., 2008). Consumer changes in diet 
and lifestyle present potentially effective measures to reduce emissions but have proved difficult to implement. Reductions in consumption and therewith production of $\mathrm{N}_{\mathrm{r}}$ intensive goods and services offer further valuable control measures that have not been used to date.

Increasing nitrogen use efficiency (NUE) in agricultural systems and by closing nutrient cycles on different scales represents an important guiding principle which has the capacity to deliver both reductions in emission of $\mathrm{N}_{\mathrm{r}}$ to the environment and reduced costs in food production. Furthermore as only between 20 and $30 \%$ of the nitrogen used in agriculture is consumed by humans, the potential gains in NUE are considerable (MacLeod et al., 2010). The concentration and specialization of intensive agriculture in certain regions creates $\mathrm{N}_{\mathrm{r}}$ hotspots, such as in the Netherlands and the North China Plain (Chen et al., 2014; Shen et al., 2013). In these regions emissions of $\mathrm{N}_{\mathrm{r}}$ are visible not just in local measurements but also increasingly from space using satellite remote sensing (Van Damme et al., 2014). If these agricultural activities were distributed more evenly across the globe, and livestock production were located in places where the nutrients are readily available, the $\mathrm{N}_{\mathrm{r}}$ losses would be much reduced.

Finally whenever the above options do not prove effective, $\mathrm{N}_{\mathrm{r}}$ should be converted back into $\mathrm{N}_{2}$ by denitrification, to remove $\mathrm{N}_{\mathrm{r}}$ from the cascade. Examples of such options include the use of wetlands and wastewater treatment plants.

The most effective measures that were selected based on an evaluation of successful policies in the Netherlands were the following:

- increasing nitrogen use efficiency in agriculture

- closing nutrient cycles at different levels

- influencing consumer behaviour towards reduced meat consumption

- using technology to reduce emissions from different compartments

- using spatial planning as a tool to optimize production and environmental protection.

In intensive agricultural areas, increasing NUE can be very effective in the short term, whereas in areas with low $\mathrm{N}$ inputs closing the nutrient balances is more effective.

Policy instruments are needed to increase NUE. Sutton et al. (2013b) proposed increases in NUE of $20 \%$ in agricultural $\mathrm{N}_{\mathrm{r}}$-excess areas of the world to reduce the effects of $\mathrm{N}_{\mathrm{r}}$ on human health, climate and ecosystems. This would represent a first step to work towards a global policy of nutrient management. However, agricultural subsidies and trade restrictions differ greatly between countries and regions. Such realities distort trade and complicate the introduction of measures designed to promote environmental protection through increased nitrogen use efficiency.
Acknowledgements. The authors gratefully acknowledge the support from the following EU projects for the preparation of this paper: ACCENT+, PEGASOS Legume Futures, ECLAIRE, the UK Defra, and the UK Natural Environment Research Council (NERC).

Edited by: U. Pöschl

\section{References}

Abalos, D., Sanchez-Martin, L., Garcia-Torres, L., van Groenigen, J. W., and Vallejo, A.: Management of irrigation frequency and nitrogen fertilization to mitigate GHG and NO emissions from drip-fertigated crops, Sci. Total Environ., 490, 880-888, doi:10.1016/j.scitotenv.2014.05.065, 2014.

Abdalla, M., Osborne, B., Lanigan, G., Forristal, D., Williams, M., Smith, P., and Jones, M. N.: Conservation tillage systems: a review of its consequences for greenhouse gas emissions, Soil Use Manage., 29, 199-209, doi:10.1111/sum.12030, 2013.

Ainsworth, E. A. and Rogers, A.: The response of photosynthesis and stomatal conductance to rising $\left[\mathrm{CO}_{2}\right]$ : mechanisms and environmental interactions, Plant Cell Environ., 30, 258-270, doi:10.1111/j.1365-3040.2007.01641.x, 2007.

Altieri, K. E., Turpin, B. J., and Seitzinger, S. P.: Composition of dissolved organic nitrogen in continental precipitation investigated by ultra-high resolution FT-ICR mass spectrometry, Environ. Sci. Technol., 43, 6950-6955, doi:10.1021/es9007849, 2009.

Altieri, K. E., Hastings, M. G., Peters, A. J., and Sigman, D. M.: Molecular characterization of water soluble organic nitrogen in marine rainwater by ultra-high resolution electrospray ionization mass spectrometry, Atmos. Chem. Phys., 12, 3557-3571, doi:10.5194/acp-12-3557-2012, 2012.

Anav, A., Menut, L., Khvorostyanov, D., and Viovy, N.: A comparison of two canopy conductance parameterizations to quantify the interactions between surface ozone and vegetation over Europe, J. Geophys. Res.-Biogeo., 117, G03027, doi:10.1029/2012JG001976, 2012.

Attard, E., Recous, S., Chabbi, A., De Berranger, C., Guillaumaud, N., Labreuche, J., Philippot, L., Schmid, B., and Le Roux, X.: Soil environmental conditions rather than denitrifier abundance and diversity drive potential denitrification after changes in land uses, Global Change Biol., 17, 1975-1989, doi:10.1111/j.13652486.2010.02340.x, 2011.

Baggs, E. M.: A review of stable isotope techniques for $\mathrm{N}_{2} \mathrm{O}$ source partitioning in soils: recent progress, remaining challenges and future considerations, Rapid Commun. Mass Sp., 22, 16641672, doi:10.1002/rcm.3456, 2008.

Bai, E., Li, S., Xu, W., Li, W., Dai, W., and Jiang, P.: A meta-analysis of experimental warming effects on terrestrial nitrogen pools and dynamics, New Phytol., 199, 441-451, doi:10.1111/nph.12252, 2013.

Baldocchi, D. D., Hicks, B. B., and Camara, P.: A canopy stomatal resistance model for gaseous deposition to vegetated surfaces, Atmos. Environ., 21, 91-101, doi:10.1016/00046981(87)90274-5, 1987.

Barbaro, E., Zangrando, R., Moret, I., Barbante, C., Cescon, P., and Gambaro, A.: Free amino acids in atmospheric particu- 
late matter of Venice, Italy, Atmos. Environ., 45, 5050-5057, doi:10.1016/j.atmosenv.2011.01.068, 2011.

Barcelos e Ramos, J., Biswas, H., Schulz, K. G., LaRoche, J., and Riebesell, U.: Effect of rising atmospheric carbon dioxide on the marine nitrogen fixer Trichodesmium, Global Biogeochem. Cy., 21, GB2028, doi:10.1029/2006GB002898, 2007.

Barton, L., McLay, C. D. A., Schipper, L. A., and Smith C. T., Annual denitrification rates in agricultural and forest soils: a review, Aust. J. Soil Res., 37, 1073-1093, doi:10.1071/SR99009, 1999.

Bash, J. O., Cooter, E. J., Dennis, R. L., Walker, J. T., and Pleim, J. E.: Evaluation of a regional air-quality model with bidirectional $\mathrm{NH}_{3}$ exchange coupled to an agroecosystem model, Biogeosciences, 10, 1635-1645, doi:10.5194/bg-10-1635-2013, 2013.

Bates, T. S., Cline, J. D., Gammon, R. H., and Kelly-Hansen, S. R.: Regional and seasonal variations in the flux of oceanic dimethylsulfide to the atmosphere. J. Geophys. Res., 92, 2930-2938, doi:10.1029/JC092iC03p02930, 1987.

Bell, T. G., Johnson, M. T., Jickells, T. D., and Liss, P. S.: Ammonia/ammonium dissociation coefficient in seawater: A significant numerical correction, Environ. Chem., 4, 183-186, doi:10.1071/ENO7032, 2007.

Bencs, L., Krata, A., Horemans, B., Buczyńska, A. J., Dirtu, A. C., Godoi, A. F. L., Godoi, R. H. M., Potgieter-Vermaak, S., and Van Grieken, R.: Atmospheric nitrogen fluxes at the Belgian coast: 2004-2006. Atmos. Environ., 43, 3786-3798, doi:10.1016/j.atmosenv.2009.04.002, 2009.

Berman-Frank, I., Cullen, J. T., Shaked, Y., Sherrell, R. M., and Falkowski, P. G.: Iron availability, cellular iron quotas, and nitrogen fixation in Trichodesmium, Limnol. Oceanogr., 46, 1249 1260, doi:10.4319/lo.2001.46.6.1249, 2001.

Birch, M. B. L., Gramig, B. M., Moomaw, W. R., Doering III, O. C., and Reeling, C. J.: Why metrics matter: evaluating policy choices for reactive nitrogen in the Chesapeake Bay Watershed, Environ. Sci. Technol., 45, 168-174, doi:10.1021/es101472z, 2011.

Blackall, T. D., Wilson, L. J., Theobald, M. R., Milford, C., Nemitz, E., Bull, J., Bacon, P. J., Hamer, K. C., Wanless, S., and Sutton, M. A.: Ammonia emissions from seabird colonies, Geophys. Res. Lett., 34, L10801, doi:10.1029/2006GL028928, 2007.

Blais, M., Tremblay, J.-É., Jungblut, A. D., Gagnon, J., Martin, J., Thaler, M., and Lovejoy, C.: Nitrogen fixation and identification of potential diazotrophs in the Canadian Arctic, Global Biogeochem. Cy., 26, GB3022, doi:10.1029/2011GB004096, 2012.

Błaś, M., Sobik, M., and Twarowski, R.: Changes of cloud water chemical composition in the Western Sudety Mountains, Poland, Atmos. Res., 87, 224-231, doi:10.1016/j.atmosres.2007.11.004, 2008.

Bouwman, A. F., Lee, D. S., Asman, W. A. H., Dentener, F. J., Van Der Hoek, K. W., and Olivier, J. G. J.: A global high-resolution emission inventory for ammonia, Global Biogeochem. Cy., 11, 561-587, doi:10.1029/97GB02266, 1997.

Bouwman, A. F., Beusen, A. H. W., Griffioen, J., Van Groenigen, J. W., Hefting, M. M., Oenema, O., Van Puijenbroek, P. J. T. M., Seitzinger, S., Slomp, C. P., and Stehfest, E.: Global trends and uncertainties in terrestrial denitrification and $\mathrm{N}_{2} \mathrm{O}$ emissions, Philos. T. Roy. Soc. B, 368, 1621, doi:10.1098/rstb.2013.0112, 2013.

Boyd, P. W. and Doney, S. C.: Modelling regional responses by marine pelagic ecosystems to global climate change, Geophys. Res. Lett., 29, 53.1-53.4, doi:10.1029/2001GL014130, 2002.
Brink, C., van Grinsven, H., Jacobsen, B. H., Rabl, A., Green, I.M., Holland, M., Klimont, Z., Hicks, K., Brouwer, R., Dickens, R., Willems, J., Termansen, M., Velthof, G., Alkemade, R., van Oorschot, M., and Webb, J.: Costs and benefits of nitrogen in the environment, in: The European nitrogen assessment. Sources, effects and policy perspectives, edited by: Sutton, M. A., Howard, C. M., Erisman, J. W., Billen, B., Bleeker, A., Grennfelt, P., van Grinsven, H., and Grizzetti, B., Cambridge, UK, Cambridge University Press, Chapter 22, 513-540, 2011.

Brovkin, V., Boysen, L., Arora, V. K., Boiser, J. P., Cadule, P., Chini, L., Claussen, M., Friedlingstein, P., Gayler, V., van den Hurk, B. J. J. M., Hurtt, G. C., Jones, C. D., Kato, E., De NobletDucoudré, N., Pacifico, F., Pongratz, J., and Weiss, M.: Effect of anthropogenic land-use and land-cover changes on climate and land carbon storage in CMIP5 projections for the twentyfirst century, J. Climate, 26, 6859-6881, doi:10.1175/JCLI-D-1200623.1, 2013.

Butterbach-Bahl, K. and Dannenmann, M.: Denitrification and associated soil $\mathrm{N}_{2} \mathrm{O}$ emissions due to agricultural activities in a changing climate, Curr. Opin. Environ. Sustain., 3, 389-395, doi:10.1016/j.cosust.2011.08.004, 2011.

Butterbach-Bahl, K., Baggs, E. M., Dannenmann, M., Kiese, R., and Zechmeister-Boltenstern, S.: Nitrous oxide emissions from soils: how well do we understand the processes and their controls?, Philos. T. Roy. Soc. B, 368, 1621, 20130122, doi:10.1098/rstb.2013.0122, 2013.

Canfield, D. E.: Models of oxic respiration, denitrification and sulfate reduction in zones of coastal upwelling, Geochim. Cosmochim. Ac., 70, 5753-5765, doi:10.1016/j.gca.2006.07.023, 2006.

Cape, J. N., Anderson, M., Rowland, A. P., and Wilson, D.: Organic nitrogen in precipitation across the United Kingdom, Water Air Soil Poll., 4, 25-35, doi:10.1007/s11267-004-3010-8, 2004.

Cape, J. N., Cornell, S. E., Jickells, T. D., and Nemitz, E.: Organic nitrogen in the atmosphere - where does it come from? A review of sources and methods, Atmos. Res., 102, 30-48, doi:10.1016/j.atmosres.2011.07.009, 2011.

Capone, D. G., Zehr, J. P., Paerl, H. W., Bergman, B., and Carpenter, E. J.: Trichodesmium, a Globally Significant Marine Cyanobacterium, Science, 276, 5316, 1221-1229, doi:10.1126/science.276.5316.1221, 1997.

Carpenter, E. J. and Capone, D. G.: Nitrogen fixation in the marine environment, in: Nitrogen in the Marine Environment, 2nd Edn., edited by: Capone, D. G., Bronk, D. A., Mulholland, M. R., and Carpenter, E. J., Academic Press, San Diego, Chapter 4, 141198, 2008.

Chen, H.-Y., Chen, L.-D., Chiang, Z.-Y., Hung, C.-C., Lin, F.-J., Chou, W.-C., Gong, G.-C., and Wen, L.-S.: Size fractionation and molecular composition of water-soluble inorganic and organic nitrogen in aerosols of a coastal environment, J. Geophys. Res., 115, D22307, doi:10.1029/2010JD014157, 2010.

Chen, X., Cui, Z., Fan, M., Vitousek, P., Zhao, M., Ma, W., Wang, Z., Zhang, W., Yan, X., Yang, J., Deng, X., Gao, Q., Zhang, Q., Guo, S., Ren, J., Li, S., Ye, Y., Wang, Z., Huang, J., Tang, Q., Sun, Y., Peng, X., Zhang, J., He, M., Zhu, Y., Xue, J., Wang, G., Wu, L., An, N., Wu, L., Ma, L., Zhang, W., and Zhang, F.: Producing more grain with lower environmental costs, Nature, 514, 486-489, doi:10.1038/nature13609, 2014. 
Ciais, P., Sabine, C., Bala, G., Bopp, L., Brovkin, V., Canadell, J., Chhabra, A., DeFries, R., Galloway, J., Heimann, M., Jones, C., Le Quéré, C., Myneni, R. B., Piao, S., and Thornton, P.: Carbon and other biogeochemical cycles, in: Climate Change 2013: The physical science basis. Working Group I contribution to the to the Fifth Assessment Report of the Intergovernmental Panel on Climate Change (IPCC), edited by: Stocker, T. F., Qin, D., Plattner, G.-K., Tignor, M. M. B., Allen, S. K., Boschung, J., Nauels, A., Xia, Y., Bex, V., and Midgley, P. M., Cambridge University Press, Chapter 6, 467-570, 2013.

Cleveland, C. C., Townsend, A. R., Schimel, D. S., Fisher, H., Howarth, R. W., Hedin, L. O., Perakis, S. S., Latty, E. F., von Fischer, J. C., Elseroad, A., and Wasson, M. F.: Global patterns of terrestrial biological nitrogen $\left(\mathrm{N}_{2}\right)$ fixation in natural ecosystems, Global Biogeochem. Cy., 13, 623-645, doi:10.1029/1999GB900014, 1999.

Comiso, J. C.: Large decadal decline of the Arctic multiyear ice cover, J. Climate, 25, 1176-1193, doi:10.1175/JCLI-D-1100113.1, 2012.

Compton, J. E., Harrison, J. A., Dennis, R. L., Greaver, T. L., Hill, B. H. Jordan, S. J., Walker, H., and Campbell, H. V.: Ecosystem services altered by human changes in the nitrogen cycle: a new perspective for US decision making, Ecol. Lett., 14, 804-815, doi:10.1111/j.1461-0248.2011.01631.x, 2011.

Conrad, R.: Metabolism of nitric oxide in soil and soil microorganisms and regulation of flux into the atmosphere, in: Microbiology of atmospheric trace gases, edited by: Murrell, J. C. and Kelly, D. P., NATO ASI Series, Springer, Berlin, 109, 167-203, doi:10.1007/978-3-642-61096-7_11, 1996.

Corbett, J. J., Lack, D. A., Winebrake, J. J., Harder, S., Silberman, J. A., and Gold, M.: Arctic shipping emissions inventories and future scenarios, Atmos. Chem. Phys., 10, 9689-9704, doi:10.5194/acp-10-9689-2010, 2010.

Cornell, S., Mace, K., Coeppicus, S., Duce, R., Huebert, B., Jickells, T. and Zhuang, L. Z.: Organic nitrogen in Hawaiian rain and aerosol, J. Geophys. Res., 106, 7973-7983, doi:10.1029/2000JD900655, 2001.

Cornell, S. E.: Atmospheric nitrogen deposition: revising the question of the importance of the organic component, Environ. Pollut., 159, 2214-2222, doi:10.1016/j.envpol.2010.11.014, 2011.

Cornell, S. E., Jickells, T. D., Cape, J. N., Rowland, A. P., and Duce, R. A.: Orgnic nitrogen deposition on land and coastal invironments: a review of methods and data, Atmos. Environ., 37, 21732191, doi:10.1016/S1352-2310(03)00133-X, 2003.

Cottrell, B. A., Gonsior, M., Isabelle, L. M., Luo, W., Perraud, V., McIntire, T. M., Pankow, J. F., Schmitt-Kopplin, P., Cooper, W. J., and Simpson, A. J.: A regional study of the seasonal variation in the molecular composition of rainwater, Atmos. Environ, 77, 588-597, doi:10.1016/j.atmosenv.2013.05.027, 2013.

Cox, R. A. and Roffey, M. J.: Thermal decomposition of peroxyacetylnitrate in the presence of nitric oxide, Environ. Sci.Technol., 11, 900-906, doi:10.1021/es60132a010, 1977.

Davidson, C. I., Miller, J. M., and Pleskow, M. A.: The influence of surface structure on predicted particle dry deposition to natural grass canopies, Water Air Soil Poll., 18, 25-43, doi:10.1007/BF02419401, 1982.

Davidson, E. A. and Kanter, D.: Inventories and scenarios of nitrous oxide emissions, Environ. Res. Lett., 9, 105012, doi:10.1088/1748-9326/9/10/105012, 2014.
Davidson, E. A., de Carvalho, C. J. R., Figueira, A. M., Ishida, F. Y., Ometto, J. P. H. B., Nardoto, G. B., Sabá, R. T., Hayashi, S. N., Leal, E. C., Vieira, I. C. G., and Martinelli, L. A.: Recuperation of nitrogen cycling in Amazonian forests following agricultural abandonment, Nature, 447, 995-998, doi:10.1038/nature05900, 2007.

Davidson, E. A., David, M. B., Galloway, J. N., Goodale, C. L., Haeuber, R., Harrison, J. A., Howarth, R.W., Jaynes, D. B., Lowrance, R. R., Nolan, B. T., Peel, J. L., Pinder, R. W., Porter E., Snyder, C. S., Townsend, A. R., and Ward, M. H.: Excess nitrogen in the U.S. environment: trends, risks, and solutions, Issues in Ecology, Report Number 15, Ecological Society of America, 1-16, 2012.

De Haan, D. O., Hawkins, L. N., Kononenko, J. A., Turley, J. J., Corrigan, A. L., Tolbert, M. A., and Jimenez, J. L.: Formation of nitrogen-containing oligomers by methylglyoxal and amines in simulated evaporating cloud droplets, Environ. Sci. Technol., 45, 984-991, doi:10.1021/es102933x, 2011.

Denman, K. L., Brasseur, G., Chidthaisong, A., Ciais, P., Cox, P. M., Dickinson, R. E., Hauglustaine, D., Heinze, C., Holland, E., Jacob, D., Lohmann, U., Ramachandran, S., da Silva Dias, P. L., Wofsy, S. C., and Zhang, X.: Couplings between changes in the climate system and biogeochemistry, in: Climate Change 2007: The physical science basis. Contribution of Working Group I to the Fourth Assessment Report of the Intergovernmental Panel on Climate Change, edited by: Solomon, S., Qin, D., Manning, M., Chen, Z., Marquis, M., Averyt, K. B., Tignor, M., and Miller, H. L., Cambridge University Press, Cambridge, United Kingdom and New York, NY, USA, Chapter 7, 499-587, 2007.

Dentener, F. J. and Crutzen, P. J.: A three-dimensional model of the global ammonia cycle, J. Atmos. Chem., 19, 331-369, doi:10.1007/BF00694492, 1994.

Derwent, R. G., Collins, W. J., Jenkin, M. E., Johnson, C. E., and Stevenson, D. S.: The global distribution of secondary particulate matter in a 3-D Lagrangian chemistry transport model, J. Atmos. Chem., 44, 57-95, doi:10.1023/A:1022139814102, 2003.

Desyaterik, Y., Sun, Y., Shen, X. H., Lee, T. Y., Wang, X. F., Wang, T., and Collett, J. L.: Speciation of "brown" carbon in cloud water impacted by agricultural biomass burning in eastern China, J. Geophys. Res.-Atmos., 118, 7389-7399, doi:10.1002/jgrd.50561, 2013.

Deutsch, C., Sarmiento, J. L., Sigman, D. M., Gruber, N., and Dunne, J. P.: Spatial coupling of nitrogen inputs and losses in the ocean, Nature, 445, 163-167, doi:10.1038/nature05392, 2007.

De Vries, W., Du, E., and Butterbach-Bahl, K.: Short and longterm impacts of nitrogen deposition on carbon sequestration by forest ecosystems, Curr. Opin. Environ. Sustain., 9-10, 90-104, doi:10.1016/j.cosust.2014.09.001, 2014.

Doherty, R. M., Wild, O., Shindell, D. T., Zeng, G., MacKenzie, I. A., Collins, W. J., Fiore, A. M., Stevenson, D. S., Dentener, F. J., Schultz, M. G., Hess, P., Derwent, R. G., and Keating, T. J.: Impacts of climate change on surface ozone and intercontinental ozone pollution: A multi-model study, J. Geophys. Res.-Atmos, 118, 3744-3763, doi:10.1002/jgrd.50266, 2013.

Doskey, P. V., Kotamarthi, V. R., Fukui, Y., Cook, D. R., Breitbeil III, F. W., and Wesely, M. L.: Air-surface exchange of peroxyacetyl nitrate at a grassland site, J. Geophys. Res.-Atmos., 109, D10310, doi:10.1029/2004JD004533, 2004. 
Drake, J. E., Gallet-Budynek, A., Hofmockel, K. S., Bernhardt, E. S., Billings, S. A., Jackson, R. B., Johnson, K. S., Lichter, J., McCarthy, H. R., McCormack, M. L., Moore, D. J. P., Oren, R., Palmroth, S., Phillips, R. P., Pippen, J. S., Pritchard, S. G., Treseder, K. K., Schlesinger, W. H., DeLucia, E. H., and Finzi, A. C.: Increases in the flux of carbon belowground stimulate nitrogen uptake and sustain the long-term enhancement of forest productivity under elevated $\mathrm{CO}_{2}$, Ecol. Lett., 14, 349-357, doi:10.1111/j.1461-0248.2011.01593.x, 2011.

Duan, F.-K., Liu, X.-D., He, K.-B., and Dong, S.-P.: Measurements and characteristics of nitrogen-containing compounds in atmospheric particulate matter in Beijing, China, B. Environ. Contam. Tox., 82, 332-337, doi:10.1007/s00128-008-9560-0, 2009.

Duce, R. A., LaRoche, J., Altieri, K., Arrigo, K. R., Baker, A. R., Capone, D. G., Cornell, S., Dentener, F., Galloway, J., Ganeshram, R. S., Geider, R. J., Jickells, T., Kuypers, M. M., Langlois, R., Liss, P. S., Liu, S. M., Middelburg, J. J., Moore, C. M., Nickovic, S., Oschlies, A., Pedersen, T., Prospero, J., Schlitzer, R., Seitzinger, S., Sorensen, L. L., Uematsu, M., U1loa, O., Voss, M., Ward, B., and Zamora, L.: Impacts of atmospheric anthropogenic nitrogen on the open ocean, Science, 320 , 893-897, doi:10.1126/science.1150369, 2008.

Duyzer, J. H., Dorsey, J. R., Gallagher, M. W., Pilegaard, K., and Walton, S.: Oxidized nitrogen and ozone interaction with forests. II: multi-layer process-oriented modelling results and a sensitivity study for Douglas fir, Q. J. Roy. Meteor. Soc., 130, 19571971, doi:10.1256/qj.03.125, 2004.

Ederli, L., Morettini, R., Borgogni, A., Wasternack, C., Miersch, O., Reale, L., Ferranti, F., Tosti, N., and Pasqualini, S.: Interaction between nitric oxide and ethylene in the induction of alternative oxidase in ozone-treated tobacco plants, Plant Physiol., 142, 595-608, doi:10.1104/pp.106.085472, 2006.

EEA: Air quality in Europe - 2012 report, EEA report no. 4/2012, European Environment Agency, Copenhagen, Denmark, 104 pp., doi:10.2800/55823, 2012.

Elbert, W., Weber, B., Burrows, S., Steinkamp, J., Budel, B., Andreae, M. O., and Pöschl, U.: Contribution of cryptogamic covers to the global cycles of carbon and nitro-gen, Nat. Geosci., 5, 459-462, 2012.

EMEP: Transboundary particulate matter, photo-oxidants, acidifying and eutrophying componenets, EMEP Status Report 1/2014 (29 August 2014), 2014.

Engardt, M. and Langner, J.: Simulations of future sulphur and nitrogen deposition over Europe using meteorological data from three regional climate projections, Tellus B, 65, 20348, doi:10.3402/tellusb.v65i0.20348, 2013.

Erisman, J. W., Domburg, N., de Vries, W., Kros, H., de Haan, and Band Sanders, K.: The Dutch N-cascade in the European perspective, Science in China Series C: Life Sciences, 48, 827-842, doi:10.1007/BF03187122, 2005.

Erisman, J. W., Sutton, M. A., Galloway, J., Klimont, Z., and Winiwarter, W.: How a century of ammonia synthesis changed the world, Nat. Geosci., 1, 636-639, doi:10.1038/ngeo325, 2008.

Erisman, J. W., Galloway, J. N., Seitzinger, S., Bleeker, A., Dise, N. B., Petrescu, A. M. R., Leach, A. M., and de Vries, W.: Consequences of human modification of the global nitrogen cycle, Philos. T. Roy. Soc. B, 368, 1621, 20130116, doi:10.1098/rstb.2013.0116, 2013.
Eugster, O. and Gruber, N.: A probabilistic estimate of global marine $\mathrm{N}$-fixation and denitrification, Global Biogeochem. Cy., 26, GB4013, doi:10.1029/2012GB004300, 2012.

Facchini, M. C., Decesari, S., Rinaldi, M., Carbone, C., Finessi, E., Mircea, M., Fuzzi, S., Moretti, F., Tagliavini, E., Ceburnis, D., and O'Dowd, C. D.: Important source of marine secondary organic aerosol from biogenic amines, Environ. Sci. Technol., 42, 9116-9121, doi:10.1021/es8018385, 2008.

FAO: Food and Agriculture Organisation's Statistical Database, FAOSTAT, Rome, available at: http://faostat.fao.org/site/291/ default.aspx (last access: 10 December 2015), 2012.

Farmer, D. K. and Cohen, R. C.: Observations of $\mathrm{HNO}_{3}, \mathrm{SAN}$, SPN and NO2 fluxes: evidence for rapid $\mathrm{HO}_{\mathrm{x}}$ chemistry within a pine forest canopy, Atmos. Chem. Phys., 8, 3899-3917, doi:10.5194/acp-8-3899-2008, 2008.

Farquhar, G. D., Firth, P. M., Wetselaar, R., and Weir, B.: On the gaseous exchange of ammonia between leaves and the environment: determination of the ammonia compensation point, Plant Physiol., 66, 710-714, doi:10.1104/pp.66.4.710, 1980.

Feick, G. and Hainer, R. M.: On the thermal decomposition of ammonium nitrate. Steady-state reaction temperatures and reaction rate, J. Am. Chem. Soc., 76, 22, 5860-5863, doi:10.1021/ja01651a096, 1954.

Felle, H. H. and Hanstein, S.: The apoplastic pH of the substomatal cavity of Vicia faba leaves and its regulation responding to different stress factors, J. Exp. Bot., 53, 73-82, doi:10.1093/jexbot/53.366.73, 2002.

Finzi, A. C., Norby, R. J., Calfapietra, C., Gallet-Budynek, A., Gielen, B., Holmes, W. E., Hoosbeek, M. R., Iverson, C. M., Jackson, R. B., Kubiske, M. E., Fedford, J., Liberloo, M., Oren, R., Polle, A., Pritchard, S., Zak, D.R., Schlesinger, W. H., and Ceulemans, R.: Increases in nitrogen uptake rather than nitrogen-use efficiency support higher rates of temperate forest productivity under elevated $\mathrm{CO}_{2}$, P. Natl. Acad. Sci. USA, 104, 14014-14019, doi:10.1073/pnas.0706518104, 2007.

Flechard, C. R. and Fowler, D.: Atmospheric ammonia at a moorland site. II: Long-term surface-atmosphere micrometeorological flux measurements, Q. J. Roy. Meteor. Soc., 124, 759-791, doi:10.1002/qj.49712454706,1998.

Flechard, C. R., Fowler, D., Sutton, M. A., and Cape, J. N.: A dynamic chemical model of bi-directional ammonia exchange between semi-natural vegetation and the atmosphere, Q. J. Roy. Meteor. Soc., 125, 2611-2641, doi:10.1002/qj.49712555914, 1999.

Flechard, C. R., Spirig, C., Neftel, A., and Ammann, C.: The annual ammonia budget of fertilised cut grassland - Part 2: Seasonal variations and compensation point modeling, Biogeosciences, 7 , 537-556, doi:10.5194/bg-7-537-2010, 2010.

Flechard, C. R., Nemitz, E., Smith, R. I., Fowler, D., Vermeulen, A. T., Bleeker, A., Erisman, J. W., Simpson, D., Zhang, L., Tang, Y. S., and Sutton, M. A.: Dry deposition of reactive nitrogen to European ecosystems: a comparison of inferential models across the NitroEurope network, Atmos. Chem. Phys., 11, 2703-2728, doi:10.5194/acp-11-2703-2011, 2011.

Flechard, C. R., Massad, R.-S., Loubet, B., Personne, E., Simpson, D., Bash, J. O., Cooter, E. J., Nemitz, E., and Sutton, M. A.: Advances in understanding, models and parameterizations of biosphere-atmosphere ammonia exchange, Biogeosciences, 10, 5183-5225, doi:10.5194/bg-10-5183-2013, 2013. 
Fowler, D., Pitcairn, C. E. R., Sutton, M. A., Flechard, C., Loubet, B., Coyle, M., and Munro, R. C.: The mass budget of atmospheric ammonia in woodland within $1 \mathrm{~km}$ of livestock buildings, Environ. Pollut., 102, 343-348, doi:10.1016/S02697491(98)80053-5, 1998.

Fowler, D., Morse, A. P., Gallagher, M. W., and Choularton, T. W.: Measurements of cloud water deposition on vegetation using a lysimeter and a flux gradient technique, Tellus 42, 285-293, doi:10.1034/j.1600-0889.1990.t01-1-00007.x, 1990.

Fowler, D., Pilegaard, K., Sutton, M. A., Ambus, P., Raivonen, M., Duyzer, J., Simpson, D., Fagerli, H., Fuzzi, S., Schjoerring, J. K., Granier, C., Neftel, A., Isaksen, I. S. A., Laj, P., Maione, M., Monks, P. S., Burkhardt, J., Daemmgen, U., Neirynck, J., Personne, E., Wichink-Kruit, R., Butterbach-Bahl, K., Flechard, C., Tuovinen, J. P., Coyle, M., Gerosa, G., Loubet, B., Altimir, N., Gruenhage, L., Ammann, C., Cieslik, S., Paoletti, E., Mikkelsen, T. N., Ro-Poulsen, H., Cellier, P., Cape, J. N., Horváth, L., Loreto, F., Niinemets, Ü ., Palmer, P. I., Rinne, J., Misztal, P., Nemitz, E., Nilsson, D., Pryor, S., Gallagher, M. W., Vesala, T., Skiba, U., Brüggemann, N., Zechmeister-Boltenstern, S., Williams, J., O’Dowd, C., Facchini, M. C., de Leeuw, G., Flossman, A., Chaumerliac, N., and Erisman, J. W.: Atmospheric composition change: Ecosystems-Atmosphere interactions, Atmos. Environ., 43, 5193-5267, doi:10.1016/j.atmosenv.2009.07.068, 2009.

Fowler, D., Coyle, M., Skiba, U., Sutton, M. A., Cape, J. N., Reis, S., Sheppard, L. J., Jenkins, A., Grizzetti, B., Galloway, J. N., Vitousek, P., Leach, A., Bouwman, A. F., Butterbach-Bahl, K., Dentener, F., Stevenson, D., Amann, M., and Voss, M.: The global nitrogen cycle in the twenty-first century, Philos. T. Roy. Soc. B, 368, 1621, doi:10.1098/rstb.2013.0164, 2013.

Fry, J. L., Draper, D. C., Zarzana, K. J., Campuzano-Jost, P., Day, D. A., Jimenez, J. L., Brown, S. S., Cohen, R. C., Kaser, L., Hansel, A., Cappellin, L., Karl, T., Hodzic Roux, A., Turnipseed, A., Cantrell, C., Lefer, B. L., and Grossberg, N.: Observations of gas- and aerosol-phase organic nitrates at BEACHON-RoMBAS 2011, Atmos. Chem. Phys., 13, 8585-8605, doi:10.5194/acp-138585-2013, 2013.

Fu, F.-X. and Bell, P. R. F.: Effect of salinity on growth, pigmentation, $\mathrm{N}_{2}$ fixation and alkaline phosphatase activity of cultured Trichodesmium sp., Mar. Ecol.-Prog Ser., 257, 69-76, doi:10.3354/meps257069, 2003.

Fu, F.-X., Mulholland, M. R., Garcia, N. S., Beck, A., Bernhardt, P. W., Warner, M. E., Sanudo-Wilhelmy, S. A., and Hutchins, D. A.: Interactions between changing $\mathrm{pCO}_{2}, \mathrm{~N}_{2}$ fixation, and Fe limitation in the marine unicellular cyanobacterium Crocosphaera, Limnol. Oceanogr., 53, 2472-2484, doi:10.4319/lo.2008.53.6.2472, 2008.

Fu, F., Yu, E., Garcia, N. S., Gale, J., Luo, Y., Webb, E. A., and Hutchins, D. A.: Differing responses of marine $\mathrm{N}_{2}$ fixers to warming and consequences for future diazotroph community structure, Aquat. Microb. Ecol., 72, 33-46, doi:10.3354/ame01683, 2014.

Galloway, J. N., Aber, J. D., Erisman, J. W., Seitzinger, S. P., Howarth, R. W., Cowling, E. B., and Cosby, J.: The nitrogen cascade, BioScience, 53, 341-356, doi:10.1641/00063568(2003)053[0341:TNC]2.0.CO;2, 2003.

Galloway, J. N., Dentener, F. J., Capone, D. G., Boyer, E. W., Howarth, R. W., Seitzinger, S. P., Asner, G. P., Cleveland, C.
C., Green, P. A., Holland, E. A., Karl, D. M., Michaels, A. F., Porter, J. H., Townsend, A. R., and Vörösmarty, C. J.: Nitrogen cycles: past, present, and future, Biogeochemistry, 70, 153-226, doi:10.1007/s10533-004-0370-0, 2004.

Ganzeveld, L., Bouwman, A., Stehfest, E., van Vuuren, D. P., Eickhout, B., and Lelieveld, J.: Impact of future land use and land cover changes on atmospheric chemistry-climate interactions, J. Geophys. Res., 115, D23301, doi:10.1029/2010JD014041, 2010.

Godfray, H. C. J., Beddington, J. R., Crute, I. R., Haddad, L., Lawrence, D., Muir, J. F., Pretty, J., Robinson, S., Thomas, S. M., and Toulmin, C.: Food security: The challenge of feeding 9 billion people, Science, 327, 812-818, doi:10.1126/science.1185383, 2010.

Gorzelska, K. and Galloway, J. N.: Amine nitrogen in atmospheric environment over the North Atlantic ocean, Global Biogeochem. Cy., 4, 309-333, doi:10.1029/GB004i003p00309, 1990.

Gregory, J. M., Jones, C. D., Cadule, P., and Friedlingstein, P.: Quantifying carbon cycle feedbacks, J. Climate, 22, 5232-5250, doi:10.1175/2009JCLI2949.1, 2009.

Groffman, P. M., Altabet, M. A., Böhlke, J. K., ButterbachBahl, K., David, M. B., Firestone, M. K., Giblin, A. E., Kana, T. M., Nielsen, L. P., and Voytek, M. A.: Methods for measuring denitrification: Diverse approaches to a difficult problem, Ecol. Appl., 16, 2091-2122, doi:10.1890/10510761(2006)016[2091:MFMDDA]2.0.CO;2, 2006.

Groffman, P. M., Butterbach-Bahl, K., Fulweiler, R. W., Gold, A. J., Morse, J. L., Stander, E. K., Tague, C., Tonitto, C., and Vidon, P.: Challenges to incorporating spatially and temporally explicit phenomena (hotspots and hot moments), Biogeochemistry, 93, 49-77, doi:10.1007/s 10533-008-9277-5, 2009.

Großkopf, T., Mohr, W., Baustian, T., Schunck, H., Gill, D., Kuypers, M. M. M., Lavik, G., Schmitz, R. A., Wallace, D. W. R., and LaRoche, J.: Doubling of marine dinitrogen-fixation rates based on direct measurements, Nature, 488, 361-364, doi:10.1038/nature11338, 2012.

Guo, L. B. and Gifford, R. M.: Soil carbon stocks and land use change: a meta analysis, Global Change Biol., 8, 345-360, doi:10.1046/j.1354-1013.2002.00486.x, 2002.

Hauglustaine, D. A., Balkanski, Y., and Schulz, M.: A global model simulation of present and future nitrate aerosols and their direct radiative forcing of climate, Atmos. Chem. Phys., 14, 1103111063, doi:10.5194/acp-14-11031-2014, 2014.

Hedegaard, G. B., Christensen, J. H., and Brandt, J.: The relative importance of impacts from climate change vs. emissions change on air pollution levels in the 21st century, Atmos. Chem. Phys., 13, 3569-3585, doi:10.5194/acp-13-3569-2013, 2013.

Herridge, D. F., Peoples, M. B., and Boddey, R. M.: Global inputs of biological nitrogen fixation in agricultural systems, Plant Soil, 311, 1-18, doi:10.1007/s11104-008-9668-3, 2008.

Hofmockel, K. S. and Schlesinger, W. H.: Carbon dioxide effects on heterotrophic dinitrogen fixation in a temperate pine forest, Soil Sci. Soc. Am. J., 71, 140-144, doi:10.2136/sssaj2006.110, 2007.

Hofmockel, K. S., Gallet-Budynek, A., McCarthy, H. R., Currie, W. S., Jackson, R. B., and Finzi, A. C.: Sources of increased $\mathrm{N}$ uptake in forest trees growing under elevated $\mathrm{CO}_{2}$ : results of a large-scale ${ }^{15} \mathrm{~N}$ study, Global Change Biol., 17, 3338-3350, doi:10.1111/j.1365-2486.2011.02465.x, 2011. 
Houlton, B. Z., Wang, Y.-P., Vitousek, P. M., and Field, C. B.: A unifying framework for dinitrogen fixation in the terrestrial biosphere, Nature, 454, 327-330, doi:10.1038/nature07028, 2008.

Howarth, R. W. and Cole, J. J.: Molybdenum availability, nitrogen limitation, and phytoplankton growth in natural waters, Science, 229, 653-655, doi:10.1126/science.229.4714.653, 1985.

Hudman, R. C., Moore, N. E., Mebust, A. K., Martin, R. V., Russell, A. R., Valin, L. C., and Cohen, R. C.: Steps towards a mechanistic model of global soil nitric oxide emissions: implementation and space based-constraints, Atmos. Chem. Phys., 12, 7779-7795, doi:10.5194/acp-12-7779-2012, 2012.

Hungate, B. A., Dijkstra, P., Wu, Z., Duval, B. D., Day, F. P., Johnson, D. W., Megonigal, J. P., Brown, A. L. P., and Garland, J. L.: Cumulative response of ecosystem carbon and nitrogen stocks to chronic $\mathrm{CO}_{2}$ exposure in a subtropical oak woodland, New Phytol., 200, 753-766, doi:10.1111/nph.12333, 2013.

Hutchins, D. A., Fu, F.-X., Zhang, Y., Warner, M. E., Feng, Y., Portune, K., Bernhardt, P. W., and Mulholland, M. R.: $\mathrm{CO}_{2}$ control of Trichodesmium $\mathrm{N}_{2}$ fixation, photosynthesis, growth rates, and elemental ratios: Implications for past, present, and future ocean biogeochemistry, Limnol. Oceanogr., 52, 1293-1304, doi:10.4319/lo.2007.52.4.1293, 2007.

Hutchins, D. A., Mulholland, M. R., and Fu, F.-X.: Nutrient Cycles and Marine Microbes in a $\mathrm{CO}_{2}$-Enriched Ocean, Oceanography, 22, 128-145, 2009.

Hutchins, D. A., Fu, F.-X., Webb, E. A., Walworth, N., and Tagliabue, A.: Taxon-specific response of marine nitrogen fixers to elevated carbon dioxide concentrations, Nat. Geosci., 6, 790-795, doi:10.1038/ngeo1858, 2013.

Iinuma, Y., Boge, O., Grafe, R., and Herrmann, H.: Methylnitrocatechols: Atmospheric tracer compounds for biomass burning secondary organic aerosols, Environ. Sci. Technol., 44, 8453-8459, doi:10.1021/es102938a, 2010.

IPCC (Intergovernmental Panel on Climate Change): 2006 IPCC Guidelines for National Greenhouse Gas Inventories, prepared by the National Greenhouse Gas Inventories Programme, edited by: Eggleston, H. S., Buendia, L., Miwa, K., Ngara, T., and Tanube, K., IGES, Japan, 2006.

IPCC (Intergovernmental Panel on Climate Change): Climate Change 2013: The physical science basis. Working group I contribution to the Fifth Assessment Report of the Intergovernmental Panel on Climate Change (IPCC), edited by: Stocker, T. F., Qin, D., Plattner, G.-K., Tignor, M. M. B., Allen, S. K., Boschung, J., Nauels, A., Xia, Y., Bex, V., and Midgley, P. M., Cambridge University Press, 1535 pp., 2013.

Jacobson, M. C., Hansson, H. C., Noone, K. J., and Charlson, R. J.: Organic atmospheric aerosols: review and state of the science, Rev. Geophys., 38, 267-294, doi:10.1029/1998RG000045, 2000.

Jaeglé, L., Steinberger, L., Martin, R. V., and Chance, K.: Global partitioning of $\mathrm{NO}_{x}$ sources using satellite observations: Relative roles of fossil fuel combustion, biomass burning and soil emissions, Faraday Discuss., 130, 407-423, doi:10.1039/b502128f, 2005.

Jarvis, P. G.: The interpretation of the variations in leaf water potential and stomatal conductance found in canopies in the field, Philos. T. Roy. Soc. B, 273, 593-610, doi:10.1098/rstb.1976.0035, 1976.

Jensen, L.S., Schjoerring, J. K., van der Hoek, K. W., Poulsen, H. D., Zevenbergen, J. F., Palliére, C., Lammel, J., Brentrup,
F., Jongbloed, A. W., Willems, J., and van Grinsven, H.: Benefits of nitrogen for food, fibre and industrial production, in: The European Nitrogen Assessment: Sources, effects and policy perspectives, edited by: Sutton, M. A., Howard, C. M., Erisman, J. W., Billen, G., Bleeker, A. Grennfelt, P., van Grinsven, H., and Grizzetti, B., Cambridge University Press, 32-61, 2011.

Jickells, T., Baker, A. R., Cape, J. N., Cornell, S. E., and Nemitz, E.: The cycling of organic nitrogen through the atmosphere, Philos. T. Roy. Soc. B, 368, 20130115, doi:10.1098/rstb.2013.0115, 2013.

Johnson, M. T. and Bell, T. G.: Coupling between dimethylsulfide emissions and the ocean-atmosphere exchange of ammonia, Environ. Chem., 5, 259-267, doi:10.1071/EN08030, 2008.

Johnson, M. T., Liss, P. S., Bell, T. G., Lesworth, T. J., Baker, A. R., Hind, A. J., Jickells, T. D., Biswas, K. F., Woodward, E. M. S., and Gibb, S. W.: Field observations of the ocean-atmosphere exchange of ammonia: Fundamental importance of temperature as revealed by a comparison of high and low latitudes, Global Biogeochem. Cy., 22, GB1019, doi:10.1029/2007GB003039, 2008.

Jones, M. R., Leith, I. D., Fowler, D., Raven, J. A., Sutton, M. A., Nemitz, E., Cape, J. N., Sheppard, L. J., Smith, R. I., and Theobald, M. R.: Concentration-dependent $\mathrm{NH}_{3}$ deposition processes for mixed moorland semi-natural vegetation, Atmos. Environ., 41, 2049-2060, doi:10.1016/j.atmosenv.2006.11.003, 2007.

Jungkunst, H. F., Flessa, H., Scherber, C., and Fiedler, S.: Groundwater level controls $\mathrm{CO}_{2}, \mathrm{~N}_{2} \mathrm{O}$ and $\mathrm{CH}_{4}$ fluxes of three different hydromorphic soil types of a temperate forest ecosystem, Soil Biol. Biochem., 40, 2047-2054, doi:10.1016/j.soilbio.2008.04.015, 2008.

Kammann, C., Müller, C., Grünhage, L., and Jäger, H. J.: Elevated $\mathrm{CO}_{2}$ stimulates $\mathrm{N}_{2} \mathrm{O}$ emissions in permanent grassland, Soil Biol. Biochem., 40, 2194-2205, doi:10.1016/j.soilbio.2008.04.012, 2008.

Kanakidou, M., Duce, R. A., Prospero, J. M., Baker, A. R., BenitizNelson, C., Dentener, F. J., Hunter, K. A., Liss, P. S., Mahowald, N., Okin, G. S., Sarin, M., Tsigaridis, K., Uematsu, M., Zamora, L. M., and Zhu, T.: Atmospheric fluxes of organic $\mathrm{N}$ and $\mathrm{P}$ to the global ocean, Glob. Biogeochem. Cy., 26, GB3026, doi:10.1029/2011GB004277, 2012.

Kicklighter, D. W., Cai, Y., Zhuang, Q., Parfenova, E. I., Paltsev, S., Sokolov, A. P., Melillo, J. M., Reilly, J. M., Tchebakova, N. M., and Lu, X.: Potential influence of climate-induced vegetation shifts on future land use and associated land carbon fluxes in Northern Eurasia. Environ. Res. Lett., 9, 035004, doi:10.1088/1748-9326/9/3/035004, 2014.

Kieloaho, A. J., Hellen, H., Hakola, H., Manninen, H. E., Nieminen, T., Kulmala, M., and Pihlatie, M.: Gas-phase alkylamines in a boreal Scots pine forest air, Atmos. Environ., 80, 369-377, doi:10.1016/j.atmosenv.2013.08.019, 2013.

Kirkby, J., Curtius, J., Almeida, J., Dunne, E., Duplissy, J., Ehrhart, S., Franchin, A., Gagné, S., Ickes, L., Kürten, A., Kupc, A., Metzger, A., Riccobono, F., Rondo, L., Schobesberger, S., Tsagkogeorgas, G., Wimmer, D., Amorim, A., Bianchi, F., Breitenlechner, M., David, A., Dommen, J., Downard, A., Ehn, M., Flagan, R. C., Haider, S., Hansel, A., Hauser, D., Jud, W., Junninen, H., Kreissl, F., Kvashin, A., Laaksonen, A., Lehtipalo, K., Lima, J., Lovejoy, E. R., Makhmutov, V., Mathot, S., Mikkilä, Minginette, P., Mogo, S., Nieminen, T., Onnela, A., Pereira, P., 
Petäjä, Schnitzhofer, R., Seinfeld, J. H., Sipilä, M., Stozhkov, Y., Stratmann, F., Tomé, A., Vanhanen, J., Viisanen, Y., Vrtala, A., Wagner, P. E., Walther, H., Weingartner, E., Wex, H., Winkler, P. M., Carslaw, K. S., Worsnop, D. R., Baltensperger, U., and Kulmala, M.: Role of sulphuric acid, ammonia and galactic cosmic rays in atmospheric aerosol nucleation, Nature, 476, 429-433, doi:10.1038/nature10343, 2011.

Kirschbaum, M. U. F., Guo, L. B., and Gifford, R. M.: Why does rainfall affect the trend in soil carbon after converting pastures to forests?: A possible explanation based on nitrogen dynamics, Forest Ecol. Manag., 255, 2990-3000, doi:10.1016/j.foreco.2008.02.005, 2008.

Kirschbaum, M. U. F., Saggar, S., Tate, K. R., Thakur, K. P., and Giltrap, D. L.: Quantifying the climate-change consequences of shifting land use between forest and agriculture, Sci. Total Environ., 465, 314-324, doi:10.1016/j.scitotenv.2013.01.026, 2013.

Kjellstrom, E., Nikulin, G., Hansson, U., Strandberg, G., and Ullerstig, A.: 21st century changes in the European climate: uncertainties derived from an ensemble of regional climate model simulations, Tellus A, 63, 24-40, doi:10.1111/j.16000870.2010.00475.x, 2011.

Kourtchev, I., O’Connor, I. P., Giorio, C., Fuller, S. J., Kristensen, K., Maenhaut, W., Wenger, J. C., Sodeau, J. R., Glasius, M., and Kalberer, M.: Effects of anthropogenic emissions on the molecular composition of urban organic aerosols: An ultrahigh resolution mass spectrometry study, Atmos. Environ., 89, 525-532, doi:10.1016/j.atmosenv.2014.02.051, 2014.

Kranz, S., Sültemeyer, D., Richter, K.-U., and Rost, B.: Carbon acquisition in Trichodesmium: The effect of $\mathrm{pCO}_{2}$ and diurnal changes, Limnol. Oceanogr., 54, 548-559, doi:10.4319/lo.2009.54.2.0548, 2009.

Kryza, M., Werner, M., Dore, A. J., Błaś, M., and Sobik, M.: The role of annual circulation and precipitation on national scale deposition of atmospheric sulphur and nitrogen compounds, J. Environ. Manage., 109, 70-79, doi:10.1016/j.jenvman.2012.04.048, 2012.

Kunwar, B. and Kawamura, K.: One-year observations of carbonaceous and nitrogenous components and major ions in the aerosols from subtropical Okinawa Island, an outflow region of Asian dusts, Atmos. Chem. Phys., 14, 1819-1836, doi:10.5194/acp-141819-2014, 2014.

Kurtén, T., Loukonen, V., Vehkamäki, H., and Kulmala, M.: Amines are likely to enhance neutral and ion-induced sulfuric acid-water nucleation in the atmosphere more effectively than ammonia, Atmos. Chem. Phys., 8, 4095-4103, doi:10.5194/acp-8-4095-2008, 2008.

Laitinen, T., Junninen, H., Parshintsev, J., Ruiz-Jimenez, J., Petäjä, T., Hautala, S., Hartonen, K., Worsnop, D., Kulmala, M., and Riekkola, M. L.: Changes in concentration of nitrogen-containing compounds in $10 \mathrm{~nm}$ particles of boreal forest atmosphere at snowmelt, J. Aerosol Sci., 70, 1-10, doi:10.1016/j.jaerosci.2013.12.009, 2014.

Lamarque, J.-F., Kiehl, J. T., Brasseur, G. P., Butler, T., CameronSmith, P., Collins, W. D., Collins, W. J., Granier, C., Hauglustaine, D., Hess, P. G., Holland, E. A., Horowitz, L., Lawrence, M. G., McKenna, D., Merilees, P., Prather, M. J., Rasch, P. J., Rotman, D., Shindell, D., and Thornton, P.: Assessing future nitrogen deposition and carbon cycle feedback using a multimodel approach: Analysis of nitrogen deposition, J. Geophys. Res., 110, D19303, doi:10.1029/2005JD005825, 2005.

Lamarque, J.-F., Kyle, G. P., Meinshausen, M., Riahi, K., Smith, S. J., van Vuuren, D. P., Conley, A. J., and Vitt, F.: Global and regional evolution of short-lived radiatively-active gases and aerosols in the Representative Concentration Pathways, Climatic Change, 109, 191-212, doi:10.1007/s10584-011-0155-0, 2011.

Lamarque, J.-F., Dentener, F., McConnell, J., Ro, C.-U., Shaw, M., Vet, R., Bergmann, D., Cameron-Smith, P., Dalsoren, S., Doherty, R., Faluvegi, G., Ghan, S. J., Josse, B., Lee, Y. H., MacKenzie, I. A., Plummer, D., Shindell, D. T., Skeie, R. B., Stevenson, D. S., Strode, S., Zeng, G., Curran, M., Dahl-Jensen, D., Das, S., Fritzsche, D., and Nolan, M.: Multi-model mean nitrogen and sulfur deposition from the Atmospheric Chemistry and Climate Model Intercomparison Project (ACCMIP): evaluation of historical and projected future changes, Atmos. Chem. Phys., 13, 7997-8018, doi:10.5194/acp-13-7997-2013, 2013.

LeClair, J. P., Collett, J. P., and Mazzoleni L. R.: Fragmentation analysis of water-soluble atmospheric organic matter using ultrahigh-resolution FT-ICR mass spectrometry, Environ. Sci. Technol., 46, 4312-4322, doi:10.1021/es203509b, 2012.

Ledgard, S. F. and Steele, K. W.: Biological nitrogen-fixation in mixed legume grass pastures, Plant Soil, 141, 137-153, doi:10.1007/BF00011314, 1992.

Lee, A. K. Y., Zhao, R., Li, R., Liggio, J., Li, S.-M., and Abbatt, J. P. D.: Formation of light absorbing organo-nitrogen species from evaporation of droplets containing glyoxal and ammonium sulfate. Environ. Sci. Technol., 47 12819-12826, doi:10.1021/es402687w, 2013.

Lesworth, T., Baker, A. R., and Jickells, T.: Aerosol organic nitrogen over the remote Atlantic Ocean, Atmos. Environ., 44, 18871893, doi:10.1016/j.atmosenv.2010.02.021, 2010.

Levitan, O., Rosenberg, G., Setlik, I., Setlikova, E., Grigel, J., Klepetar, J., Prasil, O., and Berman-Frank, I.: Elevated $\mathrm{CO}_{2}$ enhances nitrogen fixation and growth in the marine cyanobacterium Trichodesmium, Global Change Biol., 13, 531-538, doi:10.1111/j.1365-2486.2006.01314.x, 2007.

Li, Q. F. and Yu, J. Z.: Determination of total aerosol nitrogen by thermal evolution, Aerosol Sci. Tech., 38, 382-390, doi:10.1080/02786820490442626, 2004.

Liao, H., Chen, W. T., and Seinfeld, J. H.: Role of climate change in global predictions of future tropospheric ozone and aerosols, J. Geophys. Res., 111, D12304, doi:10.1029/2005jd006852, 2006.

Liss, P. S. and Slater, P. G.: Flux of Gases across the Air- Sea Interface, Nature, 247, 181-184, doi:10.1038/247181a0, 1974.

Liu, C., Zheng, X., Zhou, Z., Han, S., Wang, Y., Wang, K., Liang, W., Li, M., Chen, D., and Yang, Z.: Nitrous oxide and nitric oxide emissions from an irrigated cotton field in Northern China, Plant Soil, 332, 123-134, doi:10.1007/s11104-009-0278-5, 2010.

Logan, J. A.: Nitrogen oxides in the troposphere: Global and regional budgets, J. Geophys. Res., 88, 10785-10807, doi:10.1029/JC088iC15p10785, 1983.

Long, S. P., Ainsworth, E. A., Rogers, A., and Ort, D. R.: Rising atmospheric carbon dioxide: plants FACE the future. Annu. Rev. Plant Biol., 55, 591-628, doi:10.1146/annurev.arplant.55.031903.141610, 2004.

Loubet, B., Milford, C., Sutton, M. A., and Cellier, P.: Investigation of the interaction between sources and sinks of atmospheric ammonia in an upland landscape using a simpli- 
fied dispersion-exchange model, J. Geophys. Res., 106, 2418324195, doi:10.1029/2001JD900238, 2001.

Loubet, B., Asman, W. A., Theobald, M. R., Hertel, O., Tang, Y. S., Robin, P., Hassouna, M., Dämmgen, U., Genermont, S., Cellier, P., and Sutton, M. A.: Ammonia deposition near hot spots: Processes, models and monitoring methods, in: Atmospheric ammonia. Detecting emissions changes and environmental impacts, edited by: Sutton, M. A., Reis, S., and Baker, S. M., Springer, 205-267, doi:10.1007/978-1-4020-9121-6_15, 2009.

Ludwig, J., Meixner, F. X., Vogel, B., and Forstner, J.: Soil-air exchange of nitric oxide: an overview of processes, environmental factors and modeling studies, Biogeochemistry, 52, 225-257, doi:10.1023/A:1006424330555, 2001.

Luo, C., Rodriguez, R. L. M., Johnston, E. R, Wu, L., Cheng, L., Xue, K., Tu, Q., Deng, Y., He, Z., Shi, J. Z., Yuan, M. M., Sherry, R. A., Li, D., Luo, Y., Schuur, E. A. G., Chain, P., Tiedje, J. M., Zhou, J., and Konstantinidis, K. T.: Soil microbial community responses to a decade of warming revealed by comparative metagenomics, Appl. Environ. Microbiol., 80, 1777-1786, doi:10.1128/AEM.03712-13, 2014.

Luo, Y., Melillo, J., Niu, S., Beier, C., Clark, J. S., Classen, A. T., Davidson, E., Dukes, J. S., Evans, R. D., Field, C. B., Czimczik, C. I., Keller, M., Kimball, B. A., Kueppers, L. M., Norby, R. J., Pelini, S. L., Pendall, E., Rastetter, E., Six, J., Smith, M., Tjoelker, M. G., and Torn, M. S.: Coordinated approaches to quantify long-term ecosystem dynamics in response to global change, Global Change Biol., 17, 843-854, doi:10.1111/j.13652486.2010.02265.x, 2011.

Luo, Y.-W., Doney, S. C., Anderson, L. A., Benavides, M., BermanFrank, I., Bode, A., Bonnet, S., Boström, K. H., Böttjer, D., Capone, D. G., Carpenter, E. J., Chen, Y. L., Church, M. J., Dore, J. E., Falcón, L. I., Fernández, A., Foster, R. A., Furuya, K., Gómez, F., Gundersen, K., Hynes, A. M., Karl, D. M., Kitajima, S., Langlois, R. J., LaRoche, J., Letelier, R. M., Marañón, E., McGillicuddy Jr., D. J., Moisander, P. H., Moore, C. M., Mouriño-Carballido, B., Mulholland, M. R., Needoba, J. A., Orcutt, K. M., Poulton, A. J., Rahav, E., Raimbault, P., Rees, A. P., Riemann, L., Shiozaki, T., Subramaniam, A., Tyrrell, T., TurkKubo, K. A., Varela, M., Villareal, T. A., Webb, E. A., White, A. E., Wu, J., and Zehr, J. P.: Database of diazotrophs in global ocean: abundance, biomass and nitrogen fixation rates, Earth Syst. Sci. Data, 4, 47-73, doi:10.5194/essd-4-47-2012, 2012.

Luo, Y.-W., Lima, I. D., Karl, D. M., Deutsch, C. A., and Doney, S. C.: Data-based assessment of environmental controls on global marine nitrogen fixation, Biogeosciences, 11, 691-708, doi:10.5194/bg-11-691-2014, 2014.

Luscher, A., Mueller-Harvey, I., Soussana, J. F., Rees, R. M., and Peyraud, J. L.: Potential of legume-based grassland-livestock systems in Europe: a review, Grass Forage Sci., 69, 206-228, doi:10.1111/gfs.12124, 2014.

Mace, K. A., Duce, R. A., and Tindale, N. W.: Organic nitrogen in rain and aerosol at Cape Grim, Tasmania, Australia, J. Geophys. Res.-Atmos., 108, 4338, doi:10.1029/2002JD003051, $2003 \mathrm{a}$.

Mace, K. A., Artaxo, P., and Duce, R. A.: Water-soluble organic nitrogen in Amazon Basin aerosols during the dry (biomass burning) and wet seasons, J. Geophys. Res.-Atmos., 108, 4512, doi:10.1029/2003JD003557, 2003b.

Mace, K. A., Kubilay, N., and Duce, R. A.: Organic nitrogen in rain and aerosol in the eastern Mediterranean atmosphere: an associa- tion with atmospheric dust, J. Geophys. Res.-Atmos., 108, 4320, doi:10.1029/2002JD002997, 2003c.

MacLeod, M., Moran, D., Eory, V., Rees, R. M., Barnes, A., Topp, C. F. E., Ball, B., Hoad, S., Wall, E., McVittie, A., Pajot, G., Matthews, R., Smith, P., and Moxey, A.: Developing greenhouse gas marginal abatement cost curves for agricultural emissions from crops and soils in the UK, Agr. Syst., 103, 198-209, doi:10.1016/j.agsy.2010.01.002, 2010.

Mahaffey, C., Michaels, A. F., and Capone, D. G.: The conundrum of marine $\mathrm{N}_{2}$ fixation, Am. J. Sci., 305, 546-595, doi:10.2475/ajs.305.6-8.546, 2005.

Marino, R., Howarth, R. W., Chan, F., Cole, J. J., and Likens, G. E.: Sulfate inhibition of molybdenum-dependent nitrogen fixation by planktonic cyanobacteria under sea water conditions: a non-reversible effect, Hydrobiologia, 500, 277-293, doi:10.1023/A:1024641904568, 2003.

Martin, R. V., Jacob, D. J., Chance, K., Kurosu, T. P., Palmer, P. I., and Evans, M. J.: Global inventory of nitrogen oxide emissions constrained by space-based observations of $\mathrm{NO}_{2}$ columns, J. Geophys. Res., 108, 4537, doi:10.1029/2003JD003453, 2003.

Massad, R.-S., Nemitz, E., and Sutton, M. A.: Review and parameterisation of bi-directional ammonia exchange between vegetation and the atmosphere, Atmos. Chem. Phys., 10, 10359-10386, doi:10.5194/acp-10-10359-2010, 2010a.

Massad, R.-S., Tuzet, A., Loubet, B., Perrier, A., and Cellier, P.: Model of stomatal ammonia compensation point (STAMP) in relation to the plant nitrogen and carbon metabolisms and environmental conditions, Ecol. Model., 221, 479-494, doi:10.1016/j.ecolmodel.2009.10.029, 2010b.

Matsumoto, K. and Uematsu, M.: Free amino acids in marine aerosols over the western North Pacific Ocean, Atmos. Environ., 39, 2163-2170, doi:10.1016/j.atmosenv.2004.12.022, 2005.

McFadyen, G. G. and Cape, J. N.: Peroxyacetyl nitrate in eastern Scotland, Sci. Total Environ., 337, 213-222, doi:10.1016/j.scitotenv.2004.06.016, 2005.

McKee, C. M.: Biogeochemical cycles of ammonia and dimethylsulphide in the marine environment, $\mathrm{PhD}$ thesis, University of East Anglia (UEA), Norwich, UK, 2001.

Medinets, S., Skiba, U., Rennenberg, H., and Butterbach-Bahl, K.: A review on soil NO transformation: Associated processes and possible physiological significance in organisms, Soil Biol. Biochem., 80, 92-117, doi:10.1016/j.soilbio.2014.09.025, 2015.

Melillo, J. M., Steudler, P. A., Aber, J. D., Newkirk, K., Lux, H., Bowles, F. P., Catricala, C., Magill, A., Ahrens, T., and Morrisseau, S.: Soil warming and carbon-cycle feedbacks to the climate system, Science, 298, 2173-2176, doi:10.1126/science.1074153, 2002.

Melillo, J. M., Butler, S., Johnson, J., Mohan, J., Steudler, P., Lux, H., Burrows, E., Bowles, F., Smith, R., Scott, L., Vario, C., Hill, T., Burton, A., Zhou, Y.-M., and Tang, J.: Soil warming, carbon-nitrogen interactions, and forest carbon budgets, P. Natl. Acad. Sci. USA, 108, 9508-9512, doi:10.1073/pnas.1018189108, 2011.

Meyer, M. W.: Absorption and release of ammonia from and to the atmosphere by plants, $\mathrm{PhD}$ thesis, University of Maryland, College Park, MD, USA, 63 pp., 1973.

Mikkelsen, T. N., Beier, C., Jonasson, S., Holmstrup, M., Schmidt, I. K., Ambus, P., Pilegaard, K., Michelsen, A., Albert, K., Andresen, L. C., Arndal, M. F., Bruun, N., Christensen, S., Dan- 
bæk, S., Gundersen, P., Jørgensen, P., Kongstad, J., Maraldo, K., Priemé, A., Riis-Nielsen, T., Ro-Poulsen, H., Stevnbak, K., Selsted, M. B., Sørensen, P., Larsen, K. S., Carter, M. S., Martinussen, T., Miglietta, F., and Sverdrup, H.: Experimental design of multifactor climate change experiments with elevated $\mathrm{CO}_{2}$, warming and drought - the CLIMAITE project, Funct. Ecol., 22, 185-195, doi:10.1111/j.1365-2435.2007.01362.x, 2008.

Miyazaki, K., Eskes, H. J., and Sudo, K.: Global $\mathrm{NO}_{\mathrm{x}}$ emission estimates derived from an assimilation of OMI tropospheric $\mathrm{NO}_{2}$ columns, Atmos. Chem. Phys., 12, 2263-2288, doi:10.5194/acp12-2263-2012, 2012.

Miyazaki, Y., Kawamura, K., and Sawano, M.: Size distributions of organic nitrogen and carbon in remote marine aerosols: evidence of marine biological origin based on their isotopic ratios, Geophys. Res. Lett., 37, L06803, doi:10.1029/2010GL042483, 2010.

Miyazaki, Y., Fu, P. Q., Ono, K., Tachibana, E., and Kawamura, K.: Seasonal cycles of water-soluble organic nitrogen aerosols in a deciduous broadleaf forest in northern Japan, J. Geophys. Res.Atmos., 119, 1440-1454, doi:10.1002/2013JD020713, 2014.

Monks, P. S., Granier, C., Fuzzi, S., Stohl, A., Williams, M. L., Akimoto, H., Amann, M., Baklanov, A., Baltensperger, U., Bey, I., Blake, N., Blake, R. S., Carslaw, K., Cooper, O. R., Dentener, F., Fowler, D., Fragkou, E., Frost, G. J., Generoso, S., Ginoux, P., Grewe, V., Guenther, A., Hansson, H. C., Henne, S., Hjorth, J., Hofzumahaus, A., Huntrieser, H., Isaksen, I. S. A., Jenkin, M. E., Kaiser, J., Kanakidou, M., Klimont, Z., Kulmala, M., Laj, P., Lawrence, M. G., Lee, J. D., Liousse, C., Maione, M., McFiggans, G., Metzger, A., Mieville, A., Moussiopoulos, N., Orlando, J. J., O’Dowd, C. D., Palmer, P. I., Parrish, D. D., Petzold, A., Platt, U., Poeschl, U., Prevot, A. S. H., Reeves, C. E., Reimann, S., Rudich, Y., Sellegri, K., Steinbrecher, R., Simpson, D., ten Brink, H., Theloke, J., van der Werf, G. R., Vautard, R., Vestreng, V., Vlachokostas, Ch., and von Glasow, R.: Atmospheric composition change - global and regional air quality, Atmos. Environ., 43, 5268-5350, doi:10.1016/j.atmosenv.2009.08.021, 2009.

Monks, P. S., Archibald, A. T., Colette, A., Cooper, O., Coyle, M., Derwent, R., Fowler, D., Granier, C., Law, K. S., Mills, G. E., Stevenson, D. S., Tarasova, O., Thouret, V., von Schneidemesser, E., Sommariva, R., Wild, O., and Williams, M. L.: Tropospheric ozone and its precursors from the urban to the global scale from air quality to short-lived climate forcer, Atmos. Chem. Phys., 15, 8889-8973, doi:10.5194/acp-15-8889-2015, 2015.

Monteith, J. L. and Unsworth, M. H.: Principles of environmental physics, 4th Edn., Elsevier, Amsterdam, 401 pp., 2013.

Montero-Martinez, G., Rinaldi, M., Gilardoni, S., Giulianelli, L., Paglione, M., Decesari, S., Fuzzi, S., and Facchini, M. C.: On the water-soluble organic nitrogen concentration and mass size distribution during the fog season in the Po Valley, Italy, Sci. Total Environ., 485-486, 103-109, doi:10.1016/j.scitotenv.2014.03.060, 2014.

Montoya, J. P., Holl, C. M., Zehr, J. P., Hansen, A., Villareal, T. A., and Capone, D. G.: High rates of $\mathrm{N}_{2}$ fixation by unicellular diazotrophs in the oligotrophic Pacific Ocean, Nature, 430, 1027-1032, doi:10.1038/nature02824, 2004.

Moore, C. M., Mills, M. M., Arrigo, K. R., Berman-Frank, I., Bopp, L., Boyd, P. W., Galbraith, E. D., Geider, R. J., Guieu, C., Jaccard, S. L., Jickells, T. D., La Roche, J., Lenton, T. M., Mahowald, N. M., Marañón, E., Marinov, I., Moore, J. K., Nakat- suka, T., Oschlies, A., Saito, M. A., Thingstad, T. F., Tsuda, A., and Ulloa, O.: Processes and patterns of oceanic nutrient limitation, Nat. Geosci., 6, 701-710, doi:10.1038/ngeo1765, 2013.

Moore, J. K. and Doney, S. C.: Iron availability limits the ocean nitrogen inventory stabilizing feedbacks between marine denitrification and nitrogen fixation, Global Biogeochem. Cy., 21, GB2001, doi:10.1029/2006GB002762, 2007.

Moore, J. K., Doney, S. C., Glover, D. M., and Fung, I. Y.: Iron cycling and nutrient-limitation patterns in surface waters of the world ocean, Deep-Sea Res. Pt. II, 49, 463-507, doi:10.1016/S0967-0645(01)00109-6, 2002.

Moore, J. K., Doney, S. C., Lindsay, K., Mahowald, N., and Michaels, A. F.: Nitrogen fixation amplifies the ocean biogeochemical response to decadal timescale variations in mineral dust deposition, Tellus B, 58, 560-572, doi:10.1111/j.16000889.2006.00209.x, 2006.

Mulholland, M. R., Bernhardt, P. W., Heil, C. A., Bronk, D. A., and O'Neil, J. M.: Nitrogen fixation and release of fixed nitrogen by Trichodesmium spp. in the Gulf of Mexico, Limnol. Oceanogr 51, 1762-1776, doi:10.4319/lo.2006.51.4.1762, 2006.

Müller, C., Iinuma, Y., Karstensen, J., van Pinxteren, D., Lehmann, S., Gnauk, T., and Herrmann, H.: Seasonal variation of aliphatic amines in marine sub-micrometer particles at the Cape Verde islands, Atmos. Chem. Phys., 9, 9587-9597, doi:10.5194/acp-99587-2009, 2009.

Murphy, S. M., Sorooshian, A., Kroll, J. H., Ng, N. L., Chhabra, P., Tong, C., Surratt, J. D., Knipping, E., Flagan, R. C., and Seinfeld, J. H.: Secondary aerosol formation from atmospheric reactions of aliphatic amines, Atmos. Chem. Phys., 7, 2313-2337, doi:10.5194/acp-7-2313-2007, 2007.

Neff, J. C., Holland, E. A., Dentener, F. J., McDowell, W. H., and Russell, K. M.: The origin, composition and rates of organic nitrogen deposition: a missing piece of the nitrogen cycle?, Biogeochemistry, 57/58, 99-136, doi:10.1023/A:1015791622742, 2002.

Neirynck, J., Kowalski, A. S., Carrara, A., Genouw, G., Berghmans, P., and Ceulemans, R.: Fluxes of oxidised and reduced nitrogen above a mixed coniferous forest exposed to various nitrogen emission sources, Environ. Pollut., 149, 31-43, doi:10.1016/j.envpol.2006.12.029, 2007.

Nemitz, E., Sutton, M. A., Wyers, G. P., Otjes, R. P., Schjoerring, J. K., Gallagher, M. W., Parrington, J., Fowler, D., and Choularton, T. W.: Surface/atmosphere exchange and chemical interaction of gases and aerosols over oilseed rape. Agr. Forest Meteorol., 105, 427-445, doi:10.1016/S0168-1923(00)00207-0, 2000.

Nemitz, E., Dorsey, J. R., Flynn, M. J., Gallagher, M. W., Hensen, A., Erisman, J.-W., Owen, S. M., Dämmgen, U., and Sutton, M. A.: Aerosol fluxes and particle growth above managed grassland, Biogeosciences, 6, 1627-1645, doi:10.5194/bg-6-16272009, 2009.

Nemitz, E., Langford, B., Ryder, J., Vieno, M., and Sutton, M. A.: Ammonium nitrate deposition modeling - accounting for evaporation during the deposition process, Presentation OP06-6, International Aerosol Conference, Busan, South Korea, 28 August-2 September 2014.

Nguyen, T. B., Lee, P. B., Updyke, K. M., Bones, D. L., Laskin, J., Laskin, A., and Nizkorodov, S. A.: Formation of nitrogenand sulfur-containing light-absorbing compounds accelerated by 
evaporation of water from secondary organic aerosols, J. Geophys. Res., 117, D01207, doi:10.1029/2011JD016944, 2012.

Noble, A. E., Lamborg, C. H., Ohnemus, D. C., Lam, P. J., Goepfert, T. J., Measures, C. I., Frame, C. H., Casciotti, K. L., Ditullio, G. R., Jennings, J., and Saito, M. A.: Basin-scale inputs of cobalt, iron, and manganese from the Benguela-Angola front to the South Atlantic Ocean, Limnol. Oceanogr., 57, 989-1010, doi:10.4319/lo.2012.57.4.0989, 2012.

Norby, R. J., Warren, J. M., Iversen, C. M., Medlyn, B. E., and McMurtrie, R. E.: $\mathrm{CO}_{2}$ enhancement of forest productivity constrained by limited nitrogen availability, P. Natl. Acad. Sci. USA, 107, 19368-19373, doi:10.1073/pnas.1006463107, 2010.

Nozière, B., Dziedzic, P., and Córdova, A.: Formation of secondary light-absorbing "fulvic-like" oligomers: A common process in aqueous and ionic atmospheric particles? Geophys. Res. Lett., 34, L21812, doi:10.1029/2007GL031300, 2007.

Nozière, B., Dziedzic, P., and Córdova, A.: Products and kinetics of the liquid-phase reaction of glyoxal catalyzed by ammonium ions $\left(\mathrm{NH}_{4}^{+}\right)$, J. Phys. Chem., 113, 231-237, doi:10.1021/jp8078293, 2009.

O’Brien, R. E., Laskin, A., Laskin, J., Liu, S., Weber, R., Russell, L. M., and Goldstein, A. H.: Molecular characterization of organic aerosol using nanospray desorption/electrospray ionization mass spectrometry: CalNex 2010 field study, Atmos. Environ., 68, 265-272, doi:10.1016/j.atmosenv.2012.11.056, 2013.

Oswald, R., Behrendt, T., Ermel, M., Wu, D., Su, H., Cheng, Y., Breuninger, C., Moravek, A., Mougin, E., Delon, C., Loubet, B., Pommerening-Röser, A., Sörgel, M., Pöschl, U., Hoffmann, T., Andreae, M. O., Meixner, F. X., and Trebs, I.: HONO emissions from soil bacteria as a major source of atmospheric reactive nitrogen, Science, 341, 1233-1235, doi:10.1126/science.1242266, 2013.

Paerl, H. W., Crocker, K. M., and Prufert, L. E.: Limitation of $\mathrm{N}_{2}$ fixation in coastal marine waters: Relative importance of molybdenum, iron, phosphorus, and organic matter availability, Limnol. Oceanogr., 32, 525-536, doi:10.4319/lo.1987.32.3.0525, 1987.

Palmroth, S., Oren, R., McCarthy, H. R., Johnsen, K. H., Finzi, A. C., Butnor, J. R., Ryan, M. G., and Schlese, U.: Aboveground sink strength in forests controls the allocation of carbon below ground and its $\left[\mathrm{CO}_{2}\right]$-induced enhancement, P. Natl. Acad. Sci. USA., 103, 19362-19367, doi:10.1073/pnas.0609492103, 2006.

Park, S., Croteau, P., Boering, K. A., Etheridge, D. M., Ferretti, D., Fraser, P. J., Kim, K.-R., Krummel, P. B., Langenfelds, R. L., van Ommen, T. D., Steele, L. P., and Trudinger, C. M.: Trends and seasonal cycles in the isotopic composition of nitrous oxide since 1940, Nat. Geosci., 5, 261-265, doi:10.1038/ngeo1421, 2012.

Parrish, D. D., Dunlea, E. J., Atlas, E. L., Schauffler, S., Donnelly, S., Stroud, V., Goldstein, A. H., Millet, D. B., McKay, M., Jaffe, D. A., Price, H. U., Hess, P. G., Flocke, F., and Roberts, J. M.: Changes in the photochemical environment of the temperate North Pacific troposphere in response to increased Asian emissions, J. Geophys. Res.-Atmos., 109, D23S18, doi:10.1029/2004JD004978, 2004.

Paulsen, D. M., Paerl, H. W., and Bishop, P. E.: Evidence that molybdenum-dependent nitrogen fixation is not limited by high sulfate concentrations in marine environments, Limnol. Oceanogr., 36, 1325-1334, doi:10.4319/lo.1991.36.7.1325, 1991.
Paumen, M. L., de Voogt, P., van Gestel, C. A. M., and Kraak, M. H. S.: Comparative chronic toxicity of homo- and heterocyclic aromatic compounds to benthic and terrestrial invertebrates: generalizations and exceptions, Sci. Total Environ., 407, 4605-4609, doi:10.1016/j.scitotenv.2009.04.039, 2009.

Peierls, B. L. and Paerl, H. W.: Bioavailability of atmospheric organic nitrogen deposition to coastal phytoplankton, Limnol. Oceanogr., 42, 1819-1823, doi:10.4319/lo.1997.42.8.1819, 1997.

Pilegaard, K.: Processes regulating nitric oxide emissions from soils, Philos. T. Roy. Soc. B, 368, 1621, doi:10.1098/rstb.2013.0126, 2013.

Pinay, G., Gumiero, B., Tabacchi, E., Gimenez, O., Tabacchi-Planty, A. M., Hefting, M. M., Burt, T. P., Black, V. A., Nilsson, C., Iordache, V., Bureau, F., Vought, L., Petts, G. E., and Décamps, H.: Patterns of denitrification rates in European alluvial soils under various hydrological regimes, Freshwater Biol., 52, 252-266, doi:10.1111/j.1365-2427.2006.01680.x, 2007.

Porada, P., Weber, B., Elbert, W. Pöschl, U., and Kleidon, A.: Estimating impacts of lichens and bryophytes on global biogeochemical cycles, Global Biogeochem. Cy., 28, 71-85, doi:10.1002/2013GB004705, 2014.

Powelson, M. H., Espelien, B. M., Hawkins, L. N., Galloway, M. M., and De Haan, D. O.: Brown carbon formation by aqueous-phase carbonyl compound reactions with amines and ammonium sulfate, Environ. Sci. Technol., 48, 985-993, doi:10.1021/es4038325, 2014.

Prather, M. J. and Ehhalt, D.: Atmospheric chemistry and greenhouse gases, in: Climate Change 2001: The scientific basis. Contribution of Working Group I to the Third Assessment Report of the Intergovernmental Panel on Climate Change, edited by: Houghton, J. T., Ding, Y., Griggs, D. J., Noguer, M., van der Linden, P. J., Dai, X., Maskell, K., and Johnson, C. A., Intergovernmental Panel on Climate Change (IPCC), Cambridge University Press, Cambridge, United Kingdom and New York, NY, USA, Chapter 4, 239-287, 2001.

Prospero, J. M. and Lamb, P. J.: African droughts and dust transport to the Caribbean: Climate change implications, Science, 302, 1024-1027, doi:10.1126/science.1089915, 2003.

Pye, H. O. T., Liao, H., Wu, S., Mickley, L. J., Jacob, D. J., Henze, D. K., and Seinfeld, J. H.: Effect of changes in climate and emissions on future sulfate-nitrate-ammonium aerosol levels in the United States, J. Geophys. Res., 114, D01205, doi:10.1029/2008JD010701, 2009.

Rastogi, N., Zhang, X. L., Edgerton, E. S., Ingall, E., and Weber, R. J.: Filterable water-soluble organic nitrogen in fine particles over the southeastern USA during summer, Atmos. Environ., 45, 6040-6047, doi:10.1016/j.atmosenv.2011.07.045, 2011.

Ravishankara, A. R., Daniel, J. S., and Portmann, R. W.: Nitrous oxide $\left(\mathrm{N}_{2} \mathrm{O}\right)$ : the dominant ozone-depleting substance emitted in the 21st century, Science, 326, 5949, doi:10.1126/science.1176985, 2009.

Reeve, N., and Toumi, R.: Lightning activity as an indicator of climate change, Q. J. Roy. Meteor. Soc., 125, 893-903, doi:10.1002/qj.49712555507, 1999.

Riddick, S. N., Dragosits, U., Blackall, T. D., Daunt, F., Wanless, S., and Sutton, M. A.: The global distribution of ammonia emissions from seabird colonies, Atmos. Environ., 55, 319-327, doi:10.1016/j.atmosenv.2012.02.052, 2012. 
Riedo, M., Milford, C., Schmid, M., and Sutton, M. A.: Coupling soil-plant-atmosphere exchange of ammonia with ecosystem functioning in grasslands, Ecol. Model., 158, 83-110, doi:10.1016/S0304-3800(02)00169-2, 2002.

Rincon, A. G., Calvo, A. I., Dietzel, M., and Kalberer, M.: Seasonal differences of urban organic aerosol composition - an ultra-high resolution mass spectrometry study, Environ. Chem., 9, 298-319, doi:10.1071/EN12016, 2012.

Roberts, J. M.: The atmospheric chemistry of organic nitrates, Atmos. Environ. A-Gen., 24, 243-287, doi:10.1016/09601686(90)90108-Y, 1990.

Romps, D. M., Seeley, J. T., Vollaro, D., and Molinari, J.: Projected increase in lightning strikes in the United States due to global warming, Science, 346 851-853, doi:10.1126/science.1259100, 2014.

Rosa, S. M., Kraemer, F. B., Soria, M. A., Guerrero, L. D., Morrás, H. J. M., Figuerola, E. L. M., and Erijman, L.: The influence of soil properties on denitrifying bacterial communities and denitrification potential in no-till production farms under contrasting management in the Argentinean Pampas, Appl. Soil Ecol., 75, 172-180, doi:10.1016/j.apsoil.2013.11.012, 2014.

Russell, K. M., Keene, W. C., Maben, J. R., Galloway, J. N., and Moody, J. L.: Phase partitioning and dry deposition of atmospheric nitrogen at the mid-Atlantic US coast, J. Geophys. Res., 108, 4656, doi:10.1029/2003JD003736, 2003.

Rustad, L. E., Campbell, J. L., Marion, G. M., Norby, R. J., Mitchell, M. J., Hartley, A. E., Cornelissen, J. H. C., and Gurevitch, J.: A meta-analysis of the response of soil respiration, net nitrogen mineralization, and aboveground plant growth to experimental ecosystem warming, Oecologia, 126, 543-562, doi:10.1007/s004420000544, 2001.

Ryder, J.: Emission, deposition and chemical conversion of atmospheric trace substances in and above vegetation canopies, $\mathrm{PhD}$ thesis, University of Manchester, Manchester, 2010.

Sarmiento, J. L., Slater, R., Barber, R., Bopp, L., Doney, S. C., Hirst, A. C., Kleypas, J., Matear, R., Mikolajewicz, U., Monfray, P., Soldatov, V., Spall, S. A., and Stouffer, R.: Response of ocean ecosystems to climate warming, Global Biogeochem. Cy., 18, GB3003, doi:10.1029/2003GB002134, 2004.

Saxena, P. and Hildemann, L. M.: Water-soluble organics in atmospheric particles: A critical review of the literature and application of thermodynamics to identify candidate compounds, J. Atmos. Chem., 24, 57-109, doi:10.1007/BF00053823, 1996.

Scalabrin, E., Zangrando, R., Barbaro, E., Kehrwald, N. M., Gabrieli, J., Barbante, C., and Gambaro, A.: Amino acids in Arctic aerosols, Atmos. Chem. Phys., 12, 10453-10463, doi:10.5194/acp-12-10453-2012, 2012.

Schreiber, F., Wunderlin, P., Udert, K. M., and Wells, G. F.: Nitric oxide and nitrous oxide turnover in natural and engineered microbial communities: biological pathways, chemical reactions, and novel technologies, Front. Microbiol., 3, 372, doi:10.3389/fmicb.2012.00372, 2012.

Schumann, U. and Huntrieser, H.: The global lightning-induced nitrogen oxides source, Atmos. Chem. Phys., 7, 3823-3907, doi:10.5194/acp-7-3823-2007, 2007.

Seinfield, J. H. and Pandis, S. N.: Atmospheric physics and chemistry, 1st Edn., John Wiley \& Sons, 1998.

Seitzinger, S., Harrison, J. A., Bohlkem J. K., Bouwman, A. F., Lowrance, R., Peterson, B., Tobias, C., and Van
Drecht, G.: Denitrification across landscapes and waterscapes: a synthesis, Ecol. Appl., 16, 2064-2090, doi:10.1890/10510761(2006)016[2064:DALAWA]2.0.CO;2, 2006.

Seitzinger, S. P. and Sanders, R. W.: Atmospheric inputs of dissolved organic nitrogen stimulate estuarine bacteria and phytoplankton, Limnol. Oceanogr., 44, 721-730, doi:10.4319/lo.1999.44.3.0721, 1999.

Shapiro, E. L., Szprengiel, J., Sareen, N., Jen, C. N., Giordano, M. R., and McNeill, V. F.: Light-absorbing secondary organic material formed by glyoxal in aqueous aerosol mimics, Atmos. Chem. Phys., 9, 2289-2300, doi:10.5194/acp-9-2289-2009, 2009.

Sharp, R. G. and Davies, W. J.: Variability among species in the apoplastic $\mathrm{pH}$ signalling response to drying soils, J. Exp. Bot., 60, 4363-4370, doi:10.1093/jxb/erp273, 2009.

Shen, J., Cui, Z., Miao, Y., Mi, G., Zhang, H., Fan, M., Zhang, C., Jiang, R., Zhang, W., Li, H., Chen, X., Li, X., and Zhang, F.: Transforming agriculture in China: From solely high yield to both high yield and high resource use efficiency, Global Food Security, 2, 1-8, doi:10.1016/j.gfs.2012.12.004, 2013.

Shi, D., Xu, Y., Hopkinson, B. M., and Morel, F. M. M.: Effect of ocean acidification on iron availability to marine phytoplankton, Science, 327, 676-679, doi:10.1126/science.1183517, 2010.

Shi, J. H., Han, J., Fan, D. G., Qi, J. H., and Gao, H. W.: Contribution of water soluble organic nitrogen to total nitrogen in atmospheric aerosols in Qingdao, Huanjing Kexue, 32, 1-8, 2011.

Simpson, D., Benedictow, A., Berge, H., Bergström, R., Emberson, L. D., Fagerli, H., Flechard, C. R., Hayman, G. D., Gauss, M., Jonson, J. E., Jenkin, M. E., Nyíri, A., Richter, C., Semeena, V. S., Tsyro, S., Tuovinen, J.-P., Valdebenito, Á., and Wind, P.: The EMEP MSC-W chemical transport model - technical description, Atmos. Chem. Phys., 12, 7825-7865, doi:10.5194/acp-127825-2012, 2012.

Simpson, D., Andersson, C., Christensen, J. H., Engardt, M., Geels, C., Nyiri, A., Posch, M., Soares, J., Sofiev, M., Wind, P., and Langner, J.: Impacts of climate and emission changes on nitrogen deposition in Europe: a multi-model study, Atmos. Chem. Phys., 14, 6995-7017, doi:10.5194/acp-14-6995-2014, 2014.

Singh, B. K., Bardgett, R. D., Smith, P., and Reay, D. S.: Microorganisms and climate change: terrestrial feedbacks and mitigation options, Nat. Rev. Microbiol., 8, 779-790, doi:10.1038/nrmicro2439, 2010.

Singh, H. B. and Hanst, P. L.: Peroxyacetyl nitrate (PAN) in the unpolluted atmosphere: An important reservoir for nitrogen oxides, Geophys. Res. Lett., 8, 941-944, doi:10.1029/GL008i008p00941, 1981.

Sitch, S., Cox, P. M., Collins, W. J., and Huntingford, C.: Indirect radiative forcing of climate change through ozone effects on the land-carbon sink, Nature, 448, 791-795, doi:10.1038/nature06059, 2007.

Skiba, U., van Dijk, S., and Ball, B. C.: The influence of tillage on $\mathrm{NO}$ and $\mathrm{N}_{2} \mathrm{O}$ fluxes under spring and winter barley, Soil Use Manage., 18, 340-345, doi:10.1111/j.14752743.2002.tb00250.x, 2002.

Smil, V.: Nitrogen in crop production: An account of global flows, Global Biogeochem. Cy., 13, 647-662, doi:10.1029/1999GB900015, 1999.

Smith, J. N., Barsanti, K. C., Friedli, H. R., Ehn, M., Kulmala, M., Collins, D. R., Scheckman, J. H., Wiliams, B. J., and McMurry, P. H.: Observations of aminium salts in atmospheric nanoparticles 
and possible climatic implications, P. Natl. Acad. Sci. USA, 107, 6634-6639, doi:10.1073/pnas.0912127107, 2010.

Sokolov, A. P., Kicklighter, D. W., Melillo, J. M., Felzer, B. S., Schlosser, C. A., and Cronin, T. W.: Consequences of considering carbon-nitrogen interactions on the feedbacks between climate and the terrestrial carbon cycle. J. Climate, 21, 3776-3796, doi:10.1175/2008JCLI2038.1, 2008.

Spokes, L. J., Yeatman, S. G., Cornell, S. E., and Jickells, T. D.: Nitrogen deposition to the eastern Atlantic Ocean. The importance of south-easterly flow, Tellus B, 52, 37-49, doi:10.1034/j.16000889.2000.00062.x, 2000.

Srinivas, B., Sarin, N. M., and Sarma, V. V. S. S.: Atmospheric dry deposition of inorganic and organic nitrogen to the Bay of Bengal: Impact of continental outflow, Mar. Chem., 127, 170-179, doi:10.1016/j.marchem.2011.09.002, 2011.

Staal, M., Meysman, F. J. R., and Stal, L. J.: Temperature excludes $\mathrm{N}_{2}$-fixing heterocystous cyanobacteria in the tropical oceans, Nature, 425, 504-507, doi:10.1038/nature01999, 2003.

Steadman, C. E., Stevenson, D. S., Fowler, D., Heal, M., and Sutton, M.: Ammonia emissions from the ocean in the 21 st century the effect of rising temperatures and $\mathrm{CO}_{2}$ levels on the exchange of ammonia between the atmosphere and oceans, in preparation, 2015 .

Stevenson, D. S., Dentener, F. J., Schultz, M. G., Ellingsen, K., van Noije, T. P. C., Wild, O., Zeng, G., Amann, M., Atherton, C. S., Bell, N., Bergmann, D. J., Bey, I., Butler, T., Cofala, J., Collins, W. J., Derwent, R. G., Doherty, R. M., Drevet, J., Eskes, H. J., Fiore, A. M., Gauss, M., Hauglustaine, D. A., Horowitz, L. W., Isaksen, I. S. A., Krol, M. C., Lamarque, J.-F., Lawrence, M. G., Montanaro, V., Müller, J.-F., Pitari, G., Prather, M. J., Pyle, J. A., Rast, S., Rodriguez, J. M., Sanderson, M. G., Savage, N. H., Shindell, D. T., Strahan, S. E., Sudo, K., and Szopa, S.: Multimodel ensemble simulations of present-day and near-future tripospheric ozone, J. Geophys. Res, 111, D08301, doi:10.1029/2005JD006338, 2006.

Stevenson, F. J., Harrison, R. M., Wetselaar, R., and Leeper, R. A.: Nitrosation of soil organic matter: III. Nature of gases produced by reaction of nitrite with lignins, humic substances, and phenolic constituents under neutral and slightly acidic conditions, Soil Sci. Soc. Am. J., 34, 430-435, doi:10.2136/sssaj1970.03615995003400030024x, 1970.

Stocker, B. D., Roth, R., Joos, F., Spahni, R., Steinacher, M., Zaehle, S., Bouwman, L., Xu-Ri, and Prentice, I. C.: Multiple greenhouse-gas feedbacks from the land biosphere under future climate change scenarios, Nat. Clim. Change, 3, 666-672, doi:10.1038/nclimate1864, 2013.

Su, H., Cheng, Y., Oswald, R., Behrendt, T., Trebs, I., Meixner, F. X., Andreae, M. O., Cheng, P., Zhang, Y., and Pöschl, U.: Soil Nitrite as a Source of Atmospheric HONO and OH Radicals, Science, 333, 1616-1618, doi:10.1126/science.1207687, 2011.

Sun, Y. L., Wang, Z. F., Fu, P. Q., Yang, T., Jiang, Q., Dong, H. B., Li, J., and Jia, J. J.: Aerosol composition, sources and processes during wintertime in Beijing, China, Atmos. Chem. Phys., 13, 4577-4592, doi:10.5194/acp-13-4577-2013, 2013.

Sutton, M. A., Schjørring, J. K., Wyers, G. P., Duyzer, J. H., Ineson, P., and Powlson, D. S.: Plant-atmosphere exchange of ammonia, Philos. T. Roy. Soc. A, 351, 261-275, doi:10.1098/rsta.1995.0033, 1995.
Sutton, M. A., Burkhardt, J. K., Guerin, D., Nemitz, E., and Fowler, D.: Development of resistance models to describe measurements of bi-directional ammonia surface atmosphere exchange, Atmos. Environ., 32, 473-480, doi:10.1016/S1352-2310(97)00164-7, 1998.

Sutton, M. A., Nemitz, E., Milford, C., Campbell, C., Erisman, J. W., Hensen, A., Cellier, P., David, M., Loubet, B., Personne, E., Schjoerring, J. K., Mattsson, M., Dorsey, J. R., Gallagher, M. W., Horvath, L., Weidinger, T., Meszaros, R., Dämmgen, U., Neftel, A., Herrmann, B., Lehman, B. E., Flechard, C., and Burkhardt, J.: Dynamics of ammonia exchange with cut grassland: synthesis of results and conclusions of the GRAMINAE Integrated Experiment, Biogeosciences, 6, 2907-2934, doi:10.5194/bg-6-29072009, 2009.

Sutton, M. A., Howard, C. M., Erisman, J. W., Billen, G., Bleeker, A. Grennfelt, P., van Grinsven, H., and Grizzetti, B. (Eds.): The European Nitrogen Assessment: Sources, effects and policy perspectives, Cambridge University Press, 2011.

Sutton, M. A., Bleeker, A., Howard, C. M., Bekunda, M., Grizzetti, B., de Vries, W., van Grinsven, H. J. M., Abrol, Y. P., Adhya, T. K., Billen, G., Davidson, E. A., Datta, A., Diaz, R., Erisman, J. W., Liu, X. J., Oenema, O., Palm, C., Raghuram, N., Reis, S., Scholz, R. W., Sims, T., Westhoek, H., and Zhang F. S.: Our Nutrient World: The challenge to produce more food and energy with less pollution, Global Overview of Nutrient Management, Centre for Ecology \& Hydrology, Edinburgh on behalf of the Global Partnership on Nutrient Management and the International Nitrogen Initiative, 114 pp., 2013a.

Sutton, M. A., Reis, S., Riddick, S. N., Dragosits, U., Nemitz, E., Theobald, M. R., Tang, Y. S., Braban, C. F., Vieno, M., Dore, A. J., Mitchell, R. F., Wanless, S., Daunt, F., Fowler, D., Blackall, T. D., Milford, C., Flechard, C. R., Loubet, B., Massad, R. S., Cellier, P., Personne, E., Coheur, P. F., Clarisse, L., Van Damme, M., Ngadi, Y., Clerbaux, C., Skjøth, C. A., Geels, C., Hertel, O., Wichink Kruit, R. J., Pinder, R. W., Bash, J. O., Walker, J. T., Simpson, D., Horváth, L., Misselbrook, T. H., Bleeker, A., Dentener, F., and de Vries, W.: Towards a climate-dependent paradigm of ammonia emission and deposition, Philos. T. Roy. Soc. B, 368, 1621, doi:10.1098/rstb.2013.0166, 2013 b.

Syakila, A. and Kroeze, C.: The global nitrous oxide budget revisited, Greenhouse Gas Measurement Management, 1, 17-26, doi:10.3763/ghgmm.2010.0007, 2011.

Thomas, R.: Measurement of speciated aerosol fluxes, $\mathrm{PhD}$ thesis, University of Manchester, Manchester, 2007.

Thornton, P. E., Doney, S. C., Lindsay, K., Moore, J. K., Mahowald, N., Randerson, J. T., Fung, I., Lamarque, J.-F., Feddema, J. J., and Lee, Y.-H.: Carbon-nitrogen interactions regulate climate-carbon cycle feedbacks: results from an atmosphereocean general circulation model, Biogeosciences, 6, 2099-2120, doi:10.5194/bg-6-2099-2009, 2009.

Timperley, M. H., Vigor-Brown, R. J., Kawashima, M., and Ishigami, M.: Organic nitrogen compounds in atmospheric precipitation: their chemistry and availability to phytoplankton, Can J. Fish. Aquat. Sci., 42, 1171-1177, doi:10.1139/f85-145, 1985.

Trost, B., Prochnow, A., Drastig, K., Meyer-Aurich, A., Ellmer, F., and Baumecker, M.: Irrigation, soil organic carbon and $\mathrm{N}_{2} \mathrm{O}$ emissions. A review, Agron. Sustain. Dev., 33, 733-749, doi:10.1007/s13593-013-0134-0, 2013. 
Tuomi, R., Haigh, J. D., and Law, K.: A tropospheric ozonelightning climate feedback, Geophys. Res. Lett., 23, 1037-1040, doi:10.1029/96GL00944, 1996.

Tuovinen, J.-P., Hakola, H., Karlsson, P. E., and Simpson, D.: Air pollution risks to northern European forests in a changing climate, in: Air pollution and global Challenges. Understanding and perspectives from forest research, edited by: Matyssek, R., Clarke, N., Cudlin, P., Mikkelsen, T., Tuovinen, J.-P., Wieser, G., and Paoletti, E., Elsevier, Oxford, UK, Chapter 5, 77-99, 2013.

Van Damme, M., Clarisse, L., Heald, C. L., Hurtmans, D., Ngadi, Y., Clerbaux, C., Dolman, A. J., Erisman, J. W., and Coheur, P. F.: Global distributions, time series and error characterization of atmospheric ammonia (NH3) from IASI satellite observations, Atmos. Chem. Phys., 14, 2905-2922, doi:10.5194/acp-14-29052014, 2014.

van Groenigen, K. J., Osenberg, C. W., and Hungate, B. A.: Increased soil emissions of potent greenhouse gases under increased atmospheric $\mathrm{CO}_{2}$, Nature, 475, 214-216, doi:10.1038/nature10176, 2011.

van Vuuren, D. P., Bouwman, A. F., Smith, S. J., and Dentener, F.: Global projections for anthropogenic reactive nitrogen emissions to the atmosphere: an assessment of scenarios in the scientific literature, Curr. Opin. Environ. Sustain., 3, 359-369, doi:10.1016/j.cosust.2011.08.014, 2011a.

van Vuuren, D. P., Edmonds, J., Kainuma, M., Riahi, K., Thomson, A., Hibbard, K., Hurtt, G. C., Kram, T., Krey, V., Lamarque, J.F., Matsui, T., Meinshausen, M., Nakicenovic, N., Smith, S. J., and Rose, S. K.: The representative concentration pathways: an overview, Climatic Change, 109, 5-31, doi:10.1007/s10584-0110148-z, 2011b.

Velikova, V., Pinelli, P., Pasqualini, S., Reale, L., Ferranti, F., and Loreto, F.: Isoprene decreases the concentration of nitric oxide in leaves exposed to elevated ozone, New Phytol., 166, 419-426, doi:10.1111/j.1469-8137.2005.01409.x, 2005.

Vieno, M., Heal, M. R., Hallsworth, S., Famulari, D., Doherty, R. M., Dore, A. J., Tang, Y. S., Braban, C. F., Leaver, D., Sutton, M. A., and Reis, S.: The role of long-range transport and domestic emissions in determining atmospheric secondary inorganic particle concentrations across the UK, Atmos. Chem. Phys., 14, 8435-8447, doi:10.5194/acp-14-8435-2014, 2014.

Vile, M. A., Wieder, R. K., Živković, T., Scott, K. D., Vitt, D. H., Hartsock, J. A., Iosue, C. L., Quinn, J. C., Petrix, M., Fillingim, H. M., Popma, J. M. A., Dynarski, K. A., Jackman, T. R., Albright, C. M., and Wykoff, D. D.: $\mathrm{N}_{2}$-fixation by methanotrophs sustains carbon and nitrogen accumulation in pristine peatlands, Biogeochemistry, 121, 317-328, doi:10.1007/s10533-014-00196, 2014.

Violaki, K. and Mihalopoulos, N.: Water-soluble organic nitrogen (WSON) in size-segregated atmospheric particles over the Eastern Mediterranean, Atmos. Environ., 44, 4339-4345, doi:10.1016/j.atmosenv.2010.07.056, 2010.

Violaki, K. and Mihalopoulos, N.: Urea: An important piece of Water Soluble Organic Nitrogen (WSON) over the Eastern Mediterranean, Sci. Total Environ., 409, 4796-4801, doi:10.1016/j.scitotenv.2011.07.060, 2011.

Vitousek, P. M., Cassman, K., Cleveland, C., Crews, T., Field, C. B., Grimm, N. B., Howarth, R. W., Marino, R., Martinelli, L., Rastetter, E. B., and Sprent, J. I.: Towards an ecological under- standing of biological nitrogen fixation, Biogeochemistry, 57/58, 1-45, doi:10.1023/A:1015798428743, 2002.

Vitousek, P. M., Menge, D. N., Reed, S. C., and Cleveland, C. C.: Biological nitrogen fixation: rates, patterns and ecological controls in terrestrial ecosystems, Philos. T. Roy. Soc. B, 368, 1621, doi:10.1098/rstb.2013.0119, 2013.

Voss, M., Bange, H. W., Dippner, J. W., Middelburg, J. J., Montoya, J. P., and Ward, B.: The marine nitrogen cycle: recent discoveries, uncertainties and the potential relevance of climate change, Philos. T. Roy. Soc. B, 368, 1621, doi:10.1098/rstb.2013.0121, 2013.

Walker, J. T., Jones, M. R., Bash, J. O., Myles, L., Meyers, T., Schwede, D., Herrick, J., Nemitz, E., and Robarge, W.: Processes of ammonia air-surface exchange in a fertilized Zea mays canopy, Biogeosciences, 10, 981-998, doi:10.5194/bg-10-9812013, 2013.

Wang, Y., Jacob, D. J., and Logan, J. A.: Global simulation of tropospheric $\mathrm{O}_{3}-\mathrm{NO}_{x}$-hydrocarbon chemistry: 1. Model formulation, J. Geophys. Res.-Atmos., 103, 10713-10725, doi:10.1029/98JD00158, 1998.

Westhoek, H., Lesschen, J. P., Rood, T., Wagner, S., De Marco, A., Murphy-Bokern, D., Leip, A., van Grinsven, H., Sutton, M. A., and Oenema, O.: Food choices, health and environment: Effects of cutting Europe's meat and dairy intake, Global Environ. Chan., 26, 196-205, doi:10.1016/j.gloenvcha.2014.02.004, 2014.

Wichink Kruit, R. J., Schaap, M., Sauter, F. J., van Zanten, M. C., and van Pul, W. A. J.: Modeling the distribution of ammonia across Europe including bi-directional surface-atmosphere exchange, Biogeosciences, 9, 5261-5277, doi:10.5194/bg-9-52612012, 2012.

Wilkinson, S. and Davies, W. J.: Manipulation of the apoplastic $\mathrm{pH}$ of intact plants mimics stomatal and growth responses to water availability and microclimatic variation, J. Exp. Bot., 59, 619631, doi:10.1093/jxb/erm338, 2008.

Williams, E.: Lightning and climate: A review, Atmos. Res., 76, 272-287, doi:10.1016/j.atmosres.2004.11.014, 2005.

Winiwarter, W., Erisman, J. W., Galloway, J. N., Klimont, Z., and Sutton, M. A.: Estimating environmentally relevant fixed nitrogen demand in the 21st century, Climatic Change, 120, 889-901, doi:10.1007/s10584-013-0834-0, 2013.

Wittig, V. E., Ainsworth, E. A., and Long, S. P.: To what extent do current and projected increases in surface ozone affect photosynthesis and stomatal conductance of trees? A meta-analytic review of the last 3 decades of experiments, Plant Cell Environ., 30, 1150-1162, doi:10.1111/j.1365-3040.2007.01717.x, 2007.

Wolff, V., Trebs, I., Ammann, C., Spierig, C., Flechard, C., Neftel, A., and Meixner, F. X.: Concentrations and fluxes of soluble reactive nitrogen compounds over an intensively managed grassland site, Geophys. Res. Abstr., 9, 02906, EGU2007-A-02906, 2007.

Wolff, V., Meixner, F. X., and Trebs, I.: Mixing ratios and exchange processes of the ammonia-nitric acid-ammonium nitrate triad above a spruce forest canopy, in: Proceedings of "Earth observations for land-atmosphere interaction science", edited by: Lacoste-Francid, H., Frascati, Italy, ESA SP-688, European Space Agency, Noordwijk, 2011.

Wolfe, G. M., Thornton, J. A., Yatavelli, R. L. N., McKay, M., Goldstein, A. H., LaFranchi, B., Min, K.-E., and Cohen, R. C.: Eddy 
covariance fluxes of acyl peroxy nitrates (PAN, PPN and MPAN) above a Ponderosa pine forest, Atmos. Chem. Phys., 9, 615-634, doi:10.5194/acp-9-615-2009, 2009.

$\mathrm{Xu}-\mathrm{Ri}$ and Prentice, I. C.: Terrestrial nitrogen cycle simulation with a dynamic global vegetation model, Global Change Biol., 14, 1745-1764, doi:10.1111/j.1365-2486.2008.01625.x, 2008.

Yienger, J. J. and Levy II, H.: Empirical model of global soilbiogenic $\mathrm{NO}_{x}$ emissions, J. Geophys. Res., 100, 11447-11464, doi:10.1029/95JD00370, 1995.

Zaehle, S.: Terrestrial nitrogen-carbon cycle interactions at the global scale, Philos. T. Roy. Soc. B, 368, 1621, doi:10.1098/rstb.2013.0125, 2013.

Zaehle, S. and Dalmonech, D.: Carbon-nitrogen interactions on land at global scales: current understanding in modelling climate biosphere feedbacks. Curr. Opin. Environ. Sustain., 3, 311-320, doi:10.1016/j.cosust.2011.08.008, 2011.

Zaehle, S., Friend, A. D., Friedlingstein, P., Dentener, F., Peylin, P., and Schulz, M.: Carbon and nitrogen cycle dynamics in the O$\mathrm{CN}$ land surface model: 2 . Role of the nitrogen cycle in the historical terrestrial carbon balance, Global Biogeochem. Cy., 24, GB1006, doi:10.1029/2009GB003522, 2010a.

Zaehle, S., Friedlingstein, P., and Friend, A. D.: Terrestrial nitrogen feedbacks may accelerate future climate change, Geophys. Res. Lett., 37, L01401, doi:10.1029/2009GL041345, 2010 b.

Zaehle, S., Ciais, P., Friend, A. D., and Prieur, V.: Carbon benefits of anthropogenic reactive nitrogen offset by nitrous oxide emissions, Nat. Geosci., 4, 601-605, doi:10.1038/ngeo1207, 2011.

Zaehle, S., Medlyn, B. E., De Kauwe, M. G., Walker, A. P., Dietze, M. C., Hickler, T., Luo, Y., Wang, Y.-P., El-Masri, B., Thornton, P., Jain, A., Wang, E., Parton, W., Iverson, C. M., GalletBudynek, A., McCarthy, H., Finzi, A., Hanson, P. J., Prentice, I. C., Oren, R., and Norby, R. J.: Evaluation of 11 terrestrial carbonnitrogen cycle models against observations from two temperate Free-Air $\mathrm{CO}_{2}$ Enrichment studies, New Phytol., 202, 803-822, doi:10.1111/nph.12697, 2014.
Zamora, L. M., Prospero, J. M., and Hansell, D. A.: Organic nitrogen in aerosols and precipitation at Barbados and Miami: Implications regarding sources, transport and deposition to the western subtropical North Atlantic, J. Geophys. Res.-Atmos., 116, D20309, doi:10.1029/2011JD015660, 2011.

Zhang, Q., Anatasio, C., and Jimenez-Cruz, M.: Water-soluble organic nitrogen in atmospheric fine particles $\left(\mathrm{PM}_{2.5}\right)$ from northern California, J. Geophys. Res., 107, D11, doi:10.1029/2001JD000870, 2002.

Zhang, Y., Song, L., Liu, X. J., Li, W. Q., Lu, S. H., Zheng, L. X., Bai, Z. C., Cai, G. Y., and Zhang, F. S.: Atmospheric organic nitrogen deposition in China, Atmos. Environ., 46, 195204, doi:10.1016/j.atmosenv.2011.09.080, 2012.

Zhao, Y., Hallar, A. G., and Mazzoleni, L. R.: Atmospheric organic matter in clouds: exact masses and molecular formula identification using ultrahigh-resolution FT-ICR mass spectrometry, Atmos. Chem. Phys., 13, 12343-12362, doi:10.5194/acp13-12343-2013, 2013.

Zhuang, Q., Lu, Y., and Chen, M.: An inventory of global $\mathrm{N}_{2} \mathrm{O}$ emissions from the soils of natural terrestrial ecosystems, Atmos. Environ., 47, 66-75, doi:10.1016/j.atmosenv.2011.11.036, 2012.

Zumft, W. G.: Cell biology and molecular basis of denitrification, Micobiol. Mol. Biol. R., 61, 533-616, 1997. 